Iron-Ore Resources of

\title{
the United States
}

\section{Including Alaska and}

\section{Puerto Rico, 1955}

By MARTHA S. CARR and CARL E. DUTTON

; CONTRIBUTIONS TO ECONOMIC GEOLOGY

n

GE OLOGICAL SURVEY BULLETIN 1082 -C

$A$ survey of iron-ore resources of the United States, with selected bibliography and tables of iron-ore reserves and potential ore

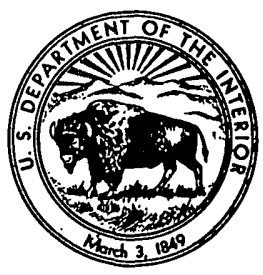


UNITED STATES DEPARTMENT OF THE INTERIOR

FRED A. SEATON, Secretary

GEOLOGIGAL SURVEY

$\boldsymbol{\alpha}$

Thomas B. Nolan, Director

For sale by the Superintendent of Documents, U.S. Government Printing Office Washington 25, D.C. - Price 30 cents

(paper.cover) 


\section{CONTENTS}

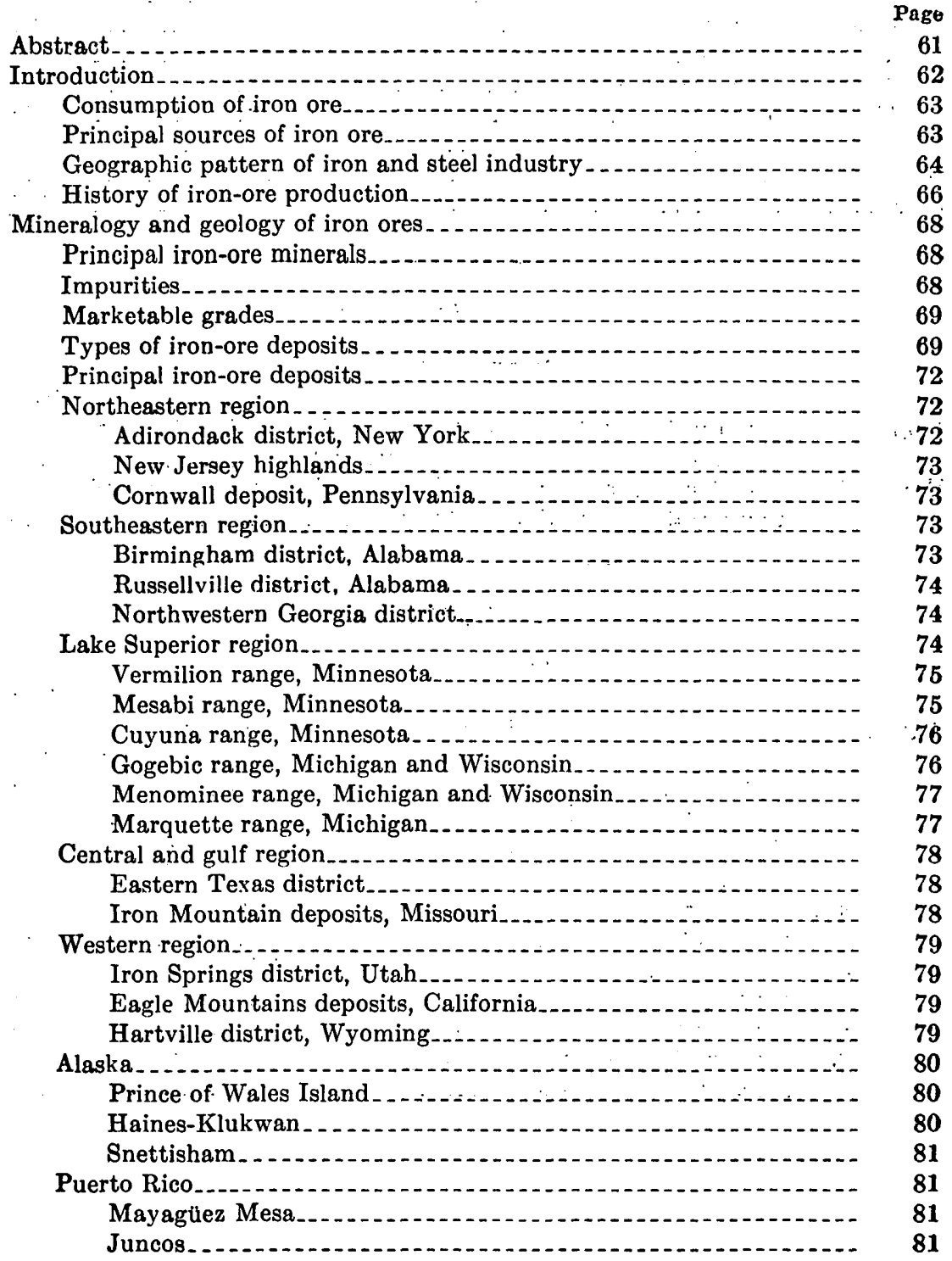


Mining and beneficiation 81

Relation of mining to geology

Types of commercial ore.

Methods and products of beneficiation

Change in chemical composition

Change in physical condition 83

Taconite beneficiation._. 83

Iron-ore reserves and potential ore 84

Classification and terminology

Factors in resource appraisal

Tabulation of iron-ore resources. 85

Selected bibliography _._. 110

Geographic index to selected bibliography 127

Index. 132

\section{ILLUSTRATIONS}

Prate 2. Map of the United States, including Alaska and Puerto Rico, showing the distribution of iron deposits ............ In pocket

Fraure 7. Production and consumption of direct-shipping iron ore and concentrates in the United States....

\section{TABLES}

TABLE 1. Production of direct-shipping iron ore and concentrates, 195155 , and estimated iron-ore resources, by regions, 1955, in the United States.

2. Approximate chemical composition, in percent, of direct-shipping ore and concentrates in the United States, by regions, 1955

Page

2

3

7




\title{
IRON-ORE RESOURCES OF THE UNITED STATES, INCLUDING ALASKA AND PUERTO RICO, 1955
}

\author{
By Martha S. Carr and Card E. Dutton \\ ABSTRACT
}

The importance of iron ore, the basic raw material of steel, as a fundamental mineral resource is shown by the fact that about 100 million long tons of steel is used annually in the economy of the United States, as compared with a combined total of about 5 million long tons of copper, lead, zinc, and aluminum. Satisfying this annual demand for steel requires about 110 million tons of iron ore and $\mathbf{7 0}$ million tons of scrap iron and steel.

The average annual consumption of iron ore in the United States from 1951 to 1955 , inclusive, was about 110 million long tons, which is about twice the annual average from 1900 to 1930 . Production of iron ore in the United States in this 5-year period averaged approximately 100 million long tons annually, divided by regions as follows (in percent) : Lake Superior, 84.1; southeastern, 6.7 ; western, 6.7 ; northeastern, 1.4 ; and central and gulf, 1.1 .

Mining of iron ore began in the American Colonies about 1619, and for 225 years it was limited to eastern United States where fuel and markets were readily available. Production of iron ore from the Lake Superior region began in 1846; the region became the leading domestic source by 1890 , and the Mesabi range in Minnesota has been the world's most productive area since 1896. Proximity of raw materials, water transportation, and markets has resulted in centralization of the country's iron and steel industry in the lower Great Lakes area. Increased imports of iron ore being delivered to eastern United States as well as demands for steel in nearby markets have given impetus to expansion in the steel-making capacity in this area.

The four chief iron-ore minerals-hematite, liminite, magnetite, and siderite-are widely distributed but only locally form deposits of sufficient tonnage and grade to be commercially valuable at the present time. The iron content of these minerals, of which hematite is the most important, ranges from 48 percent in siderite to 72 percent in magnetite, but as these minerals are associated with other rock-forming minerals, the iron content of marketable ore has a lower range-from 30 to 67 percent.

Chemical constituents other than iron also are important in determining the marketability of iron ore. Although some iron ores can be used in the blast furnace as mined, others must first be improved either chemically by reduction of undesirable constituents, or physically by aggregation. Phosphorus and sulfur 
particularly are common deleterious elements; excessive silica is also undesirable but within certain limits can be controlled by additional flux. Lime and magnesia are beneficial in specified amounts because of their fluxing qualities, and a small amount of alumina improves the fluidity of slag. Manganese is especially desirable as a deoxidizing and desulfurizing agent. Titanium, chromium, and nickel must also be considered in the use of ore containing these elements.

The principal iron-ore deposits in the United States have been formed by three processes. Hematite-bearing bedded deposits such as those at Birmingham, Ala., are marine sedimentary rocks which, except for weathering along the outcrop, have remained practically unaltered since deposition. Deposits of the Lake Superior region, also in sedimentary strata, originally had a slightly lower iron content than those at.Birmingham, but ore bodies of hematite and limonite were formed by removal of other constituents in solution after deposition of the beds; with a relative increase of iron content in the material remaining. Limestone adjacent to igneous intrusions has been replaced by magnetite depasits at Cornwall, Pa., and by hematite-magnetite deposits near Cedar City, Utah. Magnetite deposits in New Jersey and in the Adirondack Mountains of New York are generally believed to have been formed by replacement of grains of other minerals in metamorphic rocks.

Iron-ore resources are made up of reserves of iron ore, material usable under existing economic and technologic conditions; and potential ore, material likely to become usable under more favorable conditions. The tonnage and grade of material of combined reserves and potential ore in each of the deposits known or believed to contain at least 200,000 long tons of iron-ore resources are tabulated in this report, and numerous sources of additional information are given in a selected bibliography.

The total domestic iron-ore resources are estimated at approximately $\mathbf{7 5 , 0 0 0}$ million long tons of crude ore. About 10,000 million tons of the resources is reserves of crude ore that will probably yield 5,500 million tons of concentrates and direct-shipping ore. About 65,000 million tons is potential ore and may yield 25,000 million tons of concentrates and some direct-shipping ore.

\section{INTRODUCTION}

Iron ore is a fundamental mineral resource from which iron is extracted to make steel for numerous uses in nearly all phases of the present economy. The importance of iron ore is emphasized by the fact that approximately 100 million long tons of steel is consumed annually in the United States, as compared with a total consumption of about 5 million long tons of copper, lead, zinc, and aluminum. Continued or increased demands for steel can be satisfied only by further mining and consequent depletion of nonrenewable iron-bearing material in the earth. Percentage of depletion is a relative matter, however, and must be appraised by considering that exploration has discovered only part of the total potential supply of ironbearing material, and that advances in beneficiation are significantly increasing the proportion of the total supply that is suitable for steel making.

The purpose of this report is to summarize available information 
concerning iron-ore resources in the United States in order to provide a general background for understanding and appraising the present status of this basic commodity. Iron-ore resources include reserves, material usable under existing economic and technologic conditions; and potential ore, material likely to become usable under more favorable conditions. Reserves are made up of both direct-shipping ore, which is of usable grade as mined, and concentrates, which are obtained by various methods of beneficiation.

For ease of description in this report, iron deposits in continental United States are grouped geographically into five regions, as shown below. Alaska, which became a State after this report was prepared, and Puerto Rico are discussed after the regional descriptions.

$\begin{array}{lllll}\text { Northeastern } & \text { Southeastern } & \text { Lake Superior } & \text { Central and gulf } & \text { Western } \\ \text { Connecticut } & \text { Alabama } & \text { Michigan } & \text { Arkansas } & \text { Arizona } \\ \text { Maine } & \text { Delaware } & \text { Minnesota } & \text { Illinois } & \text { California } \\ \text { Massachusetts } & \text { Florida } & \text { Wisconsin } & \text { Indiana } & \text { Colorado } \\ \text { New Hanpshire } & \text { Georgia } & & \text { Iowa } & \text { Idaho } \\ \text { New Jersey } & \text { Kentucky } & & \text { Kansas } & \text { Montana } \\ \text { New York } & \text { Maryland } & \text { Louisiana : } & \text { Nevada } \\ \text { Ohio } & \text { Mississippi } & \text { Missouri } & \text { New Mexico } \\ \text { Pennsylvania } & \text { North Carolina } & \text { Nebraska } & \text { Oregon } \\ \text { Rhode Island } & \text { South Carolina } & \text { North Dakota } & \text { Utah } \\ \text { Vermont } & \text { Tennessee } & \text { Oklahoma } & \text { Washington } \\ & \text { Virginia } & & \text { South Dakota } & \text { Wyoming } \\ & \text { West Virginia } & & \text { Texas } & \end{array}$

\section{CONSUMPTION OF IRON ORE}

An average of 110 million long tons of iron ore and 70 million tons of scrap iron and steel are required annually to meet the demand for steel production in the United States. The amount of iron ore consumed has generally increased since the beginning of the industry, and reached 125 million long tons for the year 1955 (fig. 7). The average annual consumption from 1900 to 1930 was about 55 million tons, from 1940 to 1950 about 95 million tons, and from 1951 to 1955, inclusive, about 110 million tons. The current rate of consumption is thus more than double the rate from 1900 to 1930, and further increases will be needed to provide ore for expansion of furnace capacity. Although domestic production of large amounts of highgrade ore will continue, the need for increased supplies of iron ore will be met by using more concentrates from lower grade ore and by. importing more ore.

\section{PRINCIPAI SOURCES OF IRON ORE}

The principal sources of iron ore in the United States are widely distributed, as shown on plate 2. The trend in production of directshipping iron ore and concentrates in the United States, by regions, 


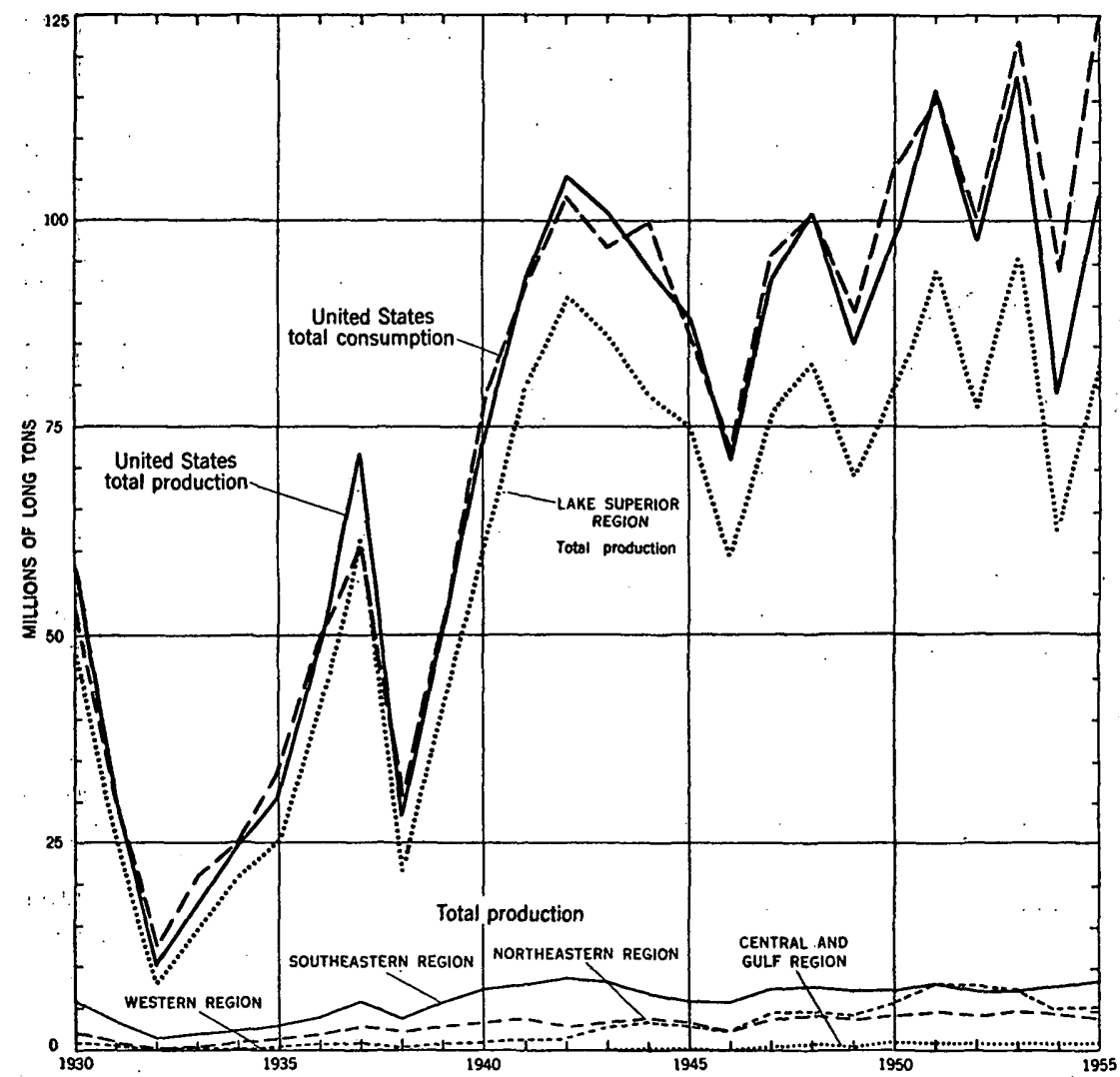

Frover 7.-Production and consumption of direct-shipping iron ore and concentrates in the United States, in millions of long tons.

for the period 1930-55 is illustrated in figure 7. Production, reserves, and potential ore, by regions, are shown in table 1 . In general the reserves are roughly proportionate to production. The western region and central and gulf region seem seriously deficient in potential ore to maintain their present relative production rates, but data for iron-ore resources in these regions are probably less complete or more conservatively interpreted than for other regions, which have been the principal sources of iron ore for many years. The Lake Superior and southeastern regions have the major share of reserves (84.6 percent) and potential ore (94.6 percent) and presumably will continue to produce the bulk (90.8 percent, 1951-55) of domestic iron ore.

\section{GEOGRAPHIC PATTERN OF IRON AND STEEL INDUSTRY}

Quantity and quality of ore are foremost considerations in iron-ore economics, but additional factors that determine the geographic pattern of the iron and steel industry are adequate supplies of fuel and 
TABLE 1.-Production of direct-8hipping iron ore and concentrate8, 1951-55, and estimated iron-ore resources, by regions, 1955, in the United States

\begin{tabular}{|c|c|c|c|c|c|c|}
\hline \multirow{3}{*}{ Region - } & \multicolumn{2}{|c|}{ Production 1} & \multicolumn{4}{|c|}{ Resources (estimated tonnage) } \\
\hline & \multirow{2}{*}{$\begin{array}{c}\text { Millions } \\
\text { of long } \\
\text { tons }\end{array}$} & \multirow{2}{*}{$\begin{array}{l}\text { Percent- } \\
\text { age of } \\
\text { total }\end{array}$} & \multicolumn{2}{|c|}{ Reserves ${ }^{2}$} & \multicolumn{2}{|c|}{ Potential ore 8} \\
\hline & & & $\begin{array}{l}\text { Millions of } \\
\text { long tons }\end{array}$ & $\begin{array}{c}\text { Percent- } \\
\text { age of } \\
\text { total }\end{array}$ & $\begin{array}{l}\text { Millions of } \\
\text { long tons }\end{array}$ & $\begin{array}{l}\text { Percont- } \\
\text { age of } \\
\text { total }\end{array}$ \\
\hline $\begin{array}{l}\text { Northeastern } \\
\text { Southeastern } \\
\text { Lake Superior } \\
\text { Central and guif: } \\
\text { Western }\end{array}$ & $\begin{array}{r}6.70 \\
32.64 \\
405.56 \\
5.25 \\
32.22\end{array}$ & $\begin{array}{r}1.4 \\
6.7 \\
84.1 \\
1.1 \\
6.7\end{array}$ & $\begin{array}{r}300 \\
610 \\
4,000 \\
50 \\
490\end{array}$ & $\begin{array}{r}5.5 \\
11.2 \\
73.4 \\
.9 \\
9.0\end{array}$ & $\begin{array}{r}2,850 \\
11,220 \\
50,000 \\
116 \\
500\end{array}$ & $\begin{array}{r}4.4 \\
17.3 \\
77.3 \\
.2 \\
.8\end{array}$ \\
\hline Total & 482.37 & 100.0 & About 5,500 & 100.0 & About 65,000 & 100.0 \\
\hline
\end{tabular}

1 Production figures from U.8. Bureau of Mines.

2 Direct-shipping ore and concentrates usable under present technologic and economic conditions.

8 Probably usable, partly as direct-shipping ore but mostly after beneficiation, under more favorable technologic and economic conditions.

flux, markets for finished products, and favorable transportation costs.

Common practice in smelting has required a mixture of iron ore and solid fuel, which was first charcoal, later was coal, and now is coke. The large quantities of coal needed for smelting determined the early establishment of smelting centers in or near coal-producing areas such as Pittsburgh, Pa., Birmingham, Ala., and later at Pueblo, Colo., and near Provo, Utah, as markets developed with westward migration and settlement.

The change from coal to coke and the increased efficiency of furnaces, which has lowered the ratio of solid fuel to iron ore, have permitted some changes in the customary pattern of shipping iron ore to sources of coking coal. The principal factors that have determined these changes have been costs of transporting raw materials and finished products. The much lower cost of transportation by water than by rail, combined with ready access to markets for finished products, has been responsible for development of smelting centers near Detroit, Chicago, Trenton, and Baltimore. The great production of iron ore from the Lake Superior region, the low-cost transportation on the Great Lakes, and the large supplies of coal from Pennsylvania, West Virginia, and Kentucky have brought about the centralization of approximately 75 percent of the country's iron and steel industry, as of 1955, in the lower Great Lakes area-between Pittsburgh and Buffalo on the east and Chicago on the west.

Steel manufacturing has also developed in some localities without the advantage of low-cost transportation by water or proximity to coking coal. Steel for the market area served from Provo, Utah, is made of iron ore shipped from the southwestern part of the State and coking coal from northeastern Utah and south-central Colorado. Iron 
ore from the Eagle Mountains in southeastern California and coal from Utah are raw materials for steel made near Los Angeles for the adjacent market area. Increased amounts of imported iron ore arriving on the eastern seaboard of the United States and demands for steel in nearby markets have prompted growth of steel-making capacity in this area. The amount of iron ore received at Atlantic and Gulf of Mexico ports in 1950 was about 6.5 million tons, which was 6 percent of the total domestic consumption of iron ore for that year, and the amount in 1956 was about 30 million tons or almost 14 percent. The principal related development in the making and fabrication of steel has been the building of a 6.2 million net-ton steel plant at Sparrows Point, Md., and a 2.2 million ingot-ton mill at Morrisville, Pa., across the Delaware River from Trenton, N.J.

\section{HISTORY OF IRON-ORE PRODUCTION}

Mining and smelting of iron ore in the Colonies that later formed the United States of America began in Virginia at least as early as 1619 , and in the Now England area a few decades later. These operations were locally important but had limited capacity and potentiality because they were dependent upon small supplies of iron ore in nearby bogs and upon use of charcoal for fuel.

Deposits of iron ore in southeastern New York, northern New Jersey, and eastern Pennsylvania, which were being mined by 1750 , were conducive to a moderate expansion of the iron industry because they were much more extensive than bog ores.

The next important expansion began about 1820 when coal of the Appalachian area was used for making coke, which replaced charcoal and coal in smelting operations. This change facilitated a greatly increased output of iron to meet the expanding needs of transportation, commerce, and agriculture that accompanied the westward movement of settlers.

In several respects the latter half of the 19th century was the most important period in the history of iron-ore production in the United States. Iron ore in the Birmingham district, Alabama, was first smelted in blast furnaces about 1865, with bituminous coal; the use of coke began about a decade later. The major events in this half century were, however, the exploration and development of the deposits in the Lake Superior region, including the beginning of production from the Mesabi range in 1892.

Iron-ore production in the United States since 1900 has increased persistently, though with fluctuations related to economic cycles and wars. A small but locally important part of the increased output since 1943, during the Second World War, has come with the initia- 
tion or expansion of production from deposits in the central and gulf region and the western region.

The northeastern region had furnished a little more than 200 million tons of iron ore through 1955; production from New York was about 50 percent of the total, Pennsylvania 30 percent, and New Jersey 20 percent. The earliest mining of iron ore in this region was probably in New Jersey in 1685; the Dover district, which is the principal area of production, has been mined since 1710. The Cornwall mine in southeastern Pennsylvania, which began producing in 1740 , is the oldest continuously operating mine in the United States and has been the principal producer in the State. The Adirondack district has been the chief spurce of iron ore from New York, where deposits have been mined since 1775 .

The total production of iron ore in the southeastern region through 1955 was probably about 350 million tons, 80 percent of which has come from the Birmingham district, Alabama, where mining possibly began before 1818 .

Slightly more than 3,000 million tons of iron ore had been shipped through 1955 from the part of the Lake Superior region that is in the United States. Approximately two-thirds of the total came from the Mesabi range, Minnesota; the Vermilion and Cuyuna ranges, also in Minnesota, have produced 6 percent of the regional total. The earliest mining in this region was in 1846 in the Marquette range; Michigan; total production of all ranges in this State has been about 25 percent of the total for the region. Mining in the Wisconsin part of the region began in 1884 and has provided 2 percent of the regional total:

Total iron-ore production in the central and gulf region through 1955 was slightly less than 30 million tons. Mining of iron ore began in Missouri in 1845 and has produced almost two-thirds of the regional total; the other third has been produced in Texas since 1855 .

Iron ore produced in the western region totaled slightly more than 70 million tons through 1955 , mostly from 3 States. Mining of iron ore in Wyoming began in 1868 and has provided a little more than 20 million tons. Iron ore in Utah was first mined in 1874, but 85 percent of a total production of almost 40 million tons has been mined since 1942. The earliest mining of iron ore in California was 1881, but most production has also been since 1942 and has totaled a little more than 10 million tons.

The total production of direct-shipping iron ore and concentrates in the United States, through 1955, was 3,650 million long tons, derived in percentage by regions as follows: Lake Superior, 82.19; southeastern, 9.59 ; northeastern, 5.48; western, 1.92 ; and central and gulf, 0.82 (chart $B$ on pl. 2, in pocket). 


\section{MINERALOGY AND GEOLOGY OF IRON ORES}

\section{PRINCIPAI IRON-ORE MINERAIS}

Iron, a common chemical element, is fourth in order of abundance in the earth's crust and constitutes approximately 5 percent of it. This element seldom occurs in the native, or metallic, state but is generally combined with other elements in a great variety of minerals: Metallic iron can be economically extracted at the present time, however, from only a few of these compounds or iron-bearing minerals (see table below).

Composition of the principal iron-ore minerals

\begin{tabular}{|c|c|c|c|c|c|}
\hline \multirow{2}{*}{ Mineral and commercial name } & \multirow{2}{*}{$\begin{array}{l}\text { Chemical } \\
\text { formula }\end{array}$} & \multicolumn{4}{|c|}{ Composition (percent) } \\
\hline & & Iron & Oxygen & Carbon & Water \\
\hline $\begin{array}{l}\text { Magnetite (magnetic ore) } \\
\text { Hematite (red or gray ore) } \\
\text { Limonite (brown ore) } \\
\text { Siderite (carbonate ore) }\end{array}$ & $\begin{array}{l}\mathrm{Fe}_{3} \mathrm{O}_{4} \\
\mathrm{Fe}_{2} \mathrm{O}_{3} \\
(\stackrel{1}{)} \\
\mathrm{FeCO}_{3}\end{array}$ & $\begin{array}{l}\text { 72. } 4 \\
69.9 \\
60.0 \\
48.3\end{array}$ & $\begin{array}{l}27.6 \\
30.1 \\
26.0 \\
41.4\end{array}$ & $\begin{array}{c}0 \\
0 \\
0 \\
10.3\end{array}$ & $\begin{array}{c}0 \\
0 \\
14.0 \\
0\end{array}$ \\
\hline
\end{tabular}

1 Limonite is a variable mixture of hydrated iron oxides, mostly goethite-FeO(OH); the composition given in this table is average.

The iron-ore minerals are most readily distinguished from each other by color, as indicated by the commercial names "red or gray ore" and "brown ore" for ore composed of hematite and limonite, respectively; all magnetite is black, and most siderite is gray. Specular hematite, which only locally constitutes important parts of domestic iron-ore deposits, comprises black plates or scales with brilliant metallic luster that are red when pulverized or scratched. Magnetite is generally of octahedral form when not massive, and siderite of rhombohedral form; hematite and limonite are commonly so finely granular as to be of earthy appearance. Magnetite is further characterized by being attracted by a magnet, and some specimens are themselves magnetic (lodestone).

The chief minerals in ores now being mined are hematite, limonite, and magnetite; hematite is the most widely distributed and important. Siderite is currently being produced in east Texas, but in general it is of interest principally because of its alteration, in many places, to limonite.

Because most iron deposits contain other minerals and host rock, the ores are slightly to considerably lower grade than the ore minerals themselves.

\section{IMPURITIES}

The chemical constituents of minerals associated with iron-ore minerals are commonly designated as oxides-silica, alumina; lime, 
and magnesia; or as elements-sulfur, phosphorus, manganese, titanium, chromium, and nickel. Some of these constituents, which in general are referred to as impurities, have deleterious effects whereas others are beneficial. Phosphorus and sulfur are deleterious and must be reduced to acceptable amounts in smelting operations; they consequently determine to a large degree the marketability of the ores. Although some silica in ore is needed to form slag, which separates to a certain degree associated impurities from molten iron during smelting, excessive silica must also be removed. This may be done either by mill treatment:before smelting or by proportionally increasing the flux in the blast furnace. Lime and magnesia are desirable within certain limits for their fluxing qualities; and alumina, also in restricted amount, is desirable because it improves fluidity of the slag. Manganese has a strong affinity for oxygen and sulfur and is desirable for removing these elements from the steel, as well as for adding toughness to it. Titanium in excessive amounts may cause accretion in the furnace and is objectionable unless sufficiently abundant to justify its recovery as a byproduct from slag. Chromium and nickel are also generally undesirable in iron ore, although some ore containing these elements has been used in the manufacture of steel for special purposes.

\section{MARKETABLE GRADES}

The range in percentage of the principal constituents of marketable iron ores and concentrates, by regions, is given in table 2. Depending largely upon local conditions, ore containing greater or lesser amounts of the constituents shown in the table can be mined. Improvements in beneficiation methods and metallurgical processes may increase the range.

\section{TYPES OF IRON-ORE DEPOSITS}

The term "iron deposit" is used in this report in a very general geologic sense for masses in which iron-ore minerals are abundant; the occurrences may or may not be commercially valuable at the present time. "Iron ore" and "iron-ore deposit" refer to occurrences that are, may be, or are believed to be, sources from which metallic iron can be obtained profitably at the present time. No single term seems especially appropriate to designate the great variety of noncommercial occurrences.

Iron-ore deposits and, generally, much associated lower grade material have been formed by a variety of geologic processes and combinations of processes, but three general types of deposit are most significant. These are bedded, replacement and vein, and residual. 


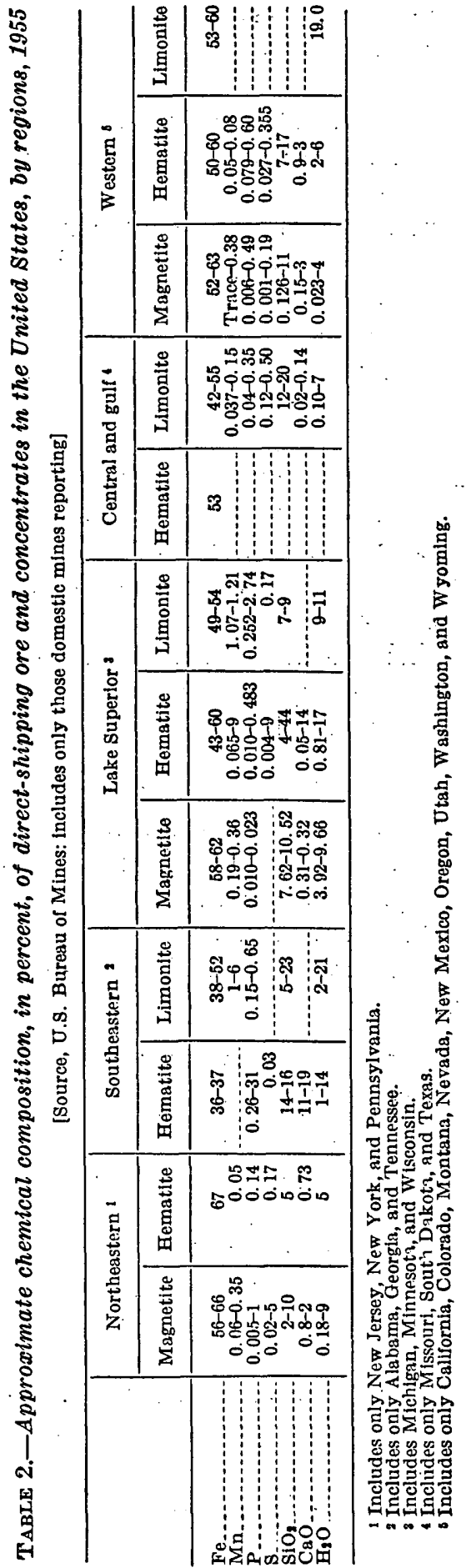


Bedded iron deposits are sedimentary layers that accumulated by precipitation of iron compounds in bodies of water. The deposition was in bogs, lakes, or seas; and the iron deposits are associated with the normal sequences of strata formed in those environments. Bedded iron deposits are generally very extensive, but only a part of the material is ore. Examples of bedded iron deposits in the United States are (a) taconite or unenriched iron-formation in the Lake Superior region; (b) iron-formation of Clinton type in eastern and southeastern United States, especially the Birmingham district, Alabama; and (c) sideritic beds in Pennsylvania and Ohio.

Iron deposits of the replacement and vein type are massive or tabular bodies of iron-ore minerals that have taken the place of preexisting rock-forming minerals or have filled voids in the rock, especially openings along fractures. Constituents to form the iron-ore minerals were presumably derived from magmatic sources in the hydrothermal variety of replacement and vein deposits and from products of rock weathering transported by ground water in the surficial variety. Examples of replacement and vein deposits of hydrothermal origin are the iron ores at Cornwall, Pa.; in the Iron Springs district, Utah; in northern New Jersey; and several ore deposits in the Adirondack district of New York. Replacement, vein, and cavity-filling deposits of surficial variety are the limonitic ore of the Russellville district, Alabama, and in part the sideritic and limonitic ore of eastern Texas.

Residual iron deposits have formed by decomposition of a: wide variety of rocks whose original iron content has been relatively increased by removal of nonferrous constituents. The deposits are hematite or limonite or both that were originally in the rock or were formed from iron-bearing carbonate or silicates. The principal residual iron-ore deposits have formed from lower grade bedded deposits and consequently have similar characteristics. Other residual deposits of iron ore are commonly of very irregular form and are less extensive. Examples of residual deposits in the United States are the high-grade ores of the Lake. Superior region and probably most of the limonitic ore of eastern Texas.

Iron deposits have probably also formed as segregations in igneous rocks by separation and concentration of magnetite and hematite during crystallization of the molten mass. Many geologic features of segregation deposits are similar to those of replacement deposits; and positive distinction between these types may be difficult: The magnetite-bearing masses at Lake Sanford, N.Y., are generally classified as segregation deposits. 


\section{PRINCIPAL IRON-ORE DEPOSITS}

Descriptions of the principal sources of iron ore are included not only for general information as to the physical features of the deposits but also because geologic occurrence is the basis for inferences as to probable shape; size, position, and quality of deposits. The summation of geologic occurrences in the United States and the related interpretations indicate the probability of little or no significant change from the existing situation in which the iron-ore resources in extensive bedded deposits of the Lake Superior and southeastern regions are many times greater than those in the irregular replacement deposits that predominate in other regions.

\section{NORTHEASTERN REGION}

The principal deposits of iron ore in the northeastern region are magnetite-bearing masses of the Adirondack district in northern New York, of the highlands in northern New Jersey, and of the Cornwall mine in southeastern Pennsylvania. Most of the mining is underground, and most of the mined material requires beneficiation.

Deposits of hematite (except where associated with magnetite and mentioned below), limonite, and siderite are not of great significance in the northeastern region.

\section{ADIRONDACK DISTRICT, NEW YORK}

The most productive iron-ore deposits of the northeastern region are the magnetite bodies of the Adirondack district. These deposits are gently to steeply inclined tabular to lenticular masses whose shape and orientation conform to the structure of the enclosing Precambrian gneiss and schist. The principal deposits are at Lyon Mountain in the northeastern part of the Adirondack district, MinevillePort Henry in the southeastern part, and the Benson mines in the western part. The main ore bodies at Lyon Mountain range in length from 700 to 4,500 feet and in thickness from 3 to 27 feet, with slope depths of as much as 2,350 feet. The Mineville-Port Henry bodies appear to be folded and faulted parts of a lens-shaped mass that was originally about 1 mile long and had an average thickness of about 100 feet. The main ore body at Benson mines is a slightly concave mass about 2 miles long, a mile wide, and about 200 feet thick; it contains both magnetite and hematite. At Lake Sanford in the southern part of the district several magnetite- and ilmenitebearing bodies occur in gabbro and anorthosite. The largest deposit, Sanford Hill, is at least 1,800 feet long and 600 feet wide; 2 principal lenses of ore are, respectively, 800 and 1,000 feet long, 300 and 400 feet wide, and 150 and 550 feet deep. Mining at Benson mines and at Lake Sanford is by open-pit methods. 


\section{NEW JERSEY HIGHLANDS}

The magnetite deposits in the highlands of northern New Jersey are moderately to steeply dipping tabular or lathlike bodies that parallel the structure of the enclosing Precambrian rocks. The ore bodies are replacements principally of gneiss but to a lesser extent of skarn and marble.

The Dover district contains the largest known magnetite deposits in the highlands. Massive ore occurs in gneiss and skarn, and disseminated ore in granite. Hematite constitutes about 15 percent of the disseminated ore. Ore bodies range from 5 to 20 feet in thickness and from 100 to 2,400 feet in breadth; several have been mined for more than 8,000 feet along the plunge.

\section{CORNWALL DEPOSIT, PENNSYLVANIA}

At Cornwall, 6 miles south of Lebanon, Pa., 2 major lenticular ore bodies of magnetite and hematite replace Cambrian limestone adjacent to intrusive diabase of Triassic age. The first one discovered was a mile long, ranged in width from a few feet to as much as 500 feet, and extended to a depth of 400 feet. This ore body dips steeply and is mined by both open-pit and underground methods; the other ore body is mined only by underground methods. Chalcopyrite containing small percentages of gold and silver, and pyrite containing 1.25 percent cobalt, are recovered as byproducts.

Magnetite of the Cornwall type is present in other localities in Pennsylvania, including the Grace mine and the Boyertown area in Berks County and an area near Dillsburg in York County.

\section{SOUTHEASTERN REGION}

Many iron-ore deposits in the southeastern region have been worked, but the Birmingham district, Alabama, ranks first in resources and production of hematite. The Russellville district, Alabama, and northwestern Georgia are the principal producers of limonite. Additional deposits of hematite, limonite, and some magnetite are common in the Appalachian area, from Maryland and the Virginias on the northeast to central Alabama on the southwest.

\section{BIRMINGHAM DISTRICT, ALABAMA}

The chief iron-ore area in the southeastern region is the Birmingham district in central Alabama, which ranks next to the Mesabi in ore reserves. The district is about 75 miles long by 40 miles wide.

The principal ore is composed of oolitic hematite that occurs in extensive bedded deposits of the Red Mountain formation, of Silurian age. Four ore beds, or seams, are interstratified with shale and sand500116-59-3 
stone. The Big Seam, which is the principal source of ore at present, crops out for about 20 miles and is relatively uniform in composition and thickness. Although the bed is 16 to 30 feet thick, only 10 to 12 feet of good ore is generally present.

The ore beds are mined by underground methods, and, because of the simple geologic structure, extensive mining is possible. The beds in the mining area dip $15^{\circ}-45^{\circ}$. The ore contains 35 to 39 percent iron, 18 to 23 percent calcium carbonate, and 17 to 29 percent silica: Some ore is treated to reduce the silica content, but ore with a high lime content is self-fluxing and can be used as mined.

\section{RUSSELLVILIL DISTRICT, ALABAMA}

The ore of the Russellville district in northwestern Alabama consists of limonitic concentrations in various forms. The deposits are relatively small lenses or irregular masses underlying hundreds of acres, and range from a few feet to as much as 100 feet or more in thickness. Some deposits occur near the tops of hills on irregular surfaces of Bangor limestone of Mississippian age, or in the clay residue from it. Other deposits occur as fragments, cementing material, and cavity fillings in basal conglomerate and loose gravel that are generally considered to be of Tertiary age. The ore is washed to remove associated gravel and sand.

\section{NORTHWESTERN GEORGIA DISTRICT}

The most important limonitic ore deposits in northwestern Georgia are in the belt of Paleozoic strata that extends northeastward across the corner of the State. The ore occurs chiefly as irregular masses in residual clay formed from the weathering mainly of calcareous rocks and locally of quartzite. The deposits range in size from small accumulations of nodules in clay to ore bodies 50 to 150 feet or more in thickness underlying hundreds of acres. Although the host rocks of the deposits are of Cambrian and Ordovician age, the concentration into deposits of commercial ore is considered to have occurred in Tertiary time:

\section{IAKE SUPERIOR REGION}

The principal iron-ore deposits of Minnesota, Wisconsin, and Michigan are situated in long, comparatively narrow areas, called ranges, in the general vicinity of Lake Superior. The six principal iron ranges are the Vermilion, Mesabi, and Cuyuna in Minnesota, the: Gogebic and Menominee in Wisconsin and Michigan, and the Marquette in Michigan.

The deposits are in iron-formation of Precambrian age. The ironformation is bedded rock that consists of alternating iron-rich and 
silica-rich layers which are composed of varying proportions of iron oxide, iron carbonate, iron silicates, and chert or fine-grained quartz: The ore bodies in the iron-formation have been formed principally by oxidation of iron carbonate and iron silicate with simultaneous or subsequent leaching of silica that further concentrated the iron oxide. Ore bodies have originated also from the replacement of silica by iron and possibly from concentration of iron by normal sedimentation processes.

The Lake Superior region was previously covered by glaciers and has a discontinuous mantle of drift that is as much as several hundred feet thick. Wherever possible, the iron deposits are stripped of this glacial cover and then mined by open-pit methods. As the strata of the Mesabi range are only slightly inclined and the beds are of great horizontal extent, most of the ore is produced from open pits. Strata in the other ranges are steeply inclined, and most of the mines are underground, although in the Cuyuna range open pits predominate.

The iron ore in the Lake Superior region is mainly hematite and limonite, but some is magnetite. The iron-bearing material is classified as (a) direct-shipping ore, which can be shipped to the furnaces as mined; (b) intermediate ore, which can be beneficiated by rather simple processes; and (c) taconite-or unenriched iron-formation. Production of concentrates containing 63 to 65 percent iron from the very large tonnages of the Mesabi's magnetic taconite and from nonmagnetic iron-formation of the Marquette range is progressively increasing.

\section{VERMILION RANGE, MINNESOTA}

The Vermilion range is in northeastern Minnesota where iron-formation, which may be several hundred feet thick, underlies 2 areas of iron ore that are about 25 miles apart. These areas are approximately 5 miles long and half a mile wide. The ore is hard, dense hematite of high grade and is in lenticular to tabular bodies enclosed in steeply inclined iron-formation and interbedded greenstone of the Keewatin series (early Precambrian). Some of the large ore bodies are 1,500 feet long, and about 100 feet wide and extend downward 2,500 feet vertically. Geophysical work in 1950 indicated that an extension of the Vermilion range curves southeastward from Soudan, Minn.

\section{MESABI RANGE, MINNESOTA}

The Mesabi range, which extends for 110 miles in northeastern Minnesota, is the largest iron-ore district in the United States. The belt of iron-formation, which lies below glacial drift, averages about $11 \frac{2}{2}$ miles in width of exposure and 400 to 750 feet in thickness. Ore 
bodies range in size from a few acres to an area $31 / 4$ miles long and one-half to 1 mile wide, and is as much as 500 feet thick. Limonite and hematite occur in approximately equal amounts.

The iron-formation in the Mesabi district is called taconite, a name that until recently has been generally restricted to this district. The taconite averages 27 percent iron, which may be present as magnetic or nonmagnetic oxide or as a silicate, and about 50 percent silica, present in the silicates and chert. Magnetic taconite is relatively lean raw material, averaging 22 percent available iron, from which a commercial product is obtained by concentration. The magnetic taconite, of which about 6,000 million long tons can be obtained by openpit mining, has recently become an important source of iron.

\section{CUYUNA RANGE, MINNESOTA}

The Cuyuna range in central Minnesota extends about 65 miles from northeast to southwest; its width ranges from 1 to 12 miles. The district is composed of two parallel parts: the North range, which contains several belts of iron-bearing rocks and includes the main ore deposits, and the South range, which consists of a narrow iron-bearing belt that yielded a small amount of ore from 1913 to 1919 and from 1951 to 1953. The main iron-formation of the Cuyuna is 50 to 400 feet thick and is associated with slate and quartzite. All strata are complexly folded. The bedrock is covered by glacial till or drift that ranges from 20 to 400 feet in thickness; the maximum overburden in the productive area exceeds 200 feet. The ore is limonite and hematite and is generally manganiferous in the North range. Concentrates produced mainly by washing form more than half of the annual shipment of about 3 million tons. The average analysis of shipments from 1945 to 1954 was 43 percent iron and 4 percent manganese. The maximum dimensions of the ore bodies are 2 miles in length and a quarter of a mile in width. Open pits are as much as 350 feet deep, and the only underground mine is 800 feet deep.

\section{GOGEBIC RANGE, MICHIGAN AND WISCONSIN}

The Gogebic range extends about 70 miles southwestward from northwestern Michigan into northern Wisconsin. The iron-formation, which is associated with slate and quartzite, has an exposed width of 800 to 1,000 feet and a thickness of 400 to 1,000 feet. These rocks dip about $60^{\circ} \mathrm{NW}$., are displaced by faults, and are intruded by dikes and sills. The ore is hematite that occurs in steeply inclined tabular bodies and plunging masses along the intersections of dikes and the iron-formation. Maximum dimensions of ore bodies are 3 miles in pitch length, 400 feet in thickness, and 1,500 feet parallel to the dip of inclined strata. At one time some ore was at the bedrock surface; 
at present other masses are being mined at depths of approximately 3,500 feet. Large tonnages of low-grade ore also are present in this area.

\section{MENOMINEE RANGE, MICHIGAN AND WISCONSIN}

The Menominee range lies partly in the south-central part of the Upper Peninsula of Michigan and partly in northeastern Wisconsin. It extends northwestward in a series of disconnected segments over a distance of 50 miles and in places is 15 miles wide. In the eastern part, in southern Dickinson County, Mich., the ore is specular hematite in steeply inclined, faulted iron-formation. The iron-formation is 650 feet thick, but the middle part contains no ore. Before mining was begun, maximum dimensions of the ore, though not combined in any single ore body, were as much as 150 feet by 2,500 feet horizontally, and 2,000 feet vertically. In the western part, in southern Iron County, Mich., the ore is nonspecular hematite and limonite in complexly folded iron-formation. The iron-formation is 200 to 600 feet thick; maximum widths of ore bodies are more than 300 feet. Some ore bodies at one time extended more than $11 / 2$ miles in length and 1,000 feet in depth, others more than 2,000 feet in depth. Northern Florence County, Wis., which lies between these 2 Michigan areas, is geologically similar to Iron County and was previously mined, but it has only 1 recently active mine, a small open pit. Large tonnages of low-grade potential ore also are present in the Menominee range.

\section{MARQUETTE RANGE, MICHIGAN}

The Marquette range, which lies wholly in Michigan, extends westward from the city of Marquette for about 30 miles and is 1 to 6 miles wide. The principal iron-formation of the Marquette district attains a maximum thickness of at least 2,000 feet and lies in a westwardplunging syncline. The most productive part of the district is in the area where the exposed iron-formation crosses the axis of the fold. Tabular masses of ore parallel the stratification of the enclosing rock, cylindrical ones occur along intersections of dikes, and irregular ones rest on sills. Ore bodies, which are as much as 250 feet thick, have been mined to vertical depths of almost 3,000 feet. The ore produced is principally hematite, part of which is premium lump material for use in open-hearth furnaces. The range also contains large tonnages of oxidized iron-formation, known as jaspilite, which is a potential source of iron. Production of concentrates from some of this material began in 1954.

Another iron-formation is as much as 200 feet thick and has been mined along the north side of the basin in the western part of the 
range. The ore bodies are relatively small, shallow, and irregular. Beneficiation of low-grade ore from this formation began in 1952.

\section{CENTRAL AND GULF REGION}

Iron-ore reserves in the central and gulf region are generally smaller than in the other regions. The largest deposits are limonite and siderite ores of the eastern Texas district and specular hematite of Iron Mountain in southeastern Missouri.

\section{EASTERN TEXAS DISTRICT}

Surficial deposits of limonite or brown ore occur over a wide area in eastern and northeastern Texas. Below the weathered zone the limonite grades into siderite, which is also plentiful. The deposits are almost exclusively in greensand (a mixture of glauconitic sand, quartz sand, and clay) that averages about 25 feet in thickness and is of early Tertiary age. The ore occurs in gently dipping strata on flat-topped hills and ridges where thin ferruginous sandstone cappings have protected the underlying material from erosion. The ore is believed to have been derived from iron silicate minerals in greensand, first by alteration to siderite and subsequently by oxidation and hydration to limonite.

The ore beds lie within a shallow structural trough that is divided into North and South basins. The brown ore in the North basin occurs chiefly as abundant nodules and thin lenticular layers in a zone 5 to 30 feet thick in the upper part of the greensand. Siderite, which forms about one-third of the ore in the North basin, is present in similar forms at or near the ground-water level. Most of the workable ore-bearing material underlies areas of several hundred acres, and the largest deposit underlies at least 2,500 acres.

The ore in the South basin occurs almost continuously for many miles along the outcrop as a solid bed of brown laminated or crumbly material which ranges in thickness from a few inches to 3 or 4 feet. The horizontal subsurface extent of the ore is limited to approximately 500 feet from the outcrop. In this basin the rock was formerly glauconitic clay with little or no quartz sand. Siderite is far less plentiful here than in the North basin.

Limonitic and carbonate ores, which are mined by open-pit methods, are washed to remove the sand and gravel. Some of the limonitic ore is dried in kilns after washing, and the carbonate ore, in addition to being dried, is calcined and sintered.

\section{IRON MOUNTAIN DEPOSITS, MISSOURI}

The deposits at Iron Mountain, in southeastern Missouri, contain the principal iron ore in the State. The ore is chiefly massive hard 
specular hematite, which forms replacement masses and veins in andesite porphyry of Precambrian age.

One ore body at this locality is a vein several hundred feet long and as much as 200 feet wide. A second body is a roughly ellipsoidal, dome-shaped mass about 60 feet thick and about 500 by 1,000 feet across. A third ore body may be dome shaped, with a diameter of about 400 feet and a thickness of 40 feet. The ore is mined by open-pit and underground methods and must be beneficiated to produce a marketable product.

\section{WESTERN REGION}

In the western region, magnetite occurrences outnumber those of hematite and limonite, but hematite forms the largest deposits and is the most important iron-ore mineral. The deposits of magnetite and hematite are predominantly replacements of limestone or dolomite. The principal iron-ore deposits in this region are in the Iron Springs district, about 10 miles west of Cedar City, Iron County, southwestern Utah; in the Eagle Mountains, northern Riverside County, southern California; and in the Hartville district, Platte County, southeastern Wyoming. Other iron-ore deposits in this region are relatively small and widely scattered.

\section{IRON SPRINGS DISTRICT, UTAE}

The Iron Springs district covers an area of about 60 square miles. The ore bodies are lens- and wedge-shaped replacements of limestone of Jurassic age encircling 3 oval quartz monzonite intrusions of early Tertiary age which have areas of approximately 5, 10, and 15 square miles. Mixed hematite and magnetite masses are as much as 250 feet thick and extend from a few hundred feet to more than 1,000 feet along the strike and down the dip.

\section{EAGLE MOUNTAINS DEPOSITS, CALIFORNIA}

The Eagle Mountains deposits, the most important of the many and widely distributed iron deposits in California, occur in an area 6 miles long and $11 / 2$ to 2 miles wide. Replacements of metamorphosed limestone or dolomite by magnetite and hematite are closely associated with intrusive quartz monzonite of Precambrian to Tertiary age. Iron ore occurs discontinuously for more than 8,000 feet along the strike of 2 faulted beds which are 80 feet thick and 30 to 300 feet thick and $\operatorname{dip} 20^{\circ}-60^{\circ}$. The major ore bodies are 600 to 1,500 feet long and 70 to 300 feet thick, and they extend 200 to 750 feet down the dip.

\section{HARTVILUE DISTRICT, WYOMING}

The most important iron-ore deposits of the Hartville district, Wy: oming, are irregular lenses of high-grade soft and hard hematite of 
sedimentạry or replacement origin in Precambrian schist. Some of the ore bodies are more than 1,000 feet long and range from a few. feet to about 100 feet in width; one has been reported to have a maximum thickness of 900 feet.

\section{ALASKA}

Iron deposits are known to occur at a number of localities in Alaska (pl. 2), and although discovery of other deposits can be expected, the area appears unfavorable for deposits of major size.

\section{PRINCE OF WAIES ISLAND}

The principal iron deposits of Alaska, which occur in the Kasaan Peninsula of Prince of Wales Island, are replacement masses of magnetite in a folded and faulted part of a sequence of volcanic rocks. Accessory amounts of the copper-bearing mineral, chalcopyrite, are present and locally were sufficiently abundant to have been mined from 1905 to 1918 in the Mount Andrew-Mamie area; minor amounts of gold and silver were also recovered.

The largest iron deposits in the Kasaan Peninsula are in the Mount Andrew-Mamie area, mainly in two gently inclined bodies along the bottom of folds. The ore body at the Mount Andrew mine is a compound mass of numerous contorted layers of magnetite and an approximately equal amount of interlayered rock; it is 600 feet long and 550 feet wide, and extends to a depth of 100 to 150 feet. The deposit at the Mamie mine is at least 400 feet long, 15 to 50 feet thick, and is known to a depth of 400 feet and probably does not extend much deeper.

Deposits in other parts of the Kasaan Peninsula are steeply inclined masses along fracture zones. The main reserve is in the Poor Man deposit, which is 1,500 feet long and 15 to 150 feet wide and is estimated to extend to a depth of at least 200 feet.

Lenses of magnetite in Jumbo basin (pl. 2) are believed to be replacements of marble. The principal lens is 300 feet long and as much as 60 feet thick and extends for more than 400 feet at an inclination of $60^{\circ}$. A few much smaller lenses are present.

\section{HAINES-KLUKWAN}

At Haines-Klukwan, altered volcanic rocks over an area of about 2 square miles average about 13 percent iron recoverable as magnetiteilmenite that is found in disseminated form and in anastomosing masses or veins. The rock in a zone about 2 miles long and 500 feet wide averages about 20 percent iron. An alluvial fan at Klukwan is believed to average about 10 percent magnetic iron over an area of about 4 square miles, with a maximum thickness of about 700 feet. Milling tests by the U.S. Bureau of Mines indicate that concentrates 
containing about 60 percent $\mathrm{Fe}$ and 2 to 4 percent $\mathrm{TiO}_{2}$ can be obtained with a concentration ratio of about $10: 1$.

\section{SNETTISHAM}

Iron deposits at Snettisham are similar to those at Haines and underlie an area approximately 8,000 feet long and 2,000 feet wide. The average crude ore contains about 12 percent magnetic iron, and concentration to 20 percent of the original sample volume is required for assays of 60 percent iron.

\section{PUERTO RICO}

\section{MAYAGÜEZ MESA}

The largest iron-ore resources of Puerto Rico are of lateritic material and are at Mayagüez Mesa in the western part of the island (pl. 2). The limonitic residue underlies an area about 3 miles long by half a mile wide and ranges from 15 to 30 feet in thickness. The value of this material is limited because the amounts of alumina, nickel, and chromium in the ore would probably cause problems in smelting. Also, recent building in the western end of the area would probably preclude mining of a large section of the ore.

\section{JuNCos}

The ore body at $J$ uncos is of the replacement type and is typical of the few small iron deposits in the central and eastern parts of the island. The masses, consisting of magnetite and hematite, are 200 to 1,800 feet long and 12 to 80 feet wide.

\section{MINING AND BENEFICIATION RELATION OF MINING TO GEOLOGY}

The methods by which iron ore is mined are determined by the location, size, shape, and character of the ore body, and by the nature of the enclosing rock. Open-pit operations are used wherever possible for mining mineral deposits having considerable horizontal extent. A few of the many examples of this type of mining made possible by favorable geologic conditions are in the Mesabi district of Minnesota, the Russellville district in Alabama, the deposits at Benson mines and Lake Sanford in the Adirondack district of New York, the Iron Springs district in Utah, and the Eagle Mountains deposits in California.

Underground methods are used to mine deposits where excessive waste rock would have to be removed to obtain the ore by open-pit operations. These deposits generally are steeply inclined or vertical, except in the Birmingham district of Alabama and the Mesabi district of Minnesota. They extend to depths of from 100 feet to more than 3,000 feet and may or may not be exposed at the surface. The deposits 
range in form from generally tabular to roughly cylindrical, and methods of mining must be adapted accordingly. Underground mining is necessary in most of the iron-ore mines in the northeastern region, in the Birmingham district, in the Lake Superior region except for most of the Mesabi and Cuyuna districts, in Missouri, and in Wyoming.

\section{TYPES OF COMMERCLAL ORE}

For commercial purposes, iron ore is classified according to chemical composition and physical character. If impurities are not in excessive amounts, the iron content of the ore is of foremost importance. The percentage differs, however, with mineralogic type of material and source as shown in table 2. If the material as mined meets market specifications for composition, it is classed as direct-shipping ore - that is, it requires no treatment before smelting. The suitability of iron ore for various steel-making processes is limited by its phosphorus content. Ore that has a content of less than 0.045 percent phosphorus to 50 percent iron is classed as bessemer ore, and after smelting can be rapidly made into steel by bessemer converters. Nonbessemer ore may contain as much as 0.18 percent phosphorus, and highphosphorus ore has more than 0.18 percent; steel from these two types of ores is made in open-hearth furnaces.

The physical character of iron ore is the basis of a twofold classification. Lump or hard ore is very compact and coherent material; soft ore is porous, granular, and earthy to only moderately coherent. Lump ore is especially desirable for use in open-hearth furnaces. Each type of material is produced exclusively or predominantly by some mines, but more commonly the types occur together and are not mined separately.

\section{METHODS AND PRODUCTS OF BENEFICIATION}

Iron-bearing material that does not qualify as direct-shipping ore may be beneficiated to make a marketable product. Beneficiation, which is becoming increasingly important, is accomplished by several processes depending upon the type of ore.

\section{ChaNGE IN Chemical Compositron}

Beneficiation related to chemical composition is accomplished by adequate separation of iron-bearing and iron-free constituents present in the untreated material (crude ore) so that the percentages of iron and other elements in the product meet specifications.

Crude ore may be heated in kilns to drive off excessive moisture or to remove carbon dioxide from sideritic ore and produce much higher grade iron oxides.

More common processes of beneficiation depend upon differences in specific gravity to separate heavy ore minerals from lighter value- 
less gangue minerals. Concentration by relative buoyancy is achieved through the use of water in a variety of washing arrangements or the use of circulating heavy media. Centrifugal force produces concentration in Humphrey spirals and cyclone separators.

Flotation is a method of beneficiation in which certain minerals are caused to adhere to bubbles and float at the surface of a liquid while other minerals remain submerged, thus effecting a separation between ore and waste material.

Magnetic separation is commonly used to upgrade crude magnetitebearing ore.

\section{Change in physical condition}

Fine-grained ores and concentrates are subject to excessive losses in shipment and are not suitable for direct use in common smelting operations, but these fine-grained materials can be converted into marketable products by agglomeration to sinter, nodules, pellets, or briquets. Sintering forms porous, somewhat clinkerlike masses by combustion in a layer of ore mixed with fine particles of coal or coke. Nodulizing produces spherical masses about 4 to 5 inches in diameter by the heating of a mixture of fine-grained ore or concentrate and suitable binding material in an inclined rotary kiln. Pelletizing produces spherical masses about one-half inch in diameter by mixing finegrained concentrates with binding material and, sometimes, solid fuel, and passing the mixture through balling drums to form pellets that are partially sintered in a shaft furnace or on a moving hearth.

\section{TACONITE BENEFICIATION}

Developments in the utilization of magnetic taconite in the eastern part of the Mesabi district are especially significant because of their magnitude. Magnetic separation and subsequent pelletizing have been sufficiently successful that one plant, with an annual capacity of nearly 4 million tons of concentrates, was put into operation in March 1956 , and another plant, with an annual capacity of 7.5 million tons of concentrates, was completed in late 1957. The magnetic taconite contains about 22 percent iron in the form of magnetite, but concentration of 3 tons of crude ore into 1 ton of pellets increases the iron content to 64 percent. The greater costs of beneficiating magnetic taconite as compared to production of direct-shipping ore is mainly or entirely offset by savings in shipping charges and in operation of blast furnaces. It has been estimated (Gruner, 1954) that 6,000 million tons of magnetic taconite is available for open-pit mining and is amenable to present methods of beneficiation; the amount of resulting concentrates should be about 2,000 million tons, which would equal the total production of the Mesabi district from the beginning of production in 1892 
through 1955. The success of taconite beneficiation assures that the Lake Superior region will probably continue to be the most important source of iron ore, and that it may have an even more predominant position in the future; the importance of this development may be comparable to the original discovery of the Mesabi district.

\section{IRON-ORE RESERVES AND POTENTIAL ORE}

\section{CLASSIFICATION AND TERMINOLOGY}

The terms "reserves," "potential ore," and "resources" as used in this report follow the concepts of Blondel and Lasky (1955, p. 173):

... we suggest classifying mineral masses into at least two broad categories: (1) those considered exploitable for usable material under existing economic and local conditions-reserves; and (2) those, which to be exploited for usable material, demand more favourable conditions than the existing ones-potential ores. ... The term "resources" would, in that case, be used to designate the total of reserves plus potential ores.

Potential ore thus includes (a) material of lower iron content than that which is now being mined, (b) material of usable grade in deposits of less than minable size, (c) deposits of minable size which contain excessive quantities of impurities, and (d) deposits technologically satisfactory but too remote from transportation and blast furnaces for present use. Nevertheless, some deposits that have unfavorable features may be mined under emergency conditions.

\section{FACTORS IN RESOURCE APPRAISAI}

Estimates of iron-ore reserves and potential ore in a deposit or group of deposits include evaluation of many uncertain and variable factors related to the grade, dimensions, and geologic occurrence of the ore bodies. Data obtained from test pits, trenches, exploratory shafts, and drilling are the basis for most estimates of the grade of ore and the dimensions of an ore body, but these exploratory operations may provide sufficient information on only part of the total deposit that may be ultimately suitable for development. Concepts concerning the occurrence and origin of the deposit will then in turn have an important influence on interpolation and extrapolation relative to estimating the tonnage and grade of the deposit as a whole. The reliability of reserve estimates is dependent, therefore, upon both the geologic data available and the validity of the interpretations used in computing the tonnage.

The estimated reserves of a mineral commodity are commonly expressed as tonnage and grade, or metal content, but with an implied qualification that mining, milling, smelting, and selling of products from the material probably will yield a satisfactory remuneration. The primary purpose of estimating reserves of a mineral commodity is to determine the value of the deposits and to plan intelligently and 
effectively for their exploitation. Not only must the methods and facilities for mining, milling, and smelting be planned, but the tonnage and grade of the reserve should be sufficiently well established to provide adequate assurance for the amortization of the capital expenditures and for some profit. The estimated reserves are an indication of that assurance, but they are not generally a prediction of the total amount of ore that can be produced from a deposit or district. The uncertainty of this proportional relation between estimated reserves and total available ore may therefore lead to false: predictions and conclusions if based only upon the oversimplified. equation of estimated reserves, divided by annual production. Estimates of reserves as a whole must be considered transitory, because they are continually being affected by discovery of new deposits, development, production, and especially by advances in mineral-industry technology. Furthermore, estimates of iron-ore reserves may increase as the physical and technical problems involved in utilization of potential ore become solved and the material is reclassified as reserves:

Reserves in an inventory sense are composed of material that probably can be profitably exploited within a reasonable period; profitable exploitation is dependent upon the differential between cost and selling price, and a reasonable period is determined by plans of the mining company. Both of these factors are in part influenced by taxation. Thus, in another respect, the estimated reserves are only a part of the total available supply, because the amount that is estimated to be minable at any specified time is determined by existing or expected economic and technologic conditions. It is evident from the foregoing that figures for reserves are only approximate.

\section{TABULATION OF IRON-ORE RESOURCES}

The tabulations of iron-ore resources (tables 3, 4, and 5) are the synthesis of many published and unpublished data, most of which are based on fieldwork by the U.S. Geological Survey. The compilation would not have been possible, however, without the cordial cooperation of the State geologists and other officials of the States involved, the U.S. Bureau of Mines, and many individuals who furnished information not otherwise available.

The total domestic iron-ore resources in continental United States are estimated to be approximately 75,000 million long tons of crude ore. Table 3 summarizes the detailed data and shows that iron-ore reserves (direct-shipping ore and concentrates by present methods) are estimated to be about 5,500 million long tons (obtained from about 10,000 million tons of reserves of crude ore), and potential ores are estimated to be about 65,000 million long tons. The potential ore 
may yield 25,000 million long tons of concentrates and some directshipping ore. Alaska has approximately 5 million tons of iron-ore reserves; Puerto Rico has small reserves. Both Alaska and Puerto Rico are estimated to have large amounts of potential ore. Table 4 lists individual iron-ore areas and deposits that are estimated to contain at least 200,000 long tons each of reserves or potential ore, arranged by regions of continental United States and alphabetically by States within the regions. Data on iron deposits of Alaska and Puerto Rico are given in table 5. The estimates are in terms of crude ore except as otherwise indicated. Most published figures for reserves that are shown in the tables have not been corrected for depletion due to subsequent mining, because continuing exploration may increase the known reserves at a rate equal to or exceeding that of extraction. Table 6 is a finding list for iron deposits shown on pl. 2 and in tables 4 and 5 .

For some areas and deposits listed in the tables and shown on the map (pl. 2), only unpublished estimates of reserves and potential resources are available and no references can be given; for others, data are only general estimates from published reports. The magnitude of such estimates is indicated by the designations "small" (less than 2 million long tons), "moderate" ( 2 million to 10 million long tons), and "large" (more than 10 million long tons).

Those States that have no known iron deposits of 200,000 long tons or more have been omitted from the tabulation. However, references to publications on some deposits that may be of importance in the future, including deposits in States not included in the tabulation, are cited in the geographic index to the selected bibliography (p. 127) under the specific region in which the State is included.

The estimates in the resource tabulations (tables 3, 4, and 5) are classed as measured, indicated, and inferred, according to Geological Survey and Bureau of Mines usage:

Measured ore designates tonnage for which size, shape, and mineral content are well established.

Indicated ore is used for tonnage computed partly from specific measurements and partly from projection for a reasonable distance on geologic evidence.

Inferred ore is tonnage for which quantitative estimates are based upon broad knowledge of the geologic character and relations of the deposit and for which there are few, if any, samples or measurements.

The iron-ore resources that are believed to be the most important in the United States are marked by an asterisk $\left({ }^{*}\right)$. The areas or deposits are numbered by States as on plate 2.

All grades are given in terms of natural (undried) material, un- 
less otherwise stated. In some instances the grades have been revised to agree with more recent information than that given in the references cited.

TABLE 3.-Summary of iron-ore resources of the United States, Alaska, and Puerto Rico

\begin{tabular}{|c|c|c|c|c|c|c|c|}
\hline \multirow{3}{*}{$\begin{array}{c}\text { Region and type of reserves or } \\
\text { potential ore }\end{array}$} & \multicolumn{5}{|c|}{ Reserves } & \multicolumn{2}{|c|}{ Potential ore } \\
\hline & \multicolumn{2}{|c|}{$\begin{array}{l}\text { Iron content (per- } \\
\text { cent) }\end{array}$} & \multicolumn{3}{|c|}{$\begin{array}{l}\text { Estimated tonnage (millions } \\
\text { of long tons) of direct-ship- } \\
\text { ping ore and concentrates }\end{array}$} & \multirow{2}{*}{$\begin{array}{l}\text { Approxi- } \\
\text { mate } \\
\text { iron } \\
\text { content } \\
\text { (percent) }\end{array}$} & \multirow{2}{*}{$\begin{array}{c}\text { Estl- } \\
\text { mated } \\
\text { tonnage } \\
\text { (millions } \\
\text { of long } \\
\text { tons) }\end{array}$} \\
\hline & $\underset{\text { (approx.) }}{\text { Range }}$ & $\begin{array}{c}\text { Shipping } \\
\text { grade } \\
\text { (approx.) }\end{array}$ & $\begin{array}{c}\text { Meas- } \\
\text { ured and } \\
\text { indi- } \\
\text { cated }\end{array}$ & Inferred & Total & & \\
\hline
\end{tabular}

\section{UNITED STATES, BY REGIONS}

\begin{tabular}{|c|c|c|c|c|c|c|c|}
\hline $\begin{array}{l}\text { Northeastern: } \\
\text { Concentrates. } \\
\text { Crude ore } \\
\text { Do. }\end{array}$ & $25-45$ & 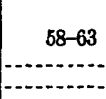 & 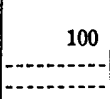 & 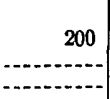 & 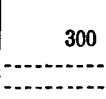 & $\begin{array}{r}43 \\
\quad 27\end{array}$ & $\begin{array}{r}1,230 \\
1,620\end{array}$ \\
\hline Total. & & & 100 & 200 & 300 & & 2,850 \\
\hline $\begin{array}{l}\text { Southeastern: } \\
\text { Direct-shipping ore. } \\
\text { Concentrates.. } \\
\text { Crude ore } \\
\text { Do } \\
\text { Do }\end{array}$ & 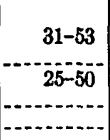 & $\begin{array}{l}36 \\
50 \\
-2-\end{array}$ & 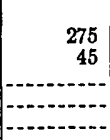 & $\begin{array}{r}275 \\
15 \\
2 \\
2 \\
-\end{array}$ & 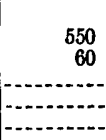 & $\begin{array}{r}50 \\
37 \\
31\end{array}$ & $\begin{array}{r}110 \\
1610 \\
10,500\end{array}$ \\
\hline Total $\ldots$ & 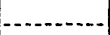 & $-\cdots$ & 320 & 290 & 610 & $\ldots$ & 111,220 \\
\hline $\begin{array}{l}\text { Lake Superior: } \\
\text { Direct-shipping and inter- } \\
\text { mediate crude ore } \\
\text { Magnetic concentrates } \\
\text { Crude ore } \\
\text { Do... }\end{array}$ & 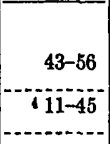 & $\begin{array}{l}60 \\
63 \\
-2\end{array}$ & $\begin{array}{r}1,450 \\
800 \\
\hdashline \\
\hdashline\end{array}$ & $\begin{array}{r}550 \\
1,200 \\
\hdashline\end{array}$ & $\begin{array}{r}2,000 \\
2,000 \\
\hdashline\end{array}$ & $\begin{array}{r}25-45 \\
+22\end{array}$ & $\begin{array}{l}35,000 \\
15,000\end{array}$ \\
\hline Total & - & $\ldots$ & 2,250 & 1,750 & 4,000 & $\cdots$ & 50,000 \\
\hline $\begin{array}{l}\text { Central and gulf: } \\
\text { Concentrates. } \\
\text { Crude ore } \\
\text { Do. }\end{array}$ & $40-50$ & $-\cdots$ & 825 & 825 & 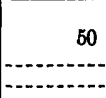 & $\begin{array}{l}50 \\
40\end{array}$ & $\begin{array}{r}3 \\
1113\end{array}$ \\
\hline ,Total. . . & - & $-\ldots$ & 825 & 525 & 50 & $\cdots$ & 1116 \\
\hline 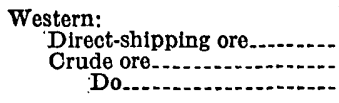 & $\begin{array}{c}30-55 \\
-35\end{array}$ & $\ldots$ & $\begin{array}{r}180 \\
\hdashline\end{array}$ & $\begin{array}{r}310 \\
\end{array}$ & $\begin{array}{r}480 \\
\end{array}$ & $\begin{array}{l}50 \\
40\end{array}$ & $\begin{array}{r}1210 \\
1290\end{array}$ \\
\hline Total $\ldots$ & -.......... & $\ldots$ & 180 & 310 & 490 & $\ldots$ & 1500 \\
\hline Grand total. & $\ldots$ & $\ldots$ & 2,875 & 2,575 & 65,450 & $-\cdots$ & 1764,686 \\
\hline
\end{tabular}

ALASKA

\begin{tabular}{l|r|r|r|r|r|r|}
\hline Crude ore.................... & $45-52$ & $\ldots$ & 5 & $10-50$ & Large \\
\hline
\end{tabular}

\section{PUERTO RICO}

\begin{tabular}{l|r|r|r|r|r|r|r}
\hline Crude ore.............................. Small & 60 & Small & 40 & Large \\
\hline
\end{tabular}

1 Conservative estimate.

8 From magnetic taconite of the Mesabi range.

8 Taconite of the Mesabi range and similar low-grade Iron-formation of other ranges.

1 Magnetic taconite of the Mesabi range contains 11 to 34 percent iron that is recoverable magnetically; the average is 22 percent.

s Mostly a preliminary estimate of Texas ore by Perkins and Lonsdale (1955).

- Obtained from about 10,000 million long tons of reserves of crude ore.

1 Equivalent to about 25,000 million long tons of concentrates plus a little direct-shipping ore. 


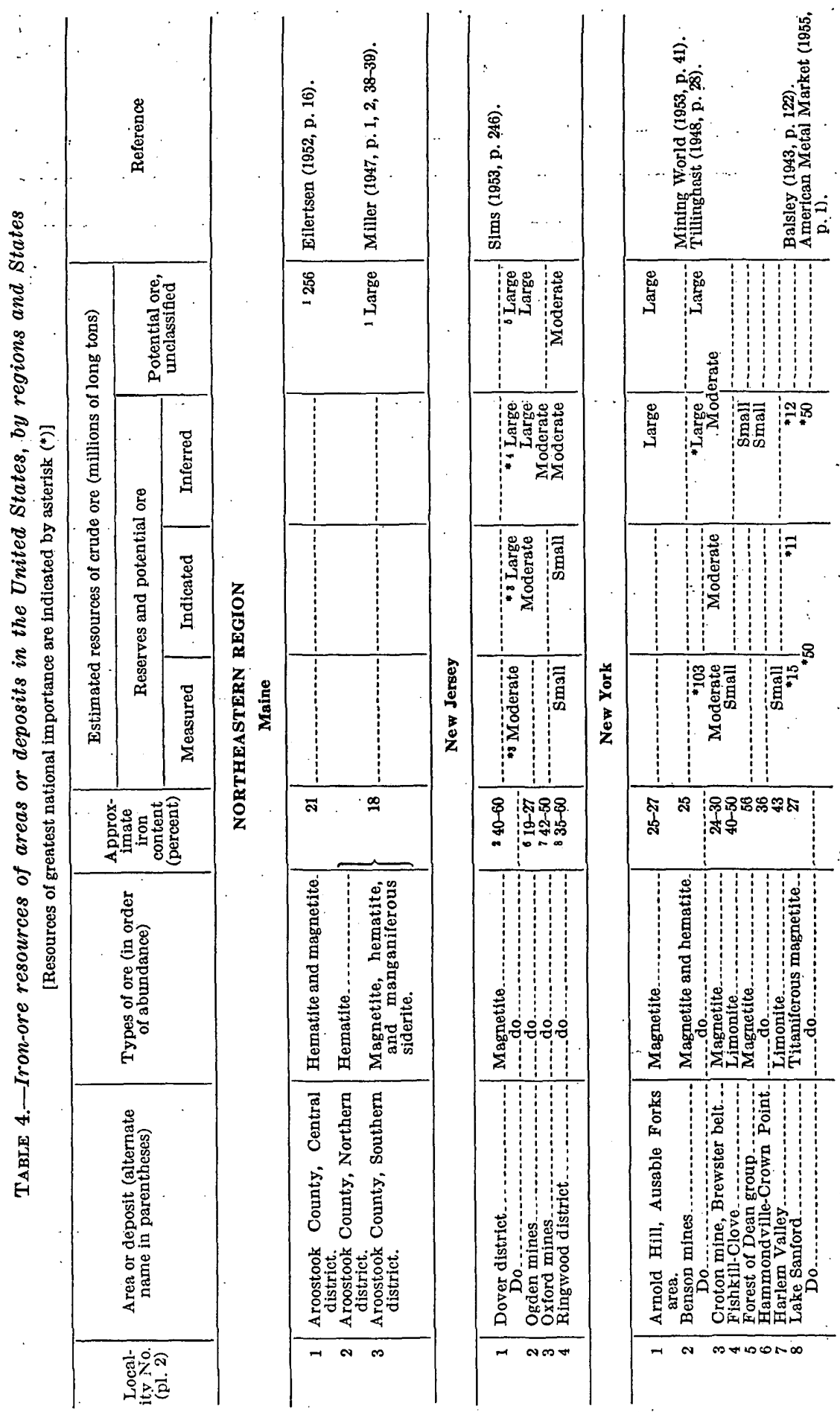


IRON-ORE RESOURCES OF THE UNITED STATES, 1955

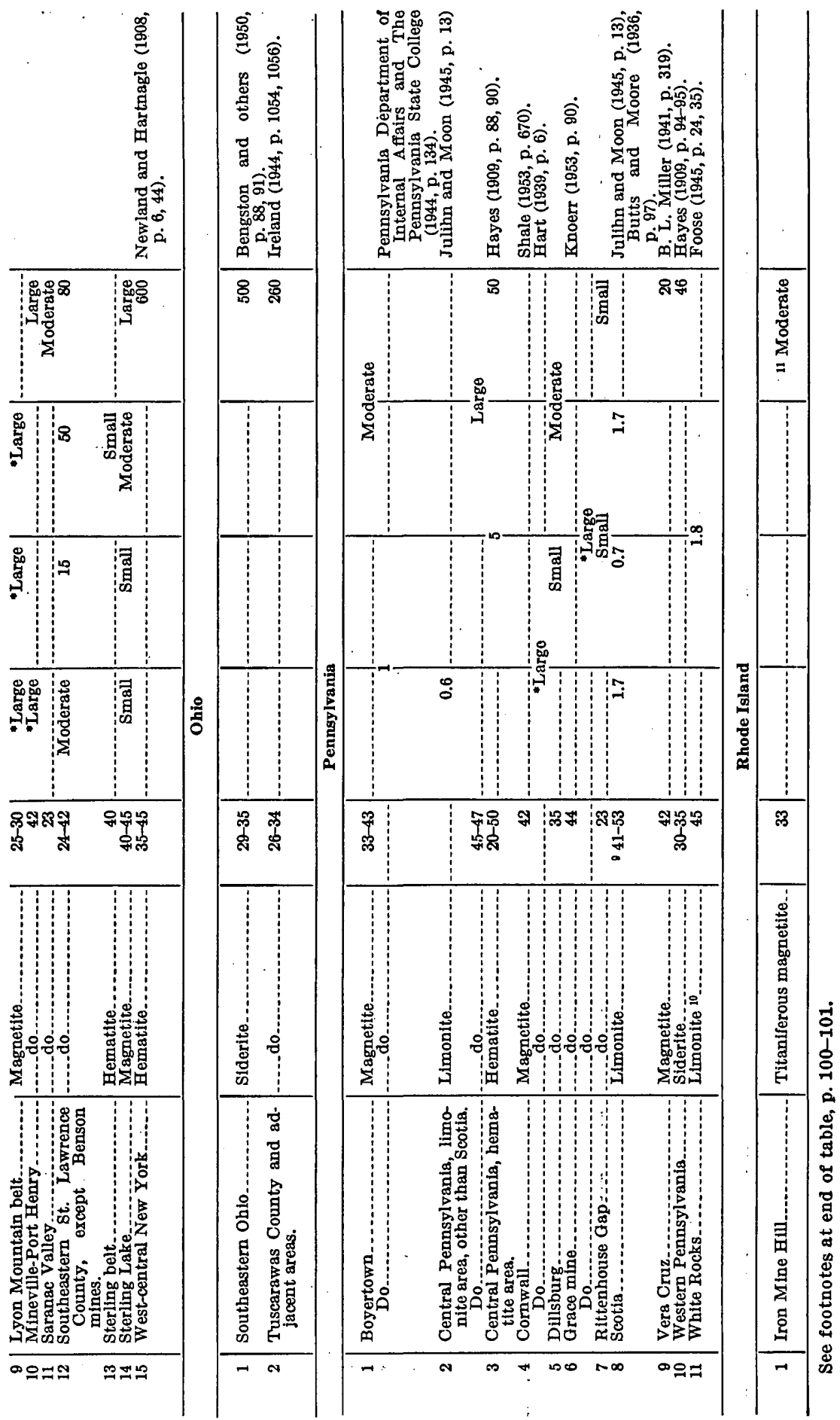




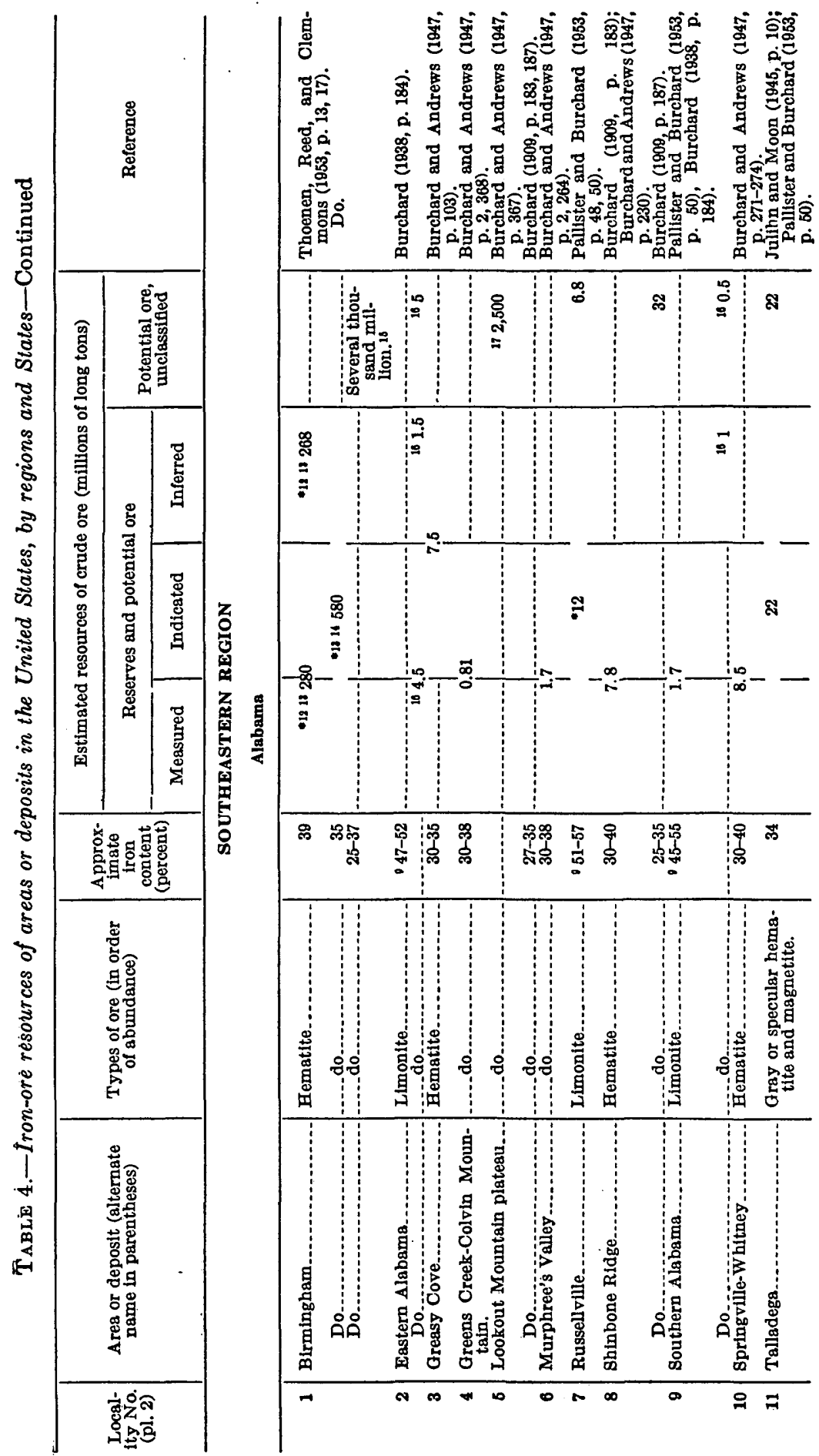


IRON-ORE RESOURCES OF THE UNITED STATES, 1955
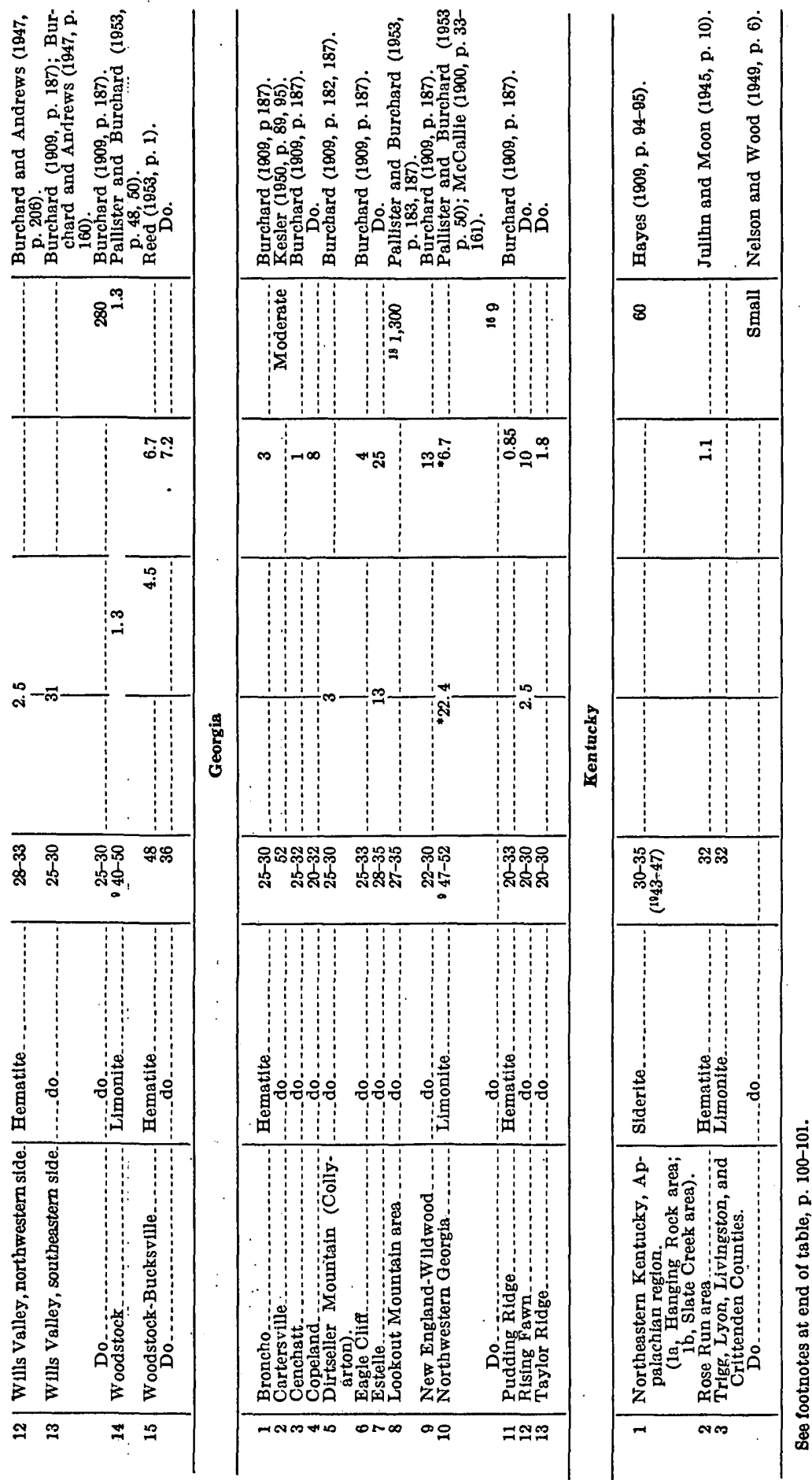

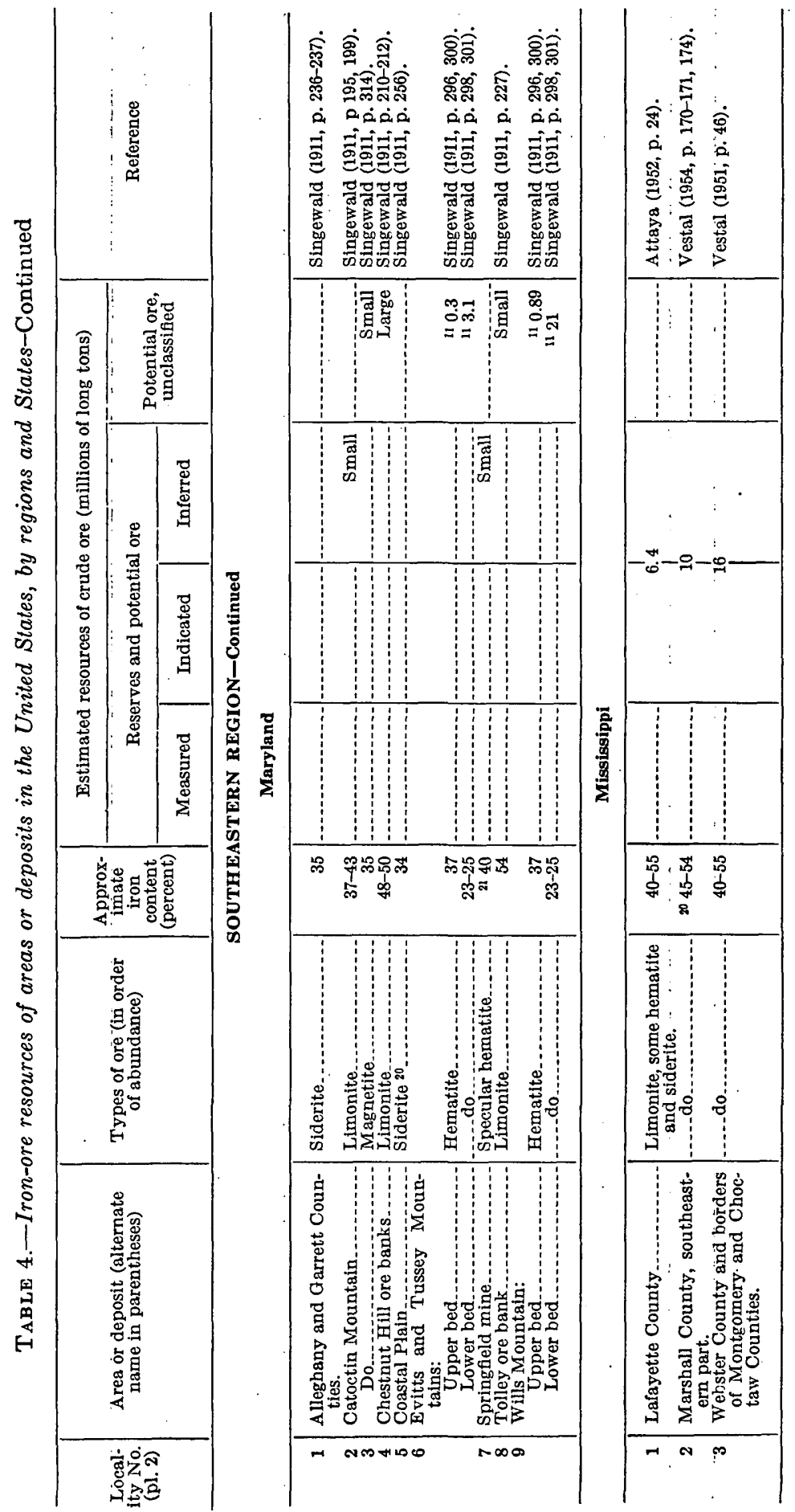


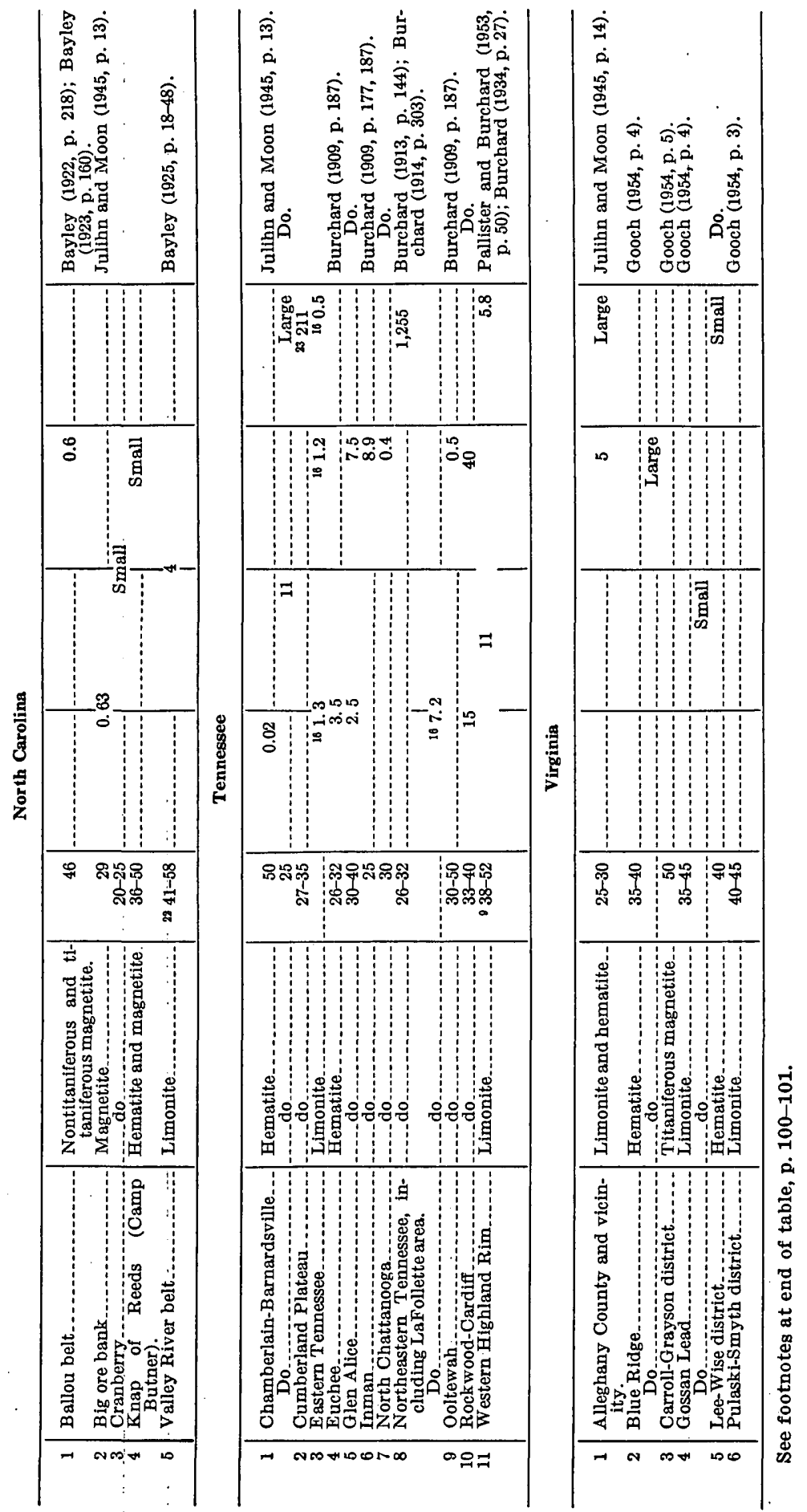




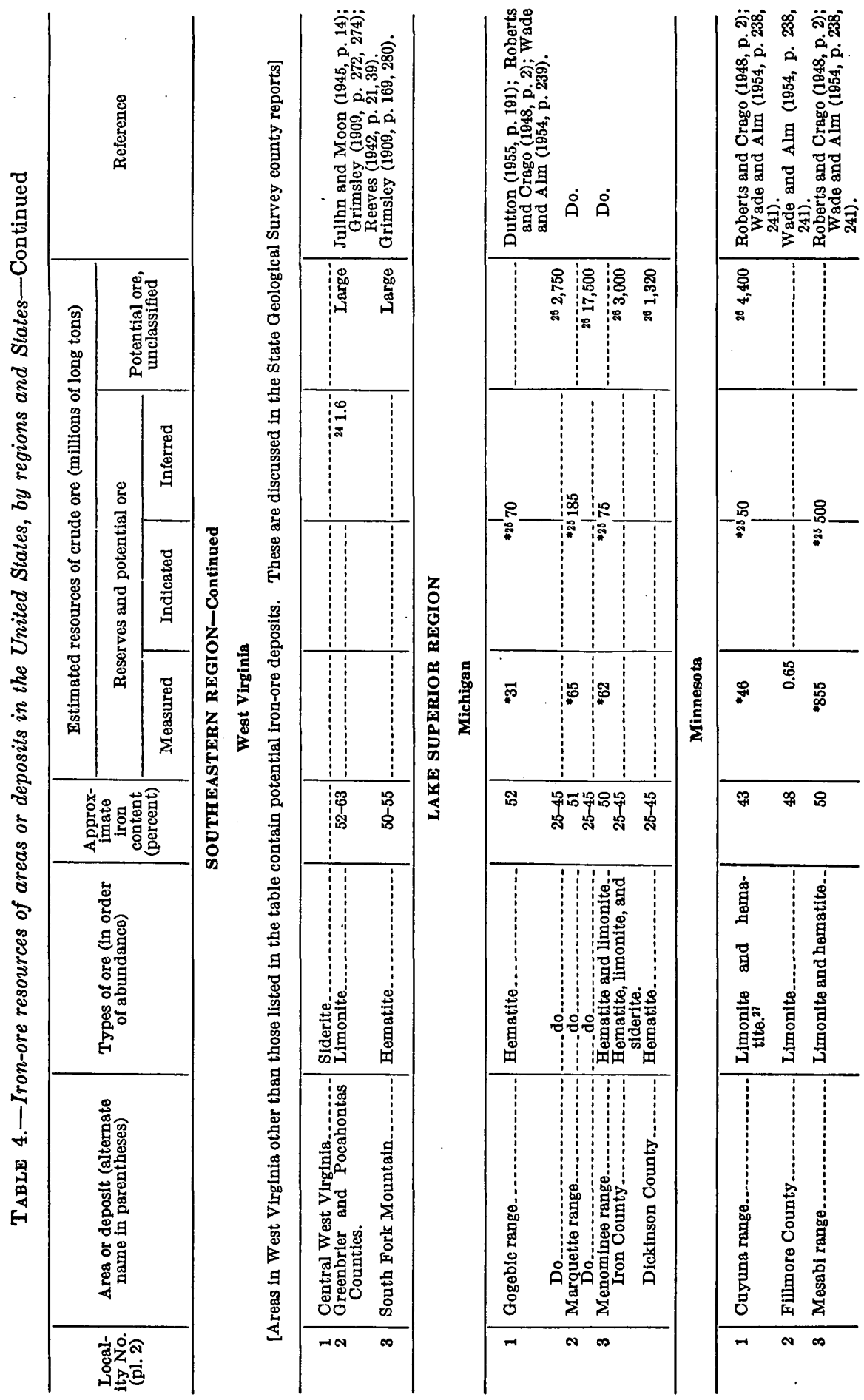




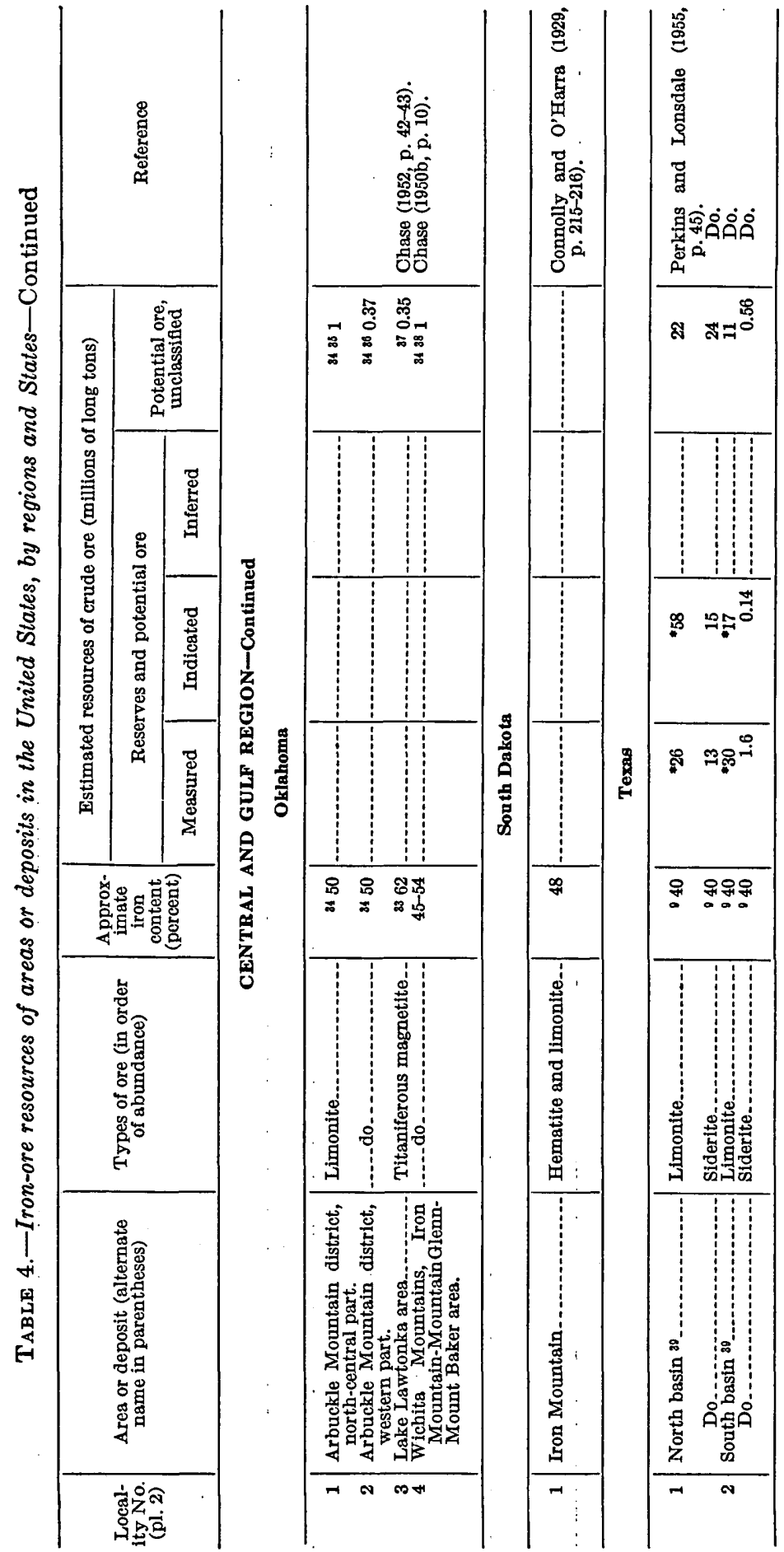


IRON-ORE RESOURCES OF THE UNITED STATES, $1955 \quad 97$

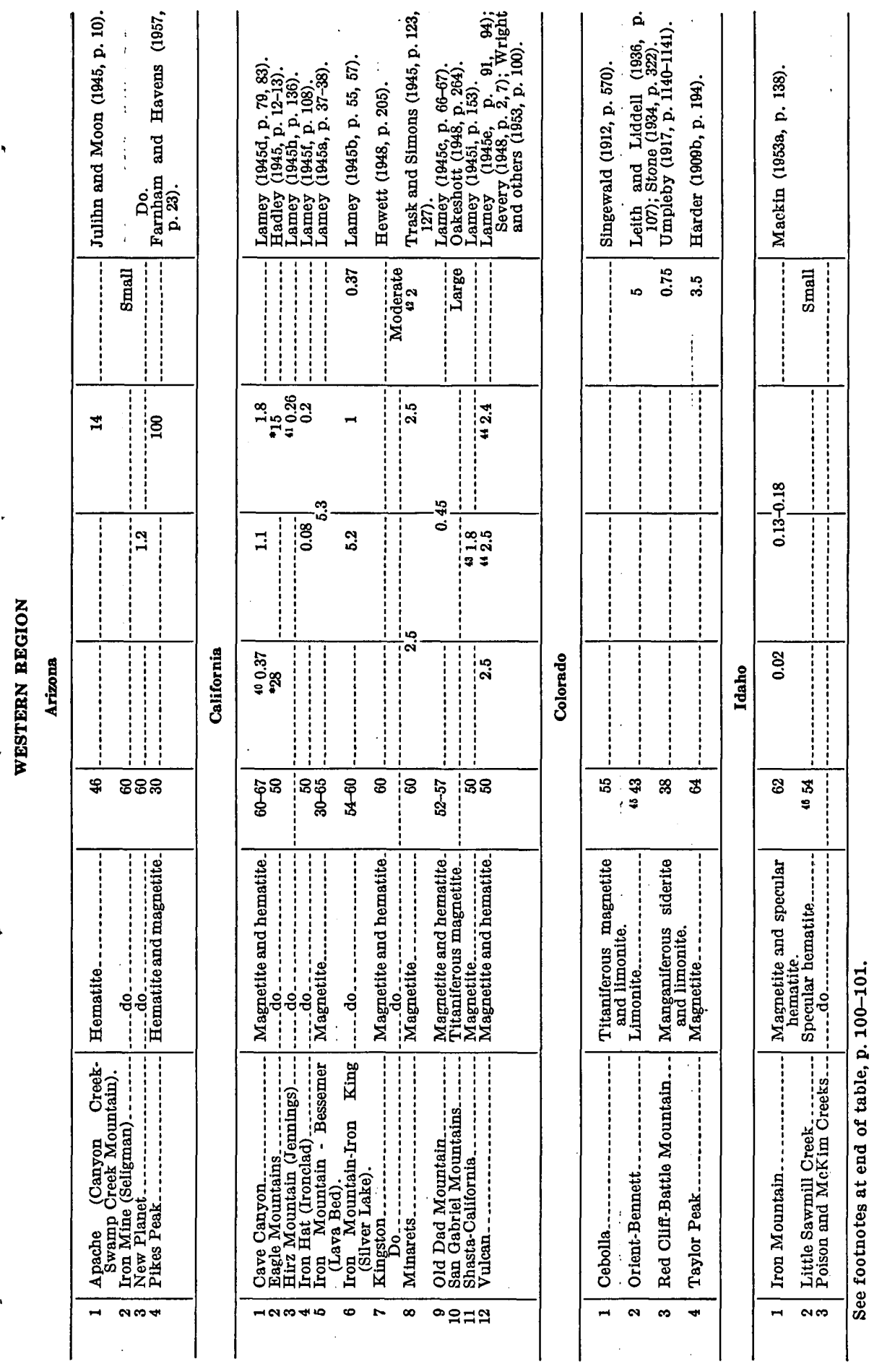




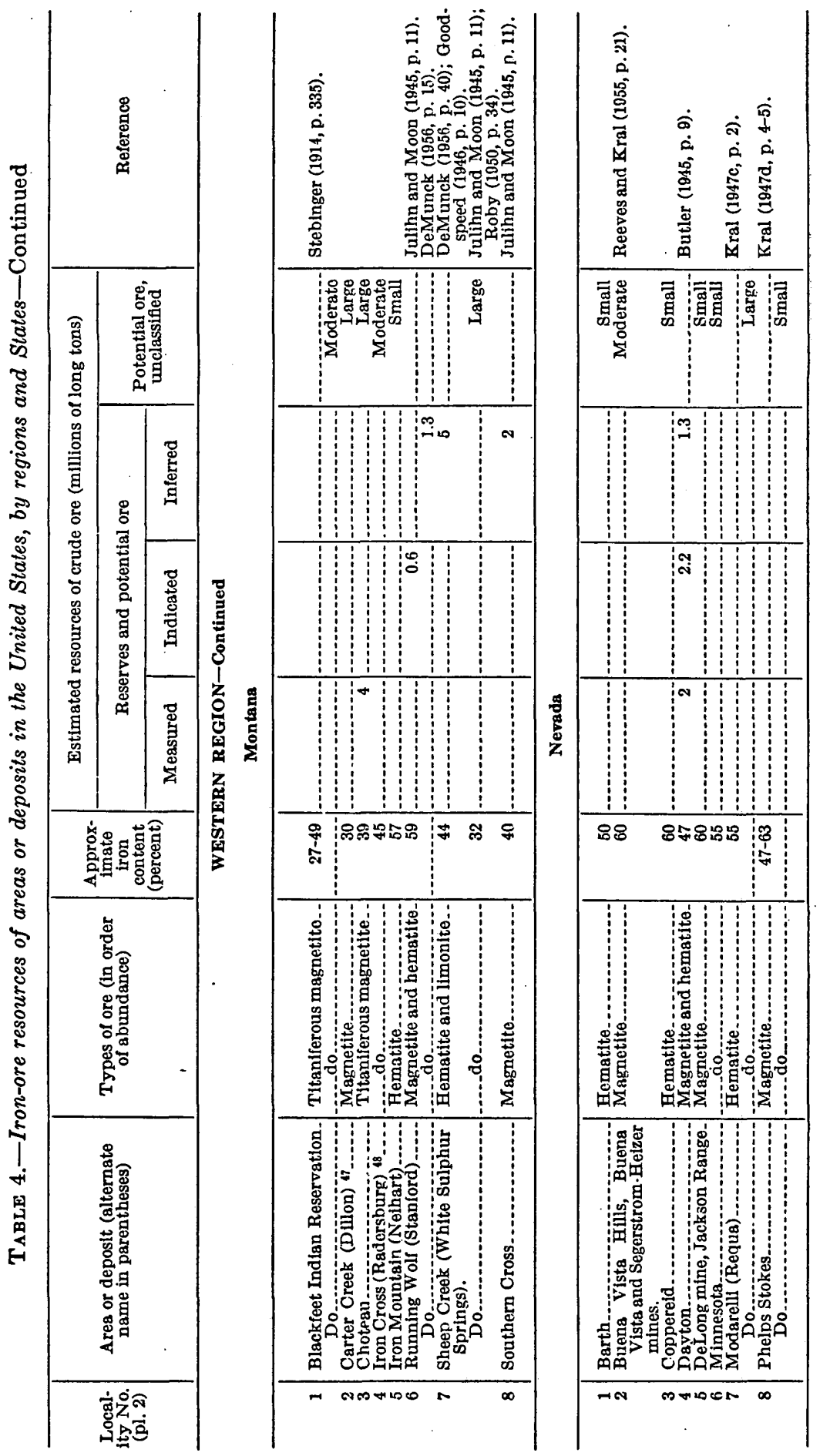


IRON-ORE RESOURCES OF THE UNITED STATES, 1955

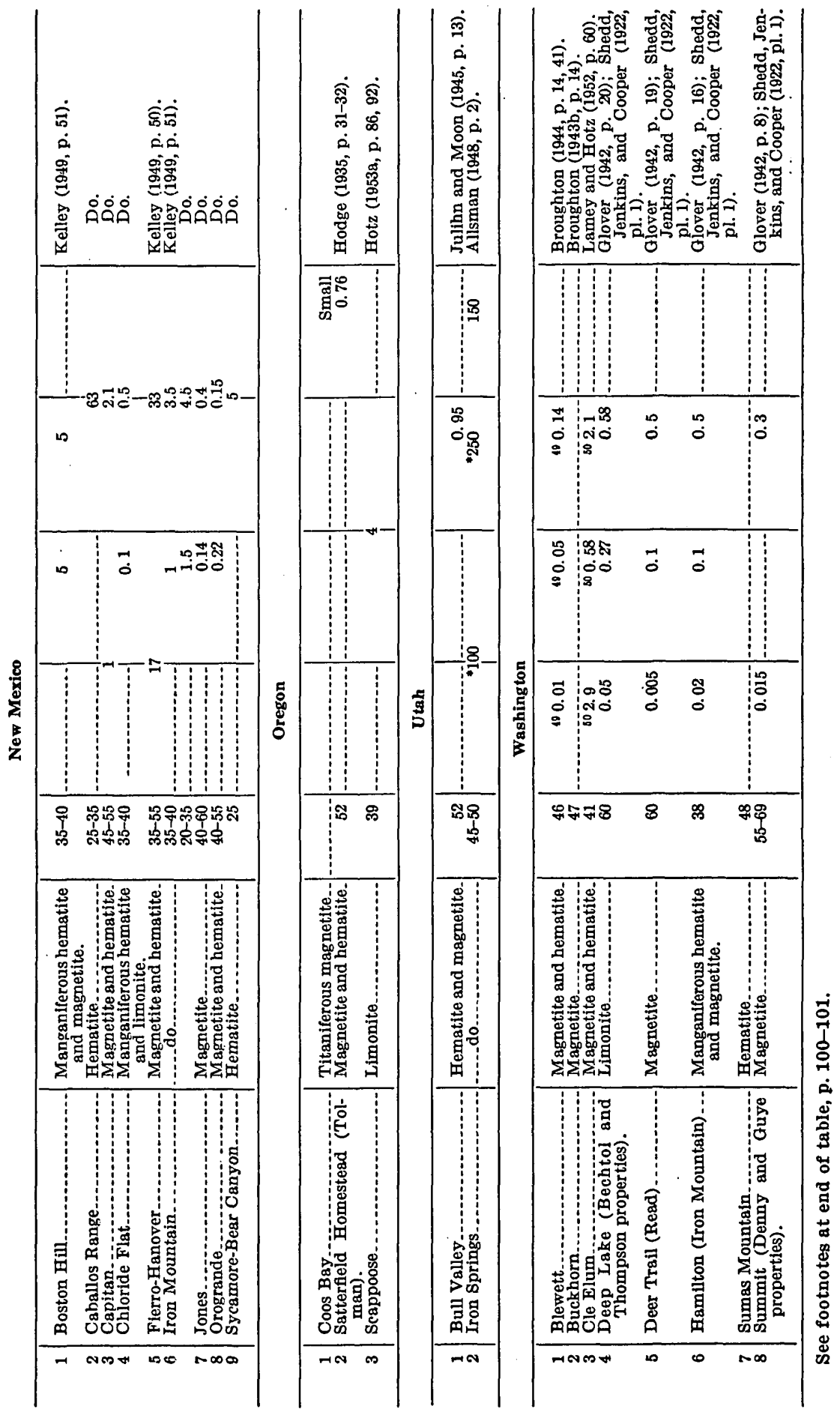




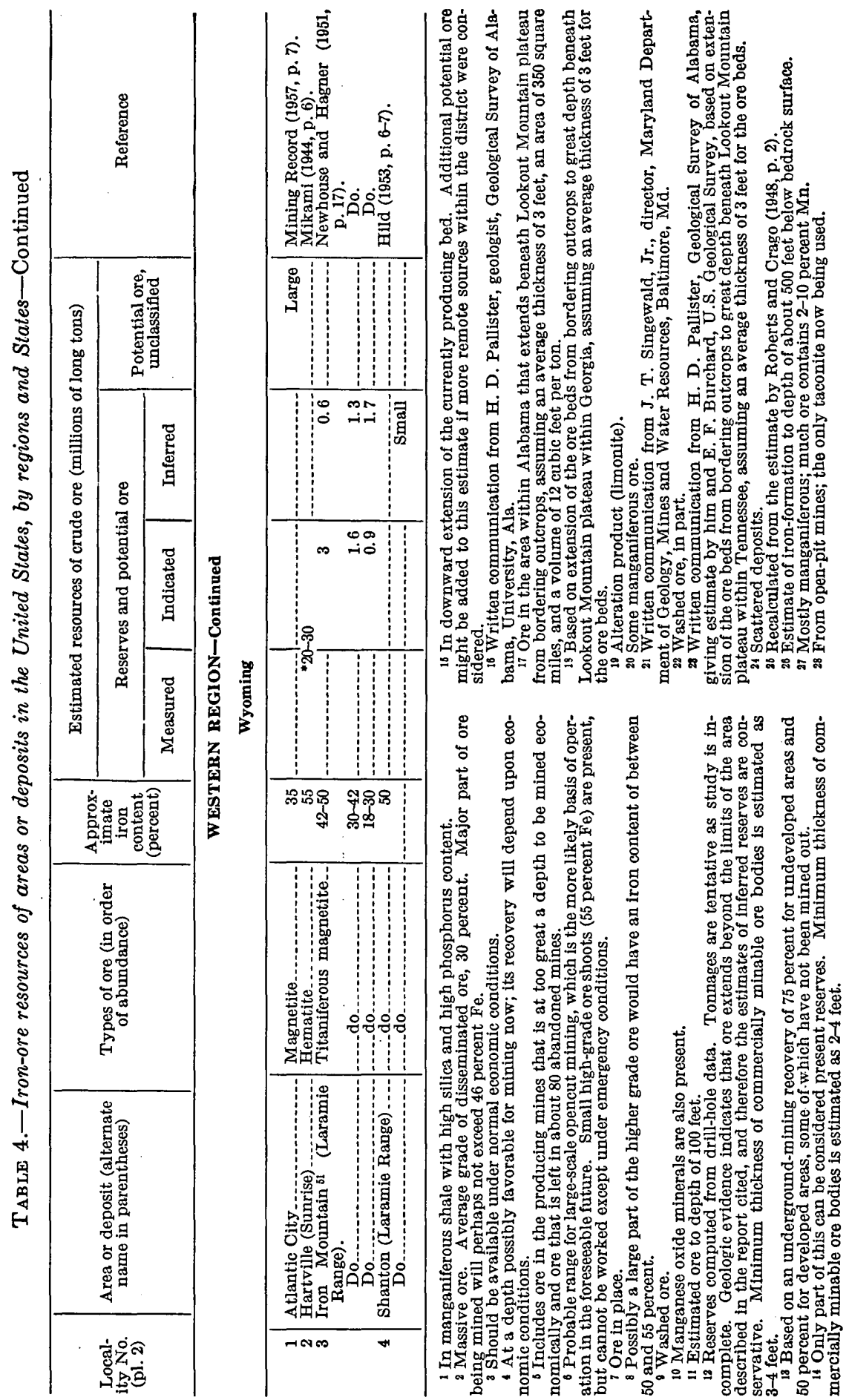


IRON-ORE RESOURCES OF THE UNITED STATES, 1955101
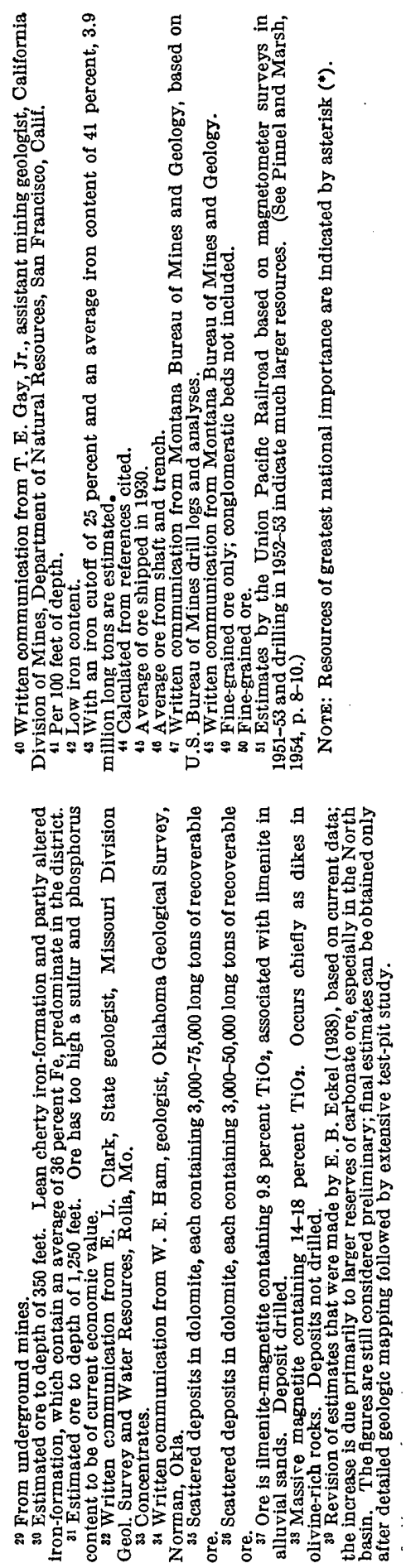


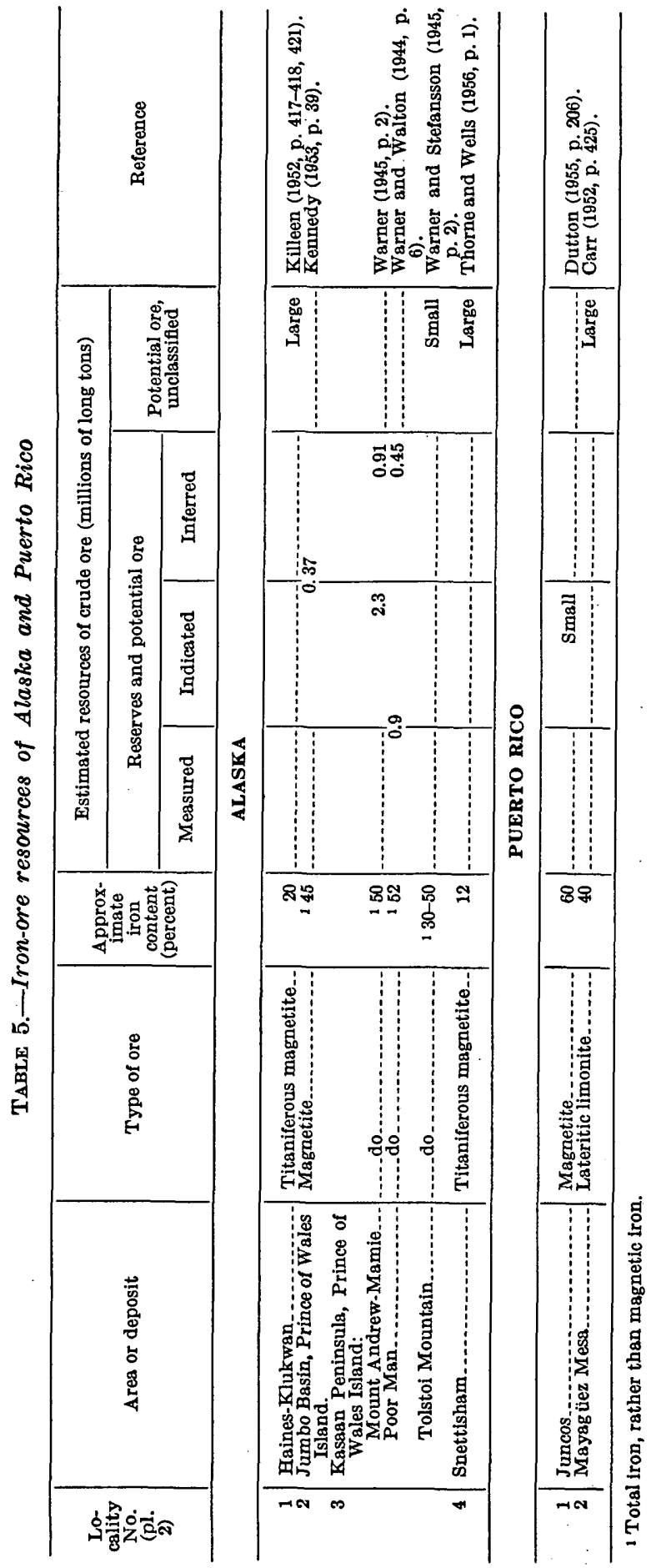


TABLE 6.-Alphabetical list of iron deposits in the United States, including Alaska and Puerto Rico.

[8ymbols for regions: CG, central and gulf; LS, Lake Superior; NE, northeastern; 8E, southeastern; and W, western]

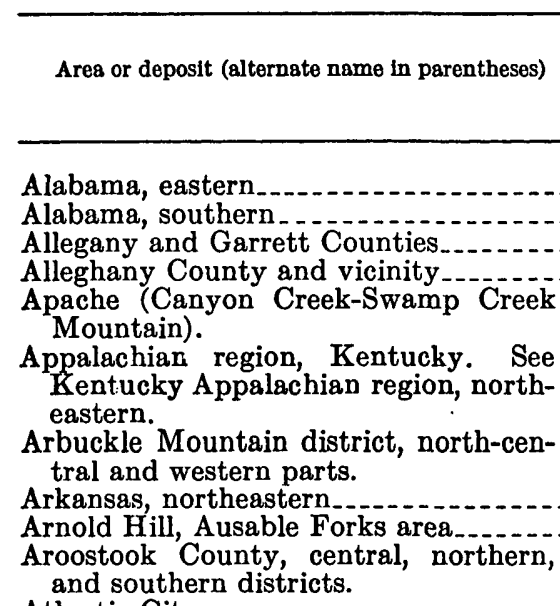

Ausable Forks area, New York. See Arnold Hill.

Ballou belt

Baraboo range

Barnardsville, Tennessee. See Chamberlain-Barnardsville.

Barth Cliff-Battle Mountain.

Bear Canyon, New Mexico. See Sycamore-Bear Canyon.

Bechtol, Washington. See Deep Lake.

Bennett, Colorado. See Orient-Bennett.

Benson mines

Bessemer, California. See Iron Mountain-Bessemer.

Big ore bank

Birmingham.

Blackfeet Indian Reservation.....

Black River Falls. .

Blewett. . .

Blue Ridge

Boston Hill

Bourbon-Sullivan.

Boyertown

Brewster belt, New York. See Croton mine.

Broncho

Buckhorn - Ālabama. See WoodstockBucksville.

Buena Vista Hills (Buena Vista and Segerstrom-Heizer).

Bull Valley

Caballos Range

\begin{tabular}{|c|c|c|}
\hline Region & State or Territory & $\begin{array}{l}\text { Number on } \\
\text { pl. } 2 \text { and } \\
\text { in tables } \\
4 \text { and } 5\end{array}$ \\
\hline SE & Alabama ... & 2 \\
\hline SE & Marvland & 9 \\
\hline $\mathrm{SE}$ & Virginia & 1 \\
\hline $\mathrm{W}_{-}$ & Arizona & 1 \\
\hline CG. & Oklahoma_... & 1,2 \\
\hline CG & Arkansas & 2 \\
\hline $\mathrm{NE}$ & New York & 1 \\
\hline & Maine ..... & $1,2,3$ \\
\hline W. & Wyoming --- & 1 \\
\hline $\mathrm{SE}$. & North Carolina & 1 \\
\hline LS. & Wisconsin & 1 \\
\hline $\mathrm{W}_{-}$ & Nevada $\ldots . .$. & 1 \\
\hline ' & & \\
\hline NE. & New York. & 2 \\
\hline SE. & North Carolina... & 2 \\
\hline & Alabama & 1 \\
\hline $\mathrm{LS}_{-}$ & $\begin{array}{l}\text { Montana } \\
\text { Wisconsin }\end{array}$ & $\begin{array}{l}1 \\
2\end{array}$ \\
\hline $\mathrm{W}_{-}$ & Washington & 1 \\
\hline $\mathrm{SE}$ & Virginia. & 2 \\
\hline$W_{-1} \ldots$ & New Mexico...... & 1 \\
\hline $\mathrm{CG}_{\mathrm{NE}}-\mathrm{P}^{--}$ & $\begin{array}{l}\text { Missouri__. } \\
\text { Pennsylvania }\end{array}$ & 1 \\
\hline & Georgia & 1 \\
\hline W... & Washington. & 2 \\
\hline . & & \\
\hline W & Nevada_. & 2 \\
\hline $\mathrm{W}_{-}$ & Utah & 1 \\
\hline W.. & New Mexico. . . & 2 \\
\hline
\end{tabular}


TABLE 6.-Alphabetical list of iron deposits in the United States, including Alaska and Puerto Rico-Continued

[Symbols for regions: CG, central and gulf; LS, Lake Superior; NE, northeastern; SE, southeastern; and W, western]

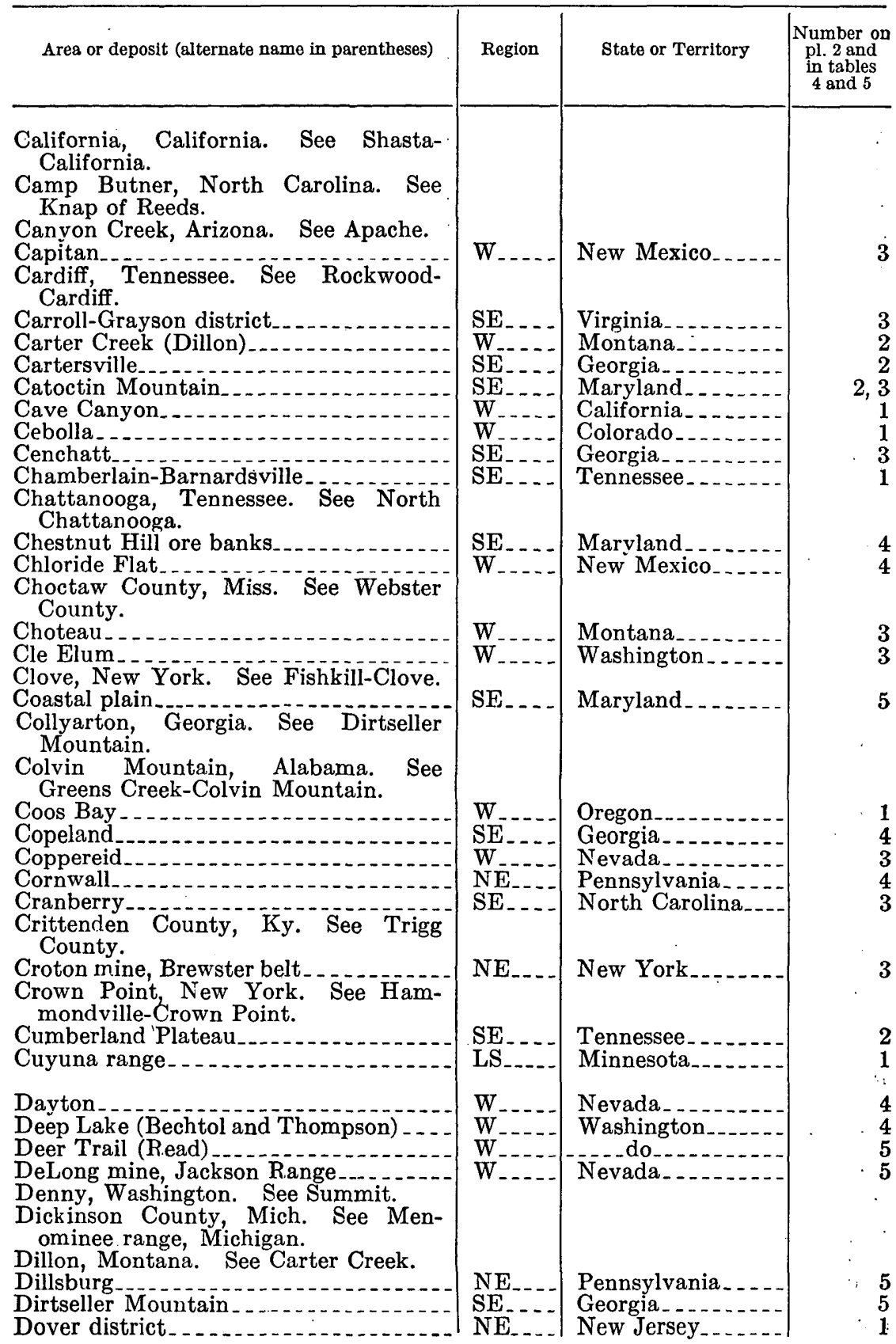


TABLE 6.-Alphabetical list of iron deposits in the United States, including Alaska. and Puerto Rico-Continued

[Symbols for regions: CG, central and gulf; LS, Lake Superior; NE, northeastern; SE, southeastern; and W, western]

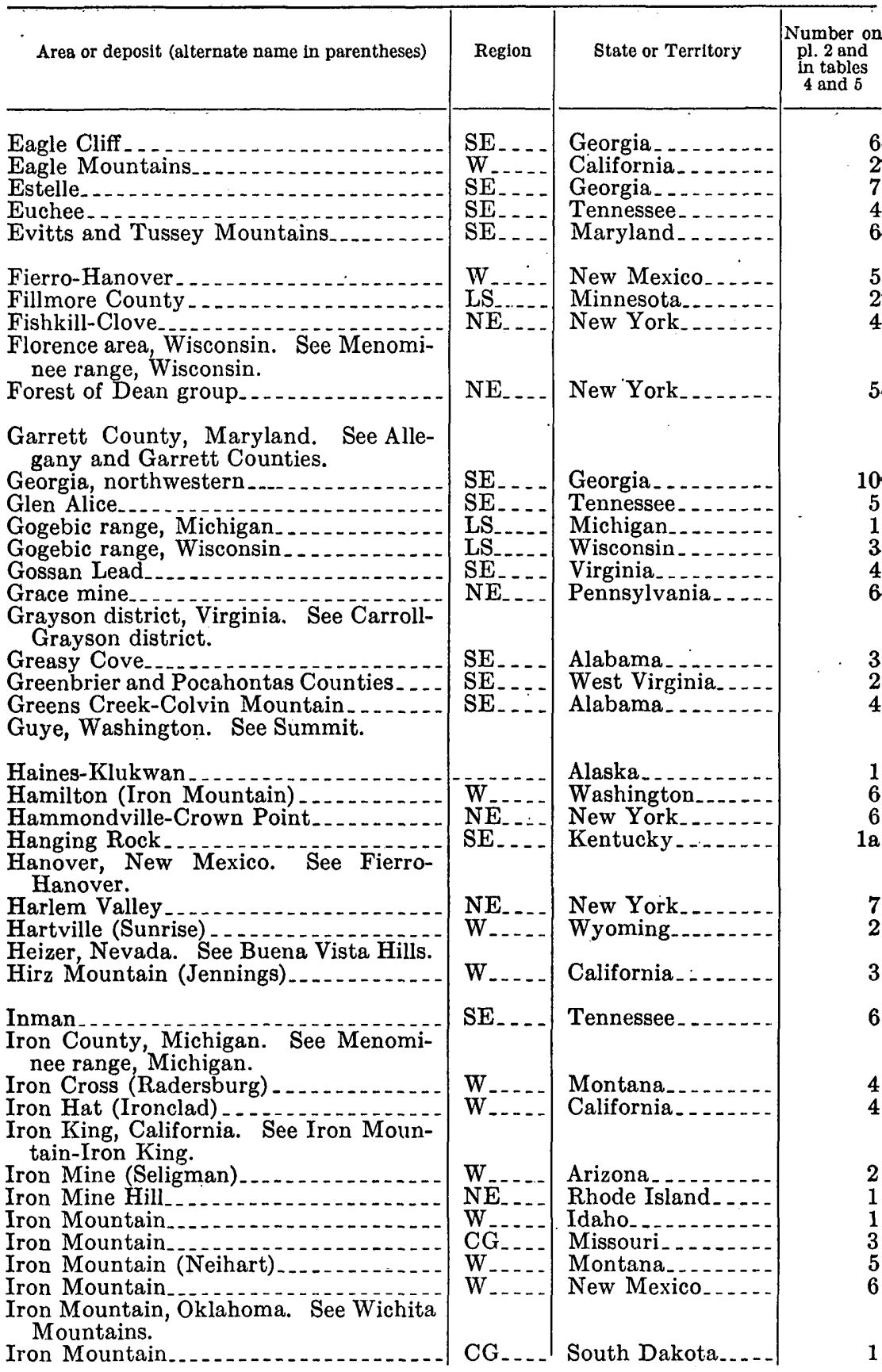


TABLE 6.-Alphabetical list of iron deposits in the United States, including Alaska and Puerto Rico-Continued

[Symbols for regions: CG, central and gulf; LS, Lake Superior; NE, northeastern; SE, southeastern; and W, western].

Area or deposit (alternate name in parentheses)

Iron Mountain, Washington. See Hamilton.

Iron Mountain (Laramie Range)

Iron Mountain-Bessemer (Lava Bed) -.-

Iron Mountain-Iron King (Silver Lake)

Iron Ridge district, Wisconsin. See Mayville-Iron Ridge district.

Iron Springs

Jackson Range, Nevada. See DeLong mine.

Jennings, California. See Hirz Mountain.

Jones

Juncos.

Kasaan Peninsula, Prince of Wales Island

Kentucky Appalachian region, northeastern.

Kingston

Klukwan, Alaska. See Haines-Klukwan.

Knap of Reeds (Camp Butner)

Lafayette County

LaFollette area, Tennessee. See Tennessee, northeastern.

Lake Lawtonka area

Lake Sanford

Laramie Range, Wyoming. See Iron Mountain and Shanton.

Lava Bed, California. See Iron Mountain-Bessemer.

Lawtonka area, Oklahoma. See Lake Lawtonka area.

Lee-Wise district.

Little Sawmill Creek

Livingston County, Kentucky. See Trigg County.

Lookout Mountain area.

Lookout Mountain plateau

Lyon County, Kentucky. See Trigg County.

Lyon Mountain belt

Magnet Cove...Mamie, Alaska. See Kasaan Peninsula. Marquette range.......... Marshall County, southeastern part...Mayagüez Mesa

Mayville-Iron Ridge district _.........McKim Creek, Idaho. See Poison and McKim Creeks.

Menominee range, Michigan

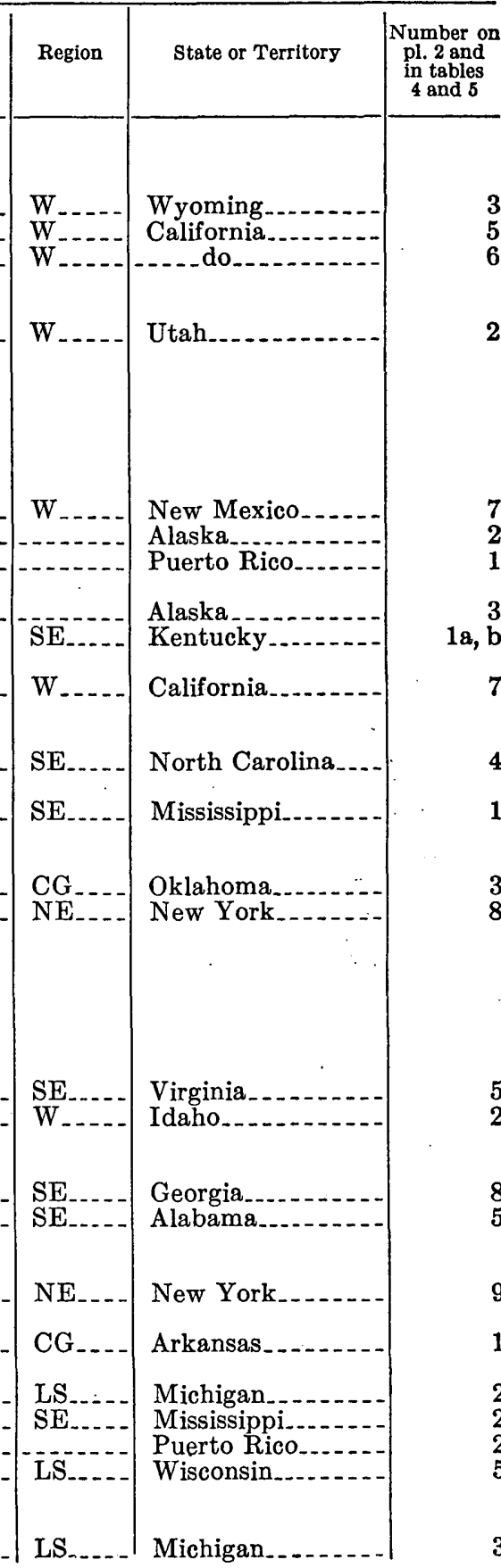


TABLE 6.-Alphabetical list of iron deposits in the United States, including Alaska and Puerto Rico-Continued

[Symbols for regions: CG, central and gulf; LS, Lake Superior; NE, northeastern; 8E, southeastern; and W, western]

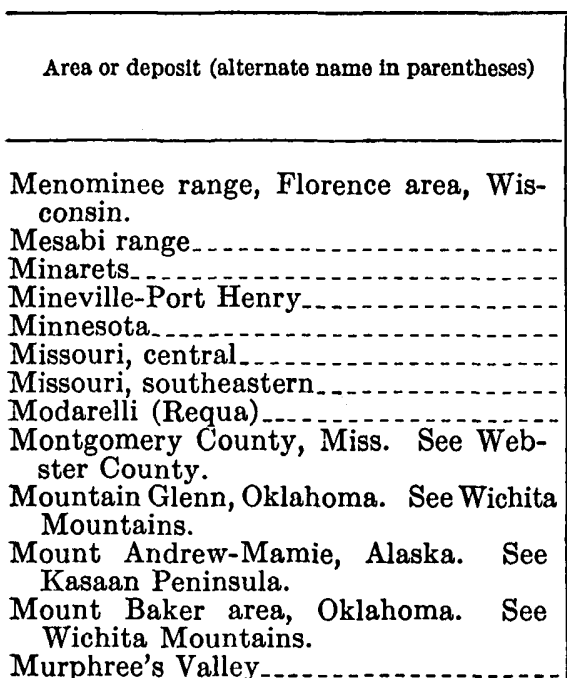

Neihart, Montana. See Iron Mountain.

New England-Wildwood.

New Planet

New York, west-central.

North Basin

North Chattanooga

Ogden mines

Ohio, southeastern

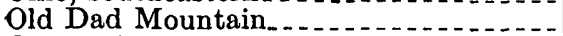

Ooltewah

Orient-Bennett.......

Orogrande...........

Oxford mines

Pea Ridge.

Pennsylvania, central, hematite area

Pennsylvania, central, limonite area other than Scotia.

Pennsylvania, western . . . . . . . .

Phelps Stokes

Pikes Peak ........

Planet, Arizona. See New Planet.

Pocahontas County, W. Va. See Greenbrier and Pocahontas Counties.

Poison and McKim Creeks ............

Poor Man, Alaska. See Kasaan Peninsula.

Port Henry, New York. See MinevillePort Henry.

Prince of Wales Island, Alaska. See Jumbo Basin and Kasaan Peninsula.

Pudding Ridge

Pulaski-Smyth district.

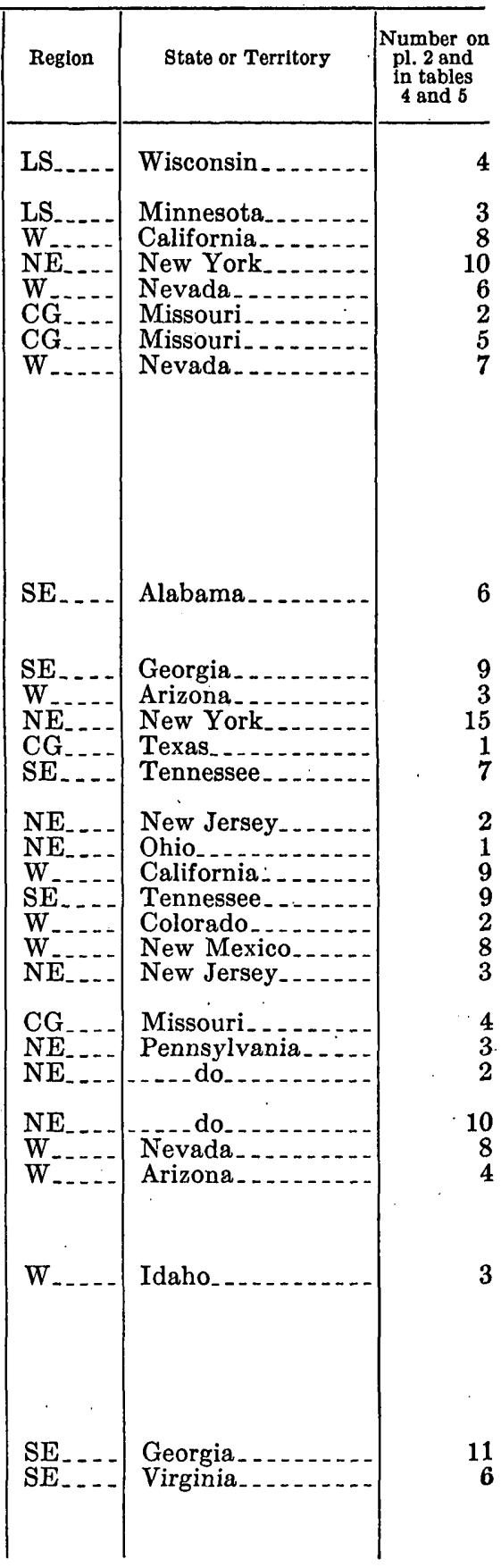

Radersburg, Montana. See Iron Cross.

Read, Washington. See Deer Trail. 
TABLE 6.-Alphabetical list of iron deposits in the United States, including Alaska and Puerto Rico-Continued

[Symbols for regions: CG, central and gulf; LS, Lake Superior; NE, northeastern; SE, southeastern; and W, western]

Area or deposit (alternate name in parentheses)
Red Cliff-Battle Mountain
Requa, Nevada. See Modarelli.
Ringwood district...
Rising Fawn.
Rittenhouse Gap.
Rockwood-Cardiff.
Rose Run area
Running Wolf (Stanford)
Russellville.-.
St. Lawrence County, southeastern, ex-
cept Benson mines.

Sanford, New York. See Lake Sanford.

San Gabriel Mountains.

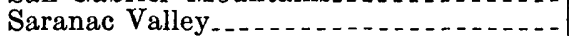

Satterfield Homestead (Tolman)

Scappoose.

Scotia

Segerstrom-Heizer, Nevada. See Buena Vista Hills.

Seligman, Ariz. See Iron Mine.

Shanton (Laramie Range)

Shasta-California

Sheep Creek (White Sulphur Springs)

Shinbone Ridge

Silver Lake, California. See Iron Mountain-Iron King.

Slate Creek area

Smyth district, Virginia. See PulaskiSmyth district.

Snettisham.

South Basin

Southeast Missouri

South Fork Mountain

Southern Cross....................

Springfield mine

Springville-Whitney Stanford, Montana. See Running Wolf.

Stanford, Montana. See Running Wolf.

Sterling Lake

Sterling-Ringwood, New York-New Jersey. See Sterling Lake and Ringwood district.

Stokes, Nevada. See Phelps Stokes.

Sullivan, Missouri. See Bourbon-Sullivan.

Sumas Mountain.

Summit (Denny and Guye)

Sunrise, Wyoming. See Hartville.

Swamp Creek Mountain, Arizona. See Apache.

Sycamore-Bear Canyon.

Talladega.

Taylor Peak

Taylor Ridge.

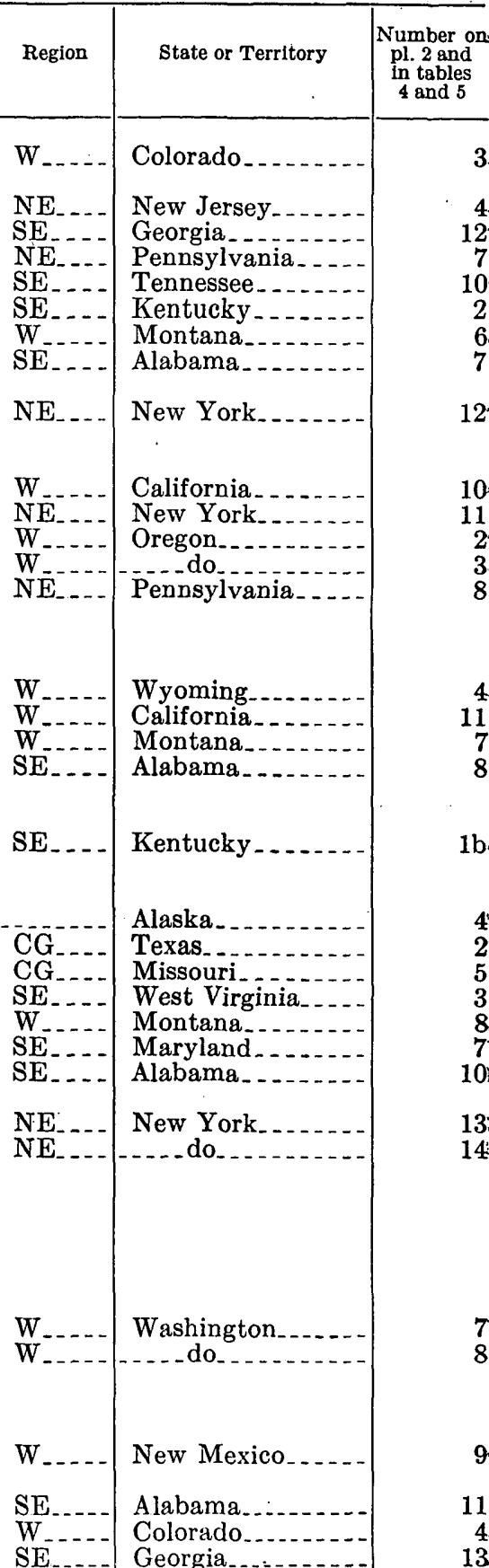


ГABLE 6.-Alphabetical list of iron deposits in the United States, including Alaska and Puerto Rico-Continued

[8ymbols for regions: CQ, central and gulf; LS, Lake Superior; NE, northeastern; SE, southeastern; and W, western]

\begin{tabular}{|c|c|c|c|}
\hline Area or deposit (alternate name in parentheses) & Region & State or Territory & $\begin{array}{l}\text { Number on } \\
\text { pl. } 2 \text { and } \\
\text { in tables } \\
4 \text { and } 5\end{array}$ \\
\hline Tennessee, eastern & SE. & Tennessee... & 3 \\
\hline $\begin{array}{l}\text { Tennessee, northeastern, including La- } \\
\text { Follette area. }\end{array}$ & SE. & $-\ldots$ do & 8 \\
\hline $\begin{array}{l}\text { Thompson, Washington. See Deep } \\
\text { Lake. }\end{array}$ & & & \\
\hline $\begin{array}{l}\text { Tolley ore bank } \\
\text { solman, Oregon. See Satterfield Home- } \\
\text { stead. }\end{array}$ & SE. & Maryland.... & 8 \\
\hline $\begin{array}{l}\text { Tolstoi Mountain, Alaska. See Kasaan } \\
\text { Peninsula. }\end{array}$ & & & \\
\hline $\begin{array}{l}\text { Trigg, Lyon, Livingston, and Crittenden } \\
\text { Counties. }\end{array}$ & SE & Kentucky - & 3 \\
\hline Tuscarawas County and adjacent areas. & $\mathrm{NE}$ & Ohio. & 2 \\
\hline $\begin{array}{l}\text { Tussey Mountain, Maryland. See } \\
\text { Evitts and Tussey Mountains. }\end{array}$ & & & \\
\hline Valley River belt & SE & North Carolina & 5 \\
\hline Vera Cruz & $\mathrm{NE}$ & Pennsylvania & 9 \\
\hline Vermilion range.......... & LS_ & Minnesota. & 4 \\
\hline Vulcan & W & California.. & 12 \\
\hline Waukon. & 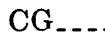 & Iow & 1 \\
\hline $\begin{array}{l}\text { Webster County and borders of Mont- } \\
\text { gomery and Choctaw Counties. }\end{array}$ & SE & Mississ & 3 \\
\hline West Virginia, central & SE. & West Virg & 1 \\
\hline Western Highland Rim. & $\mathrm{SE}$ & Tennesse & 11 \\
\hline White Rocks.... & $\mathrm{NE}_{-} \ldots$ & Pennsylvania.. & 11 \\
\hline $\begin{array}{l}\text { White Sulphur Springs, Montana. See } \\
\text { Sheep Creek. }\end{array}$ & & & \\
\hline $\begin{array}{l}\text { Whitney, Alabama. See Springville- } \\
\text { Whitney. }\end{array}$ & & & \\
\hline $\begin{array}{l}\text { Wichita Mountains (Iron Mountain- } \\
\text { Mountain Glenn-Mount,Baker area). } \\
\text { Wildwood, Georgia. See New England- } \\
\text { Wildwood. }\end{array}$ & $\mathrm{CG}$. & Oklahoma... & 4 \\
\hline Wills Mountain & SE. & Maryland.. & 9 \\
\hline $\begin{array}{l}\text { Wills Valley, northwest and southeast } \\
\text { sides. }\end{array}$ & SE & Alabama.. & 12,13 \\
\hline $\begin{array}{l}\text { Wise district, Virginia. See Lee-Wise } \\
\text { district. }\end{array}$ & & & \\
\hline $\begin{array}{l}\text { Woodstock- } \\
\text { Woodstock-Bucksvi }\end{array}$ & SE. & Alabama...... & 14 \\
\hline Woodstock-Bucksvil & SE. & ...... do & 15 \\
\hline
\end{tabular}




\section{SELECTED BIBLIOGRAPHY}

Aldrich, H. R., 1929, The geology of the Gogebic iron range of Wisconsin: Wisconsin Geol. and Nat. History Survey Bull. 71, Econ. Ser. 24, 279 p.

Allsman, P. T., 1948, Investigation of iron-ore reserves of Iron County, Utah: U.S. Bur. Mines Rept. Inv. 4388, 3 p. (Supplement to U.S. Bur. Mines Rept. Inv. 4076, by Young, W. E., 1947.)

American Metal Market, 1955, National Lead Co. expands reserves of titanium ore, v. 62 , no. 192, p. 1,17 .

Attaya, J. S., 1952, Lafayette County iron ores: Mississippi Geol. Survey Bull. 74, $26 \mathrm{p}$.

Bacon, W. R., 1954, Iron ores of the Pacific Northwest: Western Mtner and Oil Rev., v. 27, no. 8, p. 38-41.

Bain, H. F., 1945, A pattern for western steel production: U.S. Bur. Mines Inf. Circ. $7315,35 \mathrm{p}$.

Ball, S. H., 1907, The Hartville iron-ore range, Wyoming: U.S. Geol. Survey Bull. 315-D, p. 190-205.

Ballinger, H. J., and Pesonen, Paul, 1948, Investigation of southeast Missouri secondary limonite deposits, Wayne, Butler, and Ripley Counties, Missouri : U.S. Bur. Mines Rept. Inv. 4314, 46 p.

Balsley, J. R., Jr., 1943, Vanadium-bearing magnetite-ilmenite deposits near LakeSanford, Essex County, New York: U.S. Geol. Survey Bull. 940-D, p. 99-123.

Bardill, J. D., 1947a, Magnetic surveys, Dannemora magnetite district, Clinton County, New York: U.S. Bur. Mines Rept. Inv. 4002, 7 p.

1947b, Magnetic surveys, Redford-Clayburg magnetite district, Saranac and Black Brook, Clinton County, New York: U.S. Bur. Mines Rept. Inv. 4003, 6 p. (For supplement, see Reed, D. F., and Cohen, C. J., 1949.)

-1947c, Magnetic surveys, Russian Station magnetite district, Clinton County, New York : U.S. Bur. Mines Rept. Inv. 4008, 7 p.

Barnes, V. E., Goldich, S. S., and Romberg, Frederick, 1949, Iron ore in the Llano region, central Texas: Texas Univ. Bur. Econ. Geology Rept. Inv. $5,50 \mathrm{p}$.

Bayley, W. S., 1904, The Menominee iron-bearing district of Michigan: U.S. Geol. Survey Mon. 46, 513 p.

1910, Iron mines and mining in New Jersey: New Jersey Geol. Surveyr Final Rept. Ser., v. 7, 512 p.

- 1922, General features of the magnetite ores of western North Carolina and eastern Tennessee: U.S. Geol. Survey Bull. 735-G, p. 209-270.

1923, The magnetic iron ores of east Tennessee and western North Carolina: North Carolina Geol. and Econ. Survey Bull. 32, 252 p.

- 1925, Deposits of brown iron ores (brown hematite) in western North Carolina: North Carolina Geol. and Econ. Survey Bull. 31, 76 p.

Bean, E. F., 1949, Iron ore resources of Wisconsin: Skillings' Mining Rev., v. 38 , no. 8, p. 1, 4, 11.

Behre, C. H., Jr., Osborn, E. F., and Rainwater, E. H., 1936, Contact ore deposition at the Calumet iron mine of Colorado: Econ. Geology, v. 31, no. 8, p. 781-804.

Bengston, R. G., Moore, D. D., Ramsey, R. H., and Lund, R. J., 1950, Survey report on mineral resources of southeastern Ohio to the Southeastern Ohio Regional Council: Ohio Dept. Nat. Res., Div. Geol. Survey, 108 p. 
Bishop, O. M., 1952, Mineral resources of Missouri in the Arkansas and White River Basins-preliminary report: U.S. Inter-Agency Comm. on the Arkansas-White-Red River Basins, Minerals and Geology Work Group, $34 \mathrm{p}$.

Blondel, Fernand, and Lasky, S. G., 1955, Concepts of mineral reserves and resources, in Survey of world iron ore resources-Occurrence, appraisal and use: Dept. Econ. and Social Affairs, United Nations, United Nations Publ. Sales No. 1954.II.D.5, p. 169-174.

1956, Mineral reserves and mineral resources: Econ. Geology, v. 51, no. 7, p. 686-697.

Botsford, G. B., and Mosier, McHenry, 1948, West Portal magnetite mines, Hunterdon County, New Jersey : U.S. Bur. Mines Rept. Inv. 4352, 11 p.

Boyd, C. R., 1897, Grayson County, Virginia: Independence, Va., Creek D. Brown, publisher, $24 \mathrm{p}$.

Boyum, B. H., 1954, The geology of the Marquette iron range, in Fourth mining geology symposium: Minneapolis, Minnesota Univ., Center for Continuation Study, p. 3-8.

Broughton, W. A., 1943a, The Blewett iron deposit, Chelan County, Washington, with preliminary tonnage estimates: Washington Div. Geology Rept. Inv. $10,21 \mathrm{p}$.

- 1943b, The Buckhorn iron deposits of Okanogan County, Washington, Results of a magnetic survey: Washington Div. Geology Rept. Inv. 8, 21 p.

- 1944, Economic aspects of the Blewett-Cle Elum iron ore zone, Chelan and Kittitas Counties, Washington: Washington Div. Geology Rept. Inv. 12, $42 \mathrm{p}$.

1945, Some magnetite deposits of Stevens and Okanogan Counties, Washington: Washington Div. Geology Rept. Inv. 14, 24 p.

Brown, Andrew, 1948, North Alabama brown iron ores: U.S. Bur. Mines Rept. Inv. $4229,82 \mathrm{p}$.

Brown, D.: I., 1953, Taconite-Mesabi's answer to the iron ore shortage (Minnesota) : Iron Age, v. 171, no. 11, p. 127-134.

Brown, W. F., 1953, Metals and nonmetallic minerals in Arkansas-preliminary report: U.S. Inter-Agency Comm. on the Arkansas-White-Red River Basins, Minerals and Geology Work Group, p. 27-29.

Buddington, A. F., and Chapin, Theodore, 1929, Geology and mineral deposits of southeastern Alaska: U.S. Geol. Survey Bull. 800, 398 p.

Buddington, A. F., and Leonard, B. F., 1949, Memorandum on the geology of the Crown Point, New York, group of magnetite deposits : U.S. Geol. Survey open-file report, $22 \mathrm{p}$.

Burchard, E. F., 1907, The brown ores of the Russellville district, Alabama: U.S. Geol. Survey Bull. 315-D, p. 152-160.

1909, Tonnage estimates of Clinton iron ore in the Chattanooga region of Tennessee, Georgia, and Alabama: U.S. Geol. Survey Bull. 380-E, p. 169-187.

1913, The red iron ores of east Tennessee: Tennessee State Geol. Survey Bull. 16, 173 p.

1914, Preliminary report on the red iron ores of east Tennessee, northeast Alabama, and northwest Georgia: U.S. Geol. Survey Bull. 540-G, p. 279-328.

1915, Iron-bearing deposits in Bossier, Caddo, and Webster parishes, Louisiana : U.S. Geol. Survey Bull. 620-G, p. 129-150. 
Burchard, E. F., 1931, Iron ore on Canyon Creek, Fort Apache Indian Reservatior, Arizona : U.S. Geol. Survey Bull. 821-C, p. 51-75.

1932, The Birmingham district; Alabama, in Mining districts of the eastern States: Internat. Geol. Cong., 16th, United States, 1933, Guidebook 2, p. 113-125.

1933, The sources of our iron ores: Jour. Chem. Education, v. 10, no. 4, p. $195-204$, no. 5, p. 288-296.

1934, The brown iron ores of the Western Highland Rim, Tennessee: Tennessee State Geol. Survey Bull. 39, $227 \mathrm{p}$.

1938, Iron ore available to Alabama blast furnaces: Mining and Metallurgy, v. 19, p. 183-184.

1941, Manganiferous and ferruginous chert in Perry and Lewis Counties, Tennessee: U.S. Geol. Survey Bull. 928-D, p. 223-273.

1948, Summary of the iron-ore situation in California, pt. N of Iron Resources of California: California Dept. Nat. Resources, Div. Mines Bull. 129 , p. 208-229.

Burchard, E. F. and Andrews, T. G., 1947, Iron ore outcrops of the Red Mountain formation in northeast Alabama: Alabama Geol. Survey Spec. Rept. $19,375 \mathrm{p}$.

Burchard, E. F., and Butts, Charles, 1910, Iron ores, fuels, and fluxes of the Birmingham district, Alabama, with chapters on origin of the ores, by $\mathbf{E}$. C. Eckel : U.S. Geol. Survey Bull. 400, 204 p.

Burchard, E. F., Johnson, A. C., and Melcher, N. B., 1947, Iron ore, in Mineral position of the United States, Appendix to Hearings before the National Resources Economic Subcommittee of the Committee on Public Lands of the Senate: U.S. 80th Cong., 1st sess., p. 251-254.

Burgess, R. J., and Sanford, R. S., 1949, Investigation of Cheever limonite deposit, Berkshire County, Massachusetts: U.S. Bur. Mines Rept. Inv. 4423, $13 \mathrm{p}$.

Butler, A. P., Jr., 1945, Dayton iron deposit, Lyon County, Nevada : U.S. Geol. Survey prelim. rept., $9 \mathrm{p}$.

Butts, Charles, and Moore, E. S., 1936, Geology and mineral resources of the Bellefonte quadrangle, Pennsylvania: U.S. Geol. Survey Bull. 855, 111 p.

Carr, M. S., 1952, Iron deposits of Puerto Rico, in Symposium sur les gisements de fer du monde: Internat. Geol. Cong., 19th, Algiers, v. I, p. 423-426.

Carr, M. S., and Pesonen, P. E., 1952, Iron ore-A test for technology, in Resources for freedom, a report to the President by the President's Materials Policy Commission, v. 2, The outlook for key commodities: Washington, U.S. Govt. Printing Office, p. 146-148.

Chase, G. W., 1950a, Geologic map of basic igneous rocks in the Raggedy Mountains, Wichita Mountain system, Oklahoma: Oklahoma Geol. Survey Map A-1.

- 1950b, Titaniferous magnetite in basic igneous rocks of the Wichita Mountains, Oklahoma: Oklahoma Geol. Survey prelim. rept., 12 p.; also Hopper, v. 11, no. 2, p. 11-20.

- 1952, Ilmenite in alluvial sands of the Wichita Mountain system, Oklahoma, Oklahoma Geol. Survey Circ. 30, 44 p.

Chute, N. E., 1945, The brown iron ore district of Berkshire County, Massachusetts : U.S. Geol. Survey open-file report, 39 p.

Clark, E. L., and Muilenburg, G. A., 1954, The brown iron ore resources of Missouri : Mining Eng., v. 6, no. 1, p. 63-66. 
Clements, J. M., 1903, The Vermilion iron-bearing district of Minnesota : U.S. Geol. Survey Mon. 45, $463 \mathrm{p}$.

Clements, J. M., and Smyth, H. L., 1899, The Crystal Falls iron-bearing district of Michigan (with a chapter on the Sturgeon River tongue, by W. S. Bayley) : U.S. Geol. Survey Mon. 36, $512 \mathrm{p}$.

Colony, R. J., 1923, The magnetite iron deposits of southeastern New York: New York State Mus. Bull. 249-250, 161 p.

Colony, R. J., and Meyerhoff, H. A., 1935, The magnetite deposit near Humacao, Puerto Rico: Am. Inst. Mining Metall. Engineers Trans., v. 115, (Mining geology), p. 247-272.

Connolly, J. P., and O'Harra, C. C., 1929, Iron ore, in The mineral wealth of the Black Hills : South Dakota School Mines Bull. 16, p. 212-218.

Cook, K. L., 1950, Magnetic surveys in the Iron Springs district, Iron County, Utah : U.S. Bur. Mines Rept. Inv. 4586, $78 \mathrm{p}$.

Cooledge, C. W., and Overspeck, L. S., 1909, The iron deposits of the Black Hills, South Dakota : Min. Sci., v. 60, p. 319-321.

Crane, G. W., 1912, The iron ores of Missouri: Missouri Bur. Geology and Mines, v: 10, $2 d$ ser., $434 \mathrm{p}$.

Crawford, A. L., and Buranek, A. M., 1952, Utah iron deposits other than those of Iron and Washington Counties, Utah : Utah Geol. and Mineralog. Survey Circ. 24, $17 \mathrm{p}$.

Crosby, I. B., 1932, Report on the mineral resources of Massachusetts; a survey of the literature: Massachusetts Indus. Devel. Comm., $35 \mathrm{p}$.

Crouse, C. S., and Wyatt, J. L., 1948, A preliminary report on the iron ore resources of Kentucky : Kentucky Univ., Eng. Expt. Sta. Bull. ser., v. 3, no. 1, Eng. Research Bull. 9, p. 5-31.

Crowell \& Murray, Inc., 1930, The iron ores of Lake Superior: Cleveland, Ohio, The Penton Press Co., 332 p.

Cumings, W. L., 1932, The Cornwall iron mines, near Lebanon, Pennsylvania, in Mineral deposits of New Jersey and eastern Pennsylvania : Internat. Geol. Cong., 16th, United States 1933, Guidebook 8, p. 48-54.

Cummings, J. B., 1946, Exploration of New Planet iron deposit, Yuma County, Arizona: U.S. Bur. Mines Rept. Inv. 3982, 37 p.

Davis, E. W., 1947, Iron-ore reserves of the Lake Superior district: Mining and 'Metallurgy, v. 28, no. 481, p. 15-18.

- 1950, Mining iron ore-Beneficiation and reserves, in The $\triangle B C$ of iron and steel, 6th ed.: Cleveland, Ohio, The Penton Publishing Co., p. 1-15.

DeMunck, V. C., 1956, Iron deposits in Montana: Montana Bur. Mines and Geology Inf. Circ. 13, 49 p.

Diemer, R. A., 1941, Titaniferous magnetite deposits of the Laramie Range, Wyoming: Wyoming Geol. Survey Bull. 31, 23 p.

Dupuy, L. W., and Ballinger, H. J., 1949, Filled-sink iron deposits in Crawford, Dent, Franklin, and Texas Counties, Missouri : U.S. Bur. Mines Rept. Inv. $4452,23 \mathrm{p}$.

Durrell, Cordell, and Proctor, P. D., 1948, Iron-ore deposits near Lake Hawley and Spencer Lakes, Sierra County, California, pt. L of Iron Resources of California: California Dept. Nat. Resources, Div. Mines Bull. 129, p. 166-192.

Dutton, C. E., 1952, Memorandum on iron deposits in the United States of America, in Symposium sur les gisements de fer du monde: Internat. Geol. Cong., 19th, Algiers, v. 1, p. 371-411. 
Dutton, C. E., 1955, Iron-ore deposits of North America and the West Indies, in Survey of world iron ore resources-occurrence, appraisal and use: Dept. Econ. and Social Affairs, United Nations, United Nations Pub., Sales No. 1954. II.D.5, p. 179-208.

Dutton, C. E., and Carr, M. S., 1947, Iron-ore deposits of the Western United States: U.S. Geol. Survey Strategic Mins. Inv. Prelim. Map 3-212.

Eakin, H. M., 1915, Iron-ore deposits near Nome: U.S. Geol. Survey Bull. 622-I, p. $351-365$.

Eby, J. B., 1923, Clinton iron ores of Wise County, Virginia, in The geology and mineral resources of Wise County and the coal-bearing portion of Scott County, Virginia: Virginia Geol. Survey Bull. 24, p. 545-569.

Eckel, E. B., 1938, The brown iron ores of eastern Texas: U.S. Geol. Survey Bull. $902,157 \mathrm{p}$.

Eckel, E. C., 1905, Limonite deposits of eastern New York and western New England: U.S. Geol. Survey Bull 260, p. 335-342.

1906, The Oriskany and Clinton iron ores of Virginia: U.S. Geol. Survey Bull. 285, p. 183-189.

1914, Iron ores; their occurrence, valuation, and control: New York, McGraw-Hill Book Co., 430 p.

Eilertsen, N. A., 1952, Maple Mountain-Hovey Mountain manganese project, central district, Aroostook County, Maine : U.S. Bur. Mines Rept. Inv. 4921, $118 \mathrm{p}$.

Emmons, W. H., and Grout, F. F., 1943, Iron, in Mineral resources of Minnesota : Minnesota Geol. Survey Bull. 30, p. 13-57.

Engineering and Mining Journal, 1957, St. Joe and Bethlehem study Missouri iron find: v. 158 , no. 4, p. 72.

Entwistle, L. P., 1944, Manganiferous iron-ore deposits near Silver City, New Mexico: New Mexico School Mines, State Bur. Mines and Min. Res. Bull. 19, $70 \mathrm{p}$.

Erickson, A. W., 1948, Investigation of Tolstoi Mountain iron deposits, Kasaan Peninsula, Prince of Wales Island, southeastern Alaska: U. S. Bur. Mines Rept. Inv. 4373, 5 p.

Espenshade, G. H., 1952, Preliminary report on manganese, iron and barite deposits of the James River-Roanoke River district, Virginia: U.S. Geol. Survey Mineral Inv. Map MF 5.

Evans, A. M., 1947, Central Texas (Llano) iron deposits, Llano and Mason Counties, Texas : U.S. Bur. Mines Rept. Inv. 4045, 16 p.

Evans, A. M., and Soule, J. H., 1947, Rusk iron depasits, Cherokee County, Texas: U.S. Bur. Mines Rept. Inv. 4115, 15 p.

Farnham, L. L., and Havens, R., 1957, Pikes Peak iron deposits, Maricopa County, Arizona: U.S. Bur. Mines Rept. Inv. 5319, 31 p.

Fettke, C. R., and Hubbard, Bela, 1920, The limonite deposits of Mayagüez Mesa, Porto Rico: Am. Inst. Mining Metall. Engineers Trans., v. 61, p. 97-112.

Fix, G. F., 1938, Mineral resources of Indiana-Iron : Indiana Dept. Conserv., 3 p.

Foose, R. M., 1945a, Iron ores of the Cumberland Valley and their future: Pennsylvania Dept. Int. Affairs Monthly Bull., v. 13, no. 5, p. 3-13.

- 1945b, Iron-manganese ore deposit at White Rocks, Cumberland County, Pennsylvania: Pennsylvania Geol. Survey, 4th ser., Bull. M-26, 35 p.

Forbes, J. M., 1956, Iron ore: U.S. Bur. Mines Minerals Yearbook, 1955, v. 1, p. 545-574.

Freeman, V. L., 1954, Geology of part of the Johnny Gulch quadrangle, Montana : U.S. Geol. Survey open-file report, 57 p. 
Frey, Eugene, 1946a, Exploration of Iron Mountain titaniferous magnetite deposits, Albany County, Wyoming: U.S. Bur. Mines Rept. Inv. 3968, 37 p.

1946b, Exploration of the Shanton iron-ore property, Albany County, Wyoming: U.S. Bur. Mines Rept. Inv. 3918, 5 p.

1947a, Good Fortune iron mine, Platte County, Wyoming: U.S. Bur. Mines Rept. Inv. 4089, $7 \mathrm{p}$.

1947b, Hartville iron district, Platte County, Wyoming: U.S. Bur. Mines Rept. Inv. 4086, 3 p.

Furcron, A. S., 1935, James River iron and marble belt, Virginia : Virginia Geol. Survey Bull. 39, $124 \mathrm{p}$.

Furcron, A. S., and Ray, D. L., 1957, Clayton iron ores of Webster County, Georgia: Georgia Geol. Survey, Georgia Mineral Newsletter, v. 10, no. 3, p. 73-76. (Includes geologic map of Webster County, Georgia, showing location of iron-ore deposits.)

Geehan, R. W., 1949, Investigation of the Dayton iron deposit, Lyon and Storey Counties, Nevada: U.S. Bur. Mines Rept. Inv. 4561, 34 p.

Gillette, Tracy, 1947, The Clinton of western and central New York: New York State Mus. Bull. 341, 191 p.

Glover, S. L., 1942, Washington iron ores, a summary report: Washington Div. Mines and Mining Rept. Inv. 2, $23 \mathrm{p}$.

Goddard, E. N., Warner, L. A., and Walton, M. S., Jr., 1944, Copper-bearing iron deposits of the Mount Andrew-Mamie area, Kasaan Peninsula, Prince of Wales Island, southeastern Alaska: U.S. Geol. Survey prelim. rept., $29 \mathrm{p}$.

Goldich, S. S., and Wedow, Helmuth, Jr., 1943, Preliminary report on the magnetic iron ores of western North Carolina and eastern Tennessee: U.S. Geol. Survey open-flle report, $47 \mathrm{p}$.

Gooch, E. O., 1954, Iron in Virginia: Virginia Div. Geology, Mineral Resources Circ. 1, $17 \mathrm{p}$.

Goodspeed, G. E., 1946a, Preliminary report on iron-ore deposits adjacent to Belt Creek, Meagher County, Montana: U.S. Geol. Survey open-file report, $8 \mathrm{p}$.

- 1946b, Preliminary report on iron deposits of Running Wolf district, Judith Basin County, Montana, U.S. Geol. Survey open-file report, $26 \mathrm{p}$.

1946c, Preliminary report on iron-ore deposits near White Sulphur Springs, Meagher County, Montana: U.S. Geol. Survey open-file report, $15 \mathrm{p}$.

1946d, Preliminary report on iron-ore deposits adjacent to Yogo Peak, Judith Basin County, Montana: U.S. Geol. Survey open-file report, 11 p.

Grantham, R. M., and Soulé J. H., 1947, Jones iron deposit, Socorro County, New Mexico: U.S. Bur. Mines Rept. Inv. 4010, 4 p.

Grantz, Arthur, 1956, Magnetite deposits at Tuxedni Bay, Alaska: U.S. Geol. Survey Bull. 1024-D, p. 95-106.

Grimsley, G. P., 1909, Iron ores, salt, and sandstones: West Virginia Geol. Survey $\nabla .4,595 \mathrm{p}$.

Grout, F. F., 1926, The geology and magnetite deposits of northern St. Louis County, Minnesota: Minnesota Geol. Survey Bull. 21, 220 p.

1949-1950, The titaniferous magnetites of Minnesota: St. Paul, Minn., Iron Range Resources and Rehabilitation Comm., $117 \mathrm{p}$.

Grout, F. F., and Broderick, T. M., 1919, The magnetite deposits of the eastern Mesabi range, Minnesota: Minnesota Geol. Survey Bull. 17, 58 p.

Grout, F. F., and Wolff, J. F., Sr., 1955, The geology of the Cuyuna district, Minnesota : Minnesota Geol. Survey Bull. 36, 144 p.

Gruner, J. W., 1946, The mineralogy and geology of the taconites and iron ores 
of the Mesabi range, Minnesota : St. Paul, Minn., Iron Range Resources and' Rehabilitation Comm., 127 p.

Gruner, J. W., 1950, An appraisal of the iron-ore resources of the world-an American estimate: Am. Inst. Mining Metall. Engineers Blast Furnace,-Coke Oven and Raw Materials Committee, Iron and Steel Division Proc., 1950, p. 4-17. 1954, A realistic look at taconite estimates: Mining Eng., v. 6 no. 3, p. 287-288.

Hadley, J. B., 1945, Iron-ore deposits in the eastern part of the Eagle Mountains, Riverside County, California, pt. A of Iron Resources of California : California Dept. Nat. Resources, Div. Mines Bull. 129, p. 3-24.

Harder, E. C., 1909a, The iron ores of the Appalachian region in Virginia : U.S. Geol. Survey Bull. 380, p. 215-254.

1909b, The Taylor Peak and Whitepine iron-ore deposits, Colorado: U.S. Geol. Survey Bull. 380, p. 188-198.

- 1917, Manganiferous iron ores of the Cuyuna district, Minnesota: Am. Inst. Mining Metall. Engineers Bull., v. 129, p. 1313-1344; 1918, Trans. v. 58, p. 453-486.

Hart, Charles, 1939, Known iron ore reserves of the world and their significance : Iron and Steel Engineer, v. 16, no. 5, p. 42-61.

Haseltine, R. H., 1924, Iron ore deposits of Georgia: Georgia Geol. Survey Bull. 41, $222 \mathrm{p}$.

Hawkes, H. E., Jr., and Hotz, P. E., 1947, Drill-hole correlation as an aid in exploration of magnetite deposits of the Jersey Highlands, New York and New Jersey : U.S. Geol. Survey Bull. 955-A, p. 1-17.

Hawkes, H. E., Jr., Wedow, Helmuth, and Balsley, J. R., 1953, Geologic investigation of the Boyertown magnetite deposits in Pennsylvania: U.S. Geol. Survey Bull. 995-D, p. 135-148.

Hayes, C. W., 1909, Iron ores of the United States: U.S. Geol. Survey Bull. 394, p. 70-113.

Hayes, W. C., 1957, Exploration and development of the sedimentary iron ores: of Missouri : Missouri Div. Geol. Survey and Water Resources Inf. Circ., 33 p.

Hewett, D. F., 1948, Iron deposits of the Kingston Range, San Bernardino. County, California, pt. M of Iron Resources of California: California Dept. Nat. Resources, Div. Mines Bull. 129, p. 194-206.

Hickok, W. O., IV, 1933, The iron ore deposits at Cornwall, Pennsylvania: Econ. Geology, v. 28, no. 3, p. 193-255.

1939, Iron ores of Pennsylvania: Pennsylvania Geol. Survey, 4th ser., Bull. M 18-B, p. 1-21.

Hild, J. H., 1953, Diamond drilling on the Shanton magnetite-ilmenite deposits, Albany County, Wyoming: U.S. Bur. Mines Rept. Inv. 5012, 7 p.

Hobbs, W. H., 1907, The iron ores of the Salisbury district of Connecticut, New York, and Massachusetts : Econ. Geology, v. 2, p. 153-181.

Hodge, E. T., 1935, Iron ores of Oregon, in Report on available raw materials: for a Pacific coast iron industry: Portland, Oreg., U.S. Army, Office Div. Engineer, v. 3, Appendix E-4, 32 p.

-1935-38, Report on available raw materials for a Pacific coast iron industry : Portland, Oreg., U.S. Army, Office Div. Engineer, 5 v.

Holden, R. J., 1906, The brown ores of the New River-Cripple Creek district, Virginia : U.S. Geol. Survey Bull. 285, p. 190-193.

1907, Metallic minerals, iron, in Watson, T. L., Mineral resources of Virginia: Lynchburg, Va., Virginia Jamestown Exposition Commission, p. $402-491$. 
Holden, R. J., 1933, Iron, in Virginia-Econonic and Civic: Richmond, Va., Virginia Polytech, Inst., p. 119-126.

Holt, S. P., and Sanford, R. S., 1946, Exploration of Poor Man iron deposit, Kasaan Peninsula, Prince of Wales Island, southeastern Alaska: U.S. Bur. Mines Rept. Inv. 3956, $8 \mathrm{p}$.

Hotchkiss, W. O., and others, 1933, Lake Superior region: Internat. Geol. Cong., 16th, United States, Guidebook 27, Excursion C-4, 101 p.

Hotz, P. E., 1950, Diamond-drill exploration of the Dillsburg magnetite deposits, York County, Pennsylvania : U.S. Geol. Survey Bull. 969-A, p. 1-27. 1953a, Limonite deposits near Scappoose, Columbia County, Oregon: U.S. Geol. Survey Bull. 982-C, p. 75-93.

1953b, Magnetite deposits of the Sterling Lake, New York-Ringwood, New Jersey, area : U.S. Geol. Survey Bull. 982-F, p. 153-241.

— 1954, Some magnetite deposits in New Jersey: U.S. Geol. Survey Bull. 995-F, p. 201-253.

Howell, J. V., 1916, The iron ore deposits near Waukon, Iowa: Iowa Geol. Survey Ann. Rept. 25 of 1914, p. 33-101.

Ireland, H. A., 1944, Petroliferous iron ore of Pennsylvanian age in eastern Ohio: Am. Assoc. Petroleum Geologists Bull., v. 28, no. 7, p. 1051-1056.

Irving, R. D., and Van Hise, C. R., 1892, The Penokee iron-bearing series of Michigan and Wisconsin ; U.S. Geol. Survey Mon. 19, $534 \mathrm{p}$.

James, H. L., 1954, Geology of the Menominee and Iron River-Crystal Falls districts, Michigan, in Fourth mining geology symposium: Minneapolis, Minnesota Univ., Center for Continuation Study, p. 9-13.

James, H. L., and Dutton, C. E., 1951, Geology of the northern part of Iron River district, Iron County, Michigan: U.S. Geol. Survey Circ. 120, 12 p.

Joesting, H. R., Bacon, L. O., and Getz, J. H., 1948, Geophysical investigation of manganiferous iron deposits, Boston Hill, Grant County, New Mexico: U.S. Bur. Mines Rept. Inv. 4175, 12 p.

Johnson, A. O., and Ricker, Spangler, 1948, Summary of investigations of ironore deposits of California, pt. $O$ of Iron Resources of California : California Dept. Nat. Resources, Div. Mines Bull. 129, p. 233-241.

Johnson, B. L., 1908, Contributions to the geology of Rhode Island-Notes on the history and geology of Iron Mine Hill, Cumberland: Am. Jour. Sci., 4th ser., v. 25, p. 1-12.

Johnston, V. D., 1955, Requirements and potential sources of iron ore for steel plants in the United States projected for 30 years: Skillings' Mining Review, $\nabla .44$, no. 28 , p. 4 (chart).

Jones, J. C., 1913, The Barth iron ore deposit [Nevada] : Econ. Geology, v. 8, p. 247-263.

Julihn, C. E., and Moon, L. B., 1945, Summary of Bureau of Mines exploration projects on deposits of raw material resources for steel production: U.S. Bur. Mines Rept. Inv. 3801, 35 p.

Keith, H. O., and Harte, C. R., 1935, The early iron industry of Connecticut: Connecticut Soc. of Civil Engineers 51st Ann. Rept., 69 p.

Kelley, V. C., 1949, Geology and economics of New Mexico iron-ore deposits: New Mexico Univ. Pubs.:in Geology No. 2, 246 p. 1951, Oolitic iron deposits of New Mexico: Am. Assoc. Petroleum Geologists Bull., v. 35, no. 10, p. 2199-2228.

Kelly, J. V., 1947, Columbia River magnetite sands, Clatsop County, Oregon, and Pacific County, Washington, Hammond and McGowan deposits: U.S. Bur. Mines Rept. Inv. 4011, 7 p. 
Kennedy, G. O., 1953, Geology and mineral deposits of Jumbo Basin, southeastern Alaska : U.S. Geol. Survey Prof. Paper 251, 46 p.

Kesler, T. L., 1950, Geology and mineral deposits of the Cartersville district, Georgia : U.S. Geol. Survey Prof. Paper 224, 97 p.

Killeen, P. L., 1952, Iron deposits of Alaska, in Symposium sur les gisements de fer du monde: Internat. Geol. Cong., 19th, Algiers, v. 1, p. 413-423.

Killeen, P. L., Carr, M. S., and Flint, D. E., 1952, Iron deposits in the territories and overseas possessions of the United States and on certain islands under its jurisdiction, in Symposium sur les gisements de fer du monde: Internat. Geol. Cong., 19th, Algiers, v. 1, p. 413-427.

Kline, M. H., and Ballard, T. J., 1948, Cranberry magnetite deposits, Avery County, North Carolina, and Carter County, Tennessee: U.S. Bur. Mines Rept. Inv. 4274, 85 p.

1949, Investigation of the Great Gossan Lead, Carroll County, Virginia : U.S. Bur. Mines Rept. Inv. 4532,39 p.

Knoerr, A. W., 1952, Minnesota mining men open up rich Puerto Rico iron mine: Eng. Mining Jour., v. 153, no. 8, p. 74-79.

1953, Bethlehem Steel New Grace mine: Eng. Mining Jour., v. 154, no. 1, p. 88-90.

Kral, V. E., 1947a, Buena Vista iron deposit, Churchill County, Nevada: U.S. Bur. Mines Rept. Inv. 4094, 5 p.

1947b, McCoy iron deposit, Lander County, Nevada: U.S. Bur. Mines: Rept. Inv. 3990, 5 p.

1947c, Modarelli iron deposit, Eureka County, Nevada : U.S. Bur. Mines Rept. Inv. 4005, 7 p.

1947d, Phelps Stokes iron deposit, Nye County, Nevada: U.S. Bur. Mines: Rept. Inv. 4000, 6 p.

1947e, Segerstrom-Heizer iron property, Pershing County, Nevada: U.S. Bur. Mines Rept. Inv. 4025, 8 p.

Kreamalmyer, K. L., 1945, Exploration of Silver Hollow, Newbauer, and Coleman iron deposits, Franklin and Crawford Counties, Missouri : U.S. Bur. Mines Rept. Inv. 3870, $10 \mathrm{p}$.

Lake, M. C., 1932, The iron-ore deposits of Iron Mountain, Missouri, in Mining districts of the Eastern States : Internat. Geol. Cong., 16th, United States, 1933, Guidebook 2, p. 56-67.

Lake Superior Iron Ore Association, 1938, Lake Superior iron ores : Cleveland, Ohio, $364 \mathrm{p}$.

1952, Lake Superior iron ores, mining directory and statistical record, 2d ed.: Cleveland, Ohio, $326 \mathrm{p}$.

Lamey, C. A., 1945a, Iron Mountain iron-ore deposits, Lava Bed district, San Bernardino County, California, pt. B of Iron Resources of California : California Dept. Nat. Resources, Div. Mines Bull. 129, p. 27-38.

1945b, Iron Mountain and Iron King iron-ore deposits, Silver Lake district, San Bernardino County, California, pt. C of Iron Resources of California: California Dept. Nat. Resources, Div. Mines Bull. 129, p. 41-58. 1945c, Old Dad Mountain iron-ore deposit, San Bernardino County, California, pt. D of Iron Resources of California: California Dept. Nat. Resources, Div. Mines Bull. 129, p. 61-67.

1945d, Cave Canyon iron-ore deposits, San Bernardino County, California, pt. E of Iron Resources of California : California Dept. Nat. Resources, Div. Mines Bull. 129, p. 71-83. 
Lamey, C. A., 1945e, Vulcan iron-ore deposit, San Bernardino County, California, pt. F of Iron Resources of California : California Dept. Nat. Resources, Div. Mines Bull. 129, p. 87-95.

1945f, Iron Hat (Ironclad) iron-ore deposits, San Bernardino County, California, pt. G of Iron Resources of California: California Dept. Nat. Resources, Div. Mines Bull. 129, p. 99-109.

1945g, Ship Mountains iron-ore deposit, San Bernardino County, California, pt. $\mathrm{H}$ of Iron Resources of California : California Dept. Nat. Resources, Div. Mines Bull. 129, p. 113-116.

1945h, Hirz Mountain iron-ore deposits, Shasta County, California, pt. J of Iron Resources of California: California Dept. Nat. Resources, Div. Mines Bull. 129, p. 130-136.

1945i, Shasta and California iron-ore deposits, Shasta County, California, pt. K of Iron Resources of California : California Dept. Nat. Resources, Div. Mines Bull. 129, p. 138-164.

1950, The Blewett iron-nickel deposit, Chelan County, Washington: U.S. Geol. Survey Bull. 969-D, p. 87-103.

Lamey, C. A., and Hotz, P. E., 1952, The Cle Elum River nickeliferous iron ore deposits, Kittitas County, Washington: U.S. Geol. Survey Bull. 978-B, p. 27-67.

Lasky, S. G., 1949, National mineral resource appraisal: Min. Cong. Jour., v. 35, no. 1, p. 35-37.

Leith, C. K., 1903, The Mesabi iron-bearing district in Minnesota: U.S. Geol. Survey Mon. 43, 316 p.

Leith, C. K., and Harder, E. C., 1908, The iron ores of the Iron Springs district, southern Utah : U.S. Geol. Survey Bull. 338, 102 p.

Leith, C. K., Lund, R. J., and Leith, Andrew, 1935, Pre-Cambrian rocks of the Lake Superior region; a review of newly discovered geologic features with a revised geologic map: U.S. Geol. Survey Prof. Paper 184, 34 p.

Leith, Kenneth, and Liddell, D. M., 1936, Iron ore, in The mineral reserves of the United States and its capacity for production: Washington, Natl. Resources Comm., p. 97-123.

Leonard, B. F., 1951, Magnetite deposits of the St. Lawrence County district, New York: U.S. Geol. Survey open-file report, $22 \mathrm{p}$.

1952, Magnetite deposits and magnetic anomalies of the Brandy Brook and Silver Pond belts, St. Lawrence County, New York: U.S. Geol. Survey Mineral Inv. Map MF' 6.

- 1953, Magnetite deposits and magnetic anomalies at Spruce Mountain, St. Lawrence County, New York: U.S. Geol. Survey Mineral Inv. Map MF 10.

Lesure, F. G., 1957, Geology of the Clifton Forge iron district, Virginia : Virginia Polytech. Inst. Bull. v. 50, no. 7, 130 p.

Lewiecki, W. T., 1948, Georgia iron deposits, Cherokee, Bartow, Floyd, and Polk Counties, Part I : U.S. Bur. Mines Rept. Inv. 4178, 28 p. (For Part II, see Robertson, A. F., 1948.)

Lewis, Walter, 1951, Relationship of Cuyuna manganiferous resources to others in the United States, in Mining symposium-Geology of the Cuyuna range: Minneapolis, Minnesota Univ., Center for Continuation Study, p. 30-43.

Lloyd, C. L., Jr., 1954, How Sheffield's beneficiation plant upgrades Texas iron ores: Eng. Mining Jour., v. 155, no. 11, p. 98-100.

Lovering, T. S., 1929, The Rawlins, Shirley, and Seminoe iron-ore deposits, Carbon County, Wyoming: U.S. Geol. Survey Bull. 811-D, p. 203-235. 
Lowe, E. N., 1913, Preliminary report on iron ores of Mississippi: Mississippi Geol. Survey Bull. 10, 70 p.

Lynch, V. J., 1947, Andover-Sulphur Hill iron mines, Sussex County, New Jersey : U.S. Bur. Mines Rept. Inv. 4152, 12 p.

Mackin, J. H., 1947a, Iron ore deposits in the Clearwater district, Idaho County, Idaho: U.S. Geol. Survey open-file report, $20 \mathrm{p}$.

$1947 \mathrm{~b}$, Some structural features of the instrusions in the Iron Springs district: Utah Geol. Soc., Guidebook to the geology of Utah, no. 2, 62 p.

1953, Iron-ore deposits of the Iron Mountain district, Washington County, Idaho: U.S. Geol. Survey Bull. 982-E, p. 121-151.

1954, Geology and iron ore deposits of the Granite Mountain area, Iron County, Utah: U.S. Geol. Survey Mineral Inv. Map MF 14.

McCallie, S. W., 1900, A preliminary report on a part of the iron ores of Georgia : Georgia Geol. Survey Bull. 10-A, 190 p.

1908, Report on the fossil iron ores of Georgia: Georgia Geol. Survey Bull. 17, 199 p.

McMaster, P. D., 1946, Exploration of Chamberlain-Barnardville iron deposits, Roane County, Tennessee: U.S. Bur. Mines Rept. Inv. 3957, 19 p.

McMillan, W. D., 1946, Exploration of the Bourbon magnetic anomaly, Crawford County, Missouri : U.S. Bur. Mines Rept. Inv. 3961, 9 p.

Merritt, C. A., 1938, The magnetite deposits of the Wichita Mountains, Oklahoma: Oklahoma Acad. Sci. Proc. 1937, v. 18, p. 51-55.

1939, The iron ores of the Wichita Mountains, Oklahoma: Econ. Geology, v. 34, no. 3 , p. 268-286.

1940, Iron ores: Oklahoma Geol. Survey Mineral Rept. 4, 33 p.

Meyerhoff, H. A., 1933, Geology of Puerto Rico: San Juan, Puerto Rico Univ., Monograph, Ser. B, no. 1, 281 p.

1934, Iron in Puerto Rico: Revista de Obras Publicas de Puerto Rico, no. 3 , p. $595-597$; no. 5 , p. $635-636$; no. 8 , p. $704-710$.

1941, Mineral resources of the Greater Antilles: Mining and Metallurgy, v. 22, no. 413, p. 265-269.

Mikami, H. M., 1944, World iron-ore map : Econ. Geology, v. 39, no. 1, p. 1-24.

Millar, W. T., 1947, Investigation of magnetite deposits at Star Lake, St. Lawrence County, New York: U.S. Bur. Mines Rept. Inv. 4127, 14 p. (For supplement, see Reed, D. F., and Cohen, C. J., 1947.)

Millar, W. T., Hammond, H. O., and Sanford, R. S., 1949, Investigation of Red Back magnetite mine, Sterling Lake, Orange County, New York : U.S. Bur. Mines Rept. Inv. 4469, 4 p.

Miller, B. L., 1941, Mineral resources, in Lehigh County, Pennsylvania : Pennsylvania Geol. Survey, 4 th ser. Bull. C-39, p. 251-421.

Miller, R. L., 1945, Geology of the Katahdin pyrrhotite deposit and vicinity, Piscataquis County, Maine: Maine Géol. Survey Bull. 2, 21 p.

1947, Manganese deposits of Aroostook County, Maine: Maine Geol. Survey Bull. 4, $77 \mathrm{p}$.

Mining and Metallurgy, 1943, Adirondack iron mining issue, v. 24, no. 443, p. 475-525.

Mining Record, 1957, Great iron mining project in Wyoming may be sponsored by U.S. Steel Corp.: $\mathbf{v} .68$, no. 1, p. 7.

Mining World, 1953, Metallurgy is a mine maker (Jones and Laughlin's Star Lake, N.Y., martite plant) : v. 15, no. 7, p. 38-42.

Minnesota Interim Commission on Taxation of Iron Ore, 1955, Report of Legislative Commission on Taxation of Iron ore: St. Paul, Minn., $224 \mathrm{p}$. 
Monture, G. C., 1955, Techniques for the exploration and discovery of iron ore deposits, in Survey of world iron ore resources-Occurrence, appraisal and use: Dept. Econ. and Social Affairs, United Nations, United Nations Pub. Sales No. 1954.II.D.5, p. 77-105.

Morrison, G. A., and Grosh, W. A., 1950, Investigation of Oriskany iron-ore deposits, Alleghany, Bath, Botetourt, and Craig Counties, Virginia: U.S. Bur. Mines Rept. Inv. 4668, 59 p.

Muir, N. M., 1950, Investigation of the Rose Run iron area, Bath County, Kentucky : U.S. Bur. Mines Rept. Inv. 4650, $43 \mathrm{p}$.

Nason, F. L., 1922, The importance of the iron ores of the Adirondack region: Am. Iron and Steel Inst., $40 \mathrm{p}$.

Nelson, V. E., and Wood, E. B., 1949, Preliminary reports on iron resources of western Kentucky: Kentucky Geol. Survey Rept. Inv. No. 1, 7 p.

Neumann, G. L., 1947, Investigation of the Dillsburg magnetite deposits, York County, Pennsylvania : U.S. Bur. Mines Rept. Inv. 4145, 13 p.

Neumann, G. L., and Mosier, McHenry, 1948, Certain magnetite deposits in New Jersey: U.S. Bur. Mines Rept. Inv. 4225, 34 p. (For supplement, see Stampe, J. A., Mosier, McHenry, and others, 1949.)

Newhouse, W. H., and Hagner, A. F., 1951, Preliminary report on the titaniferous iron deposits of the Laramie Range, Wyoming: U.S. Geol. Survey open-file report, $48 \mathrm{p}$.

Newland, D. H., 1908, Geology of the Adirondack magnetic iron ores (with a report on the Mineville-Port Henry Mine, by J. F. Kemp) : New York State Mus. Bull. 119, 182 p.

Newland, D. H., and Hartnagle, C. A., 1908, Iron ores of the Clinton formation in New York State : New York State Mus. Bull. 123, 76 p.

Newton, Edmund, 1918, Manganiferous iron ores of the Cuyuna district, Minnesota : Minnesota Univ., Mines Exper. Sta. Bull, 5, 126 p.

New World Exploration Research and Development Corporation, 1952, Nevada mining's new look : Mining World, v. 14, no. 8, p. 26-29.

Oakeshott, G. B., 1948, Titaniferous iron-ore deposits of the western San Gabriel Mountains, Los Angeles County, California, pt. $\mathbf{P}$ of Iron Resources of California : California Dept. Nat. Resources, Div. Mines Bull. 129, p. 245-266.

Otte, H. F., 1943, Iron and titanium, in The expanding mineral industry of the Adirondacks : Albany, N.Y., State of New York Executive Dept., Div. Commerce Pub. 10, p. 11-51.

Pallister, H. D., and Burchard, E. F., 1953, Iron ore resources of the Southeast, in H. H. Chapman, W. M. Adamson, and others, The iron and steel industries of the South : University, Ala., Alabama Univ. Press, p. 34-52.

Pardee, F. G., 1948, Iron ore reserves in Michigan: Mining and Metallurgy, $v$. 29, no. 503, p. 613-614; also Michigan Conservation, v. 17, no. 9, p. 10-11.

Pardee, F. G., and Kennedy, B. E., 1948, Low-grade ore occurrences in Michigan : Minneapolis, Minnesota Univ., 9th Annual Mining Symposium, p. 16-24.

Park, C. F., Jr., 1947, What to do about our iron ore reserves: Mining and Metallurgy, v. 28, no. 484, p. 192-196.

Pennsylvania Department of Internal Affairs and The Pennsylvania State College, 1944, Pennsylvania's mineral heritage : Harrisburg, Pa., Commonwealth of Pennsylvania Dept. Int. Affairs, 248 p.

Penrose, R. A. F., Jr., 1892, The iron deposits of Arkansas: Arkansas Geol. Survey, Ann. Rept. 1892, v. 1, 153 p.

Percival, F. G., 1955, Nature and occurrence of iron ore deposits, in Survey of world iron ore resources-Occurrence, appraisal and use: Dept. Econ. and 
Social Affairs, United Nations, United Nations Pub. Sales No. 1954.II.D.5, p. $45-76$.

Perkins, J. M., and Lonsdale, J. T., 1955, Mineral resources of the Texas Coastal Plain (preliminary report): Texas Univ. Bur. Econ. Geology Rept: for Bur. of Reclamation, $49 \mathrm{p}$.

Pesonen, P. E., 1949, Investigation of the Waukon iron deposit; Allamakee County, Iowa : U.S. Bur. Mines Rept. Inv. 4479, 22 p.

Pettijohn, F. J., 1952, Geology of the northern Crystal Falls area, Iron County, Michigan : U.S. Geol. Survey Circ. 153, 17 p.

Pinnell, D. B., and.Marsh; J. A., 1954, Summary geological report on the titaniferous iron deposits of the Laramie Range, Albany County, Wyoming: Los Angeles, Union Pacific Railroad Co., 13 p.; also, Mines Mag., 1954, v. 44, no. 5, p. 31-33, 53, 56 .

Postel, A. W., 1952, Geology of Clinton County magnetite district, New York: U.S. Geol. Survey Prof. Paper 237, 88 p.

Powell, K. B., 1953, Eagle Mountain helps Kaiser meet growing western steel needs : Mining Eng. v. 5, no. 5, p. 479-483.

Price, P. H., 1929, Pocahontas County: West Virginia Geol. Survey County Repts., p. 313-319.

Price, P. H., Heck, E. T., Tilton, J. L., and Wells, Dana, 1939, Greenbrier County : West Virginia Geol. Survey, [County Report] 24, p. 665-672.

Quinn, A. W., 1945, Geology of the Plainfleld-Hawley area, Franklin and Hampshire Counties, Massachusetts, with special reference to deposits of manganese and iron minerals: U.S. Geol. Survey open-flle report, 38 p.

Randall, C. B., 1948, The iron we need: The Atlantic Monthly, no. 6, p. 60-64.

Reed, A. H., Jr., 1953, Investigation of red iron ore, Woodstock and Bucksville areas, Alabama : U.S. Bur. Mines Rept. Inv. 4981, 34 p.

Reed, D. F., 1949, Investigation of Talladega gray iron ores, Talladega County, Alabama : U.S. Bur. Mines Rept. Inv. 4426, 29 p.

Reed, D. F., and Cohen, C. J., 1947, Star Lake magnetite deposits, St. Lawrence County, New York: U.S. Bur. Mines Rept. Inv. 4131, 34 p. (Supplement to U.S. Bur. Mines Rept. Inv. 4127, by Millar, W. T., 1947.)

1949, Further investigations of the Redford-Clayburg magnetic district, Clinton County, New York: U.S. Bur. Mines Rept. Inv. 4447, 14 p. (Supplement to U.S. Bur. Mines Rept. Inv. 4003, by Bardill, J. D., 1947.)

Reed, G. C., 1949, Investigation of the Sheep Creek iron deposits, Meagher County, Montana : U.S. Bur. Mines Rept. Inv. 4400, 9 p.

Reeves, Frank, 1942, Summary of recent prospecting for manganese and iron ores in southeastern West Virginia: West Virginia Geol. Survey Bull. 6, $50 \mathrm{p}$.

Reeves, R. G., and Kral, V. E., 1955, Geology and iron ore deposits of the Buena Vișta Hills, Churchill and Pershing Counties, Nevada: Nevada Bur. Mines Bull. 53-A, 32 p.

Roberts, H. M., and Crago, W. H., 1948, Reserves and competitive position of Lake Superior iron ores: Minneapolis, Minnesota Univ., 9th Annual Mining Symposium, p. 1-15.

Robertson, A. F., 1946, Exploration of the Cherokee iron deposits, Cherokee County, North Carolina : U.S. Bur. Mines Rept. Inv. 3974, 31 p.

1948, Georgia iron deposits, Cherokee, Bartow, Floyd, and Polk Counties, Part II : U.S. Bur. Mines Rept. Inv. 4179, 42 p. (For Part I, see Lewiecki, W. T., 1948:) 
Robertson, E. C., 1956, Mägnetite deposits near Klukwan and Haines, southeastern Alaska : U.S. Geol. Survey open-file report, 37 p.

Roby, R. N., 1949, Investigation of Running Wolf iron deposits, Judith Basin County, Montana : U.S. Bur. Mines Rept. Inv. 4454, 7 p.

1950, Iron, in Mines and mineral deposits, Meagher County, Montana: U.S. Bur. Mines Ínf. Circ. 7540, p. 23-27, 33-34.

Roche, H. M., 1937, The iron ores of New Jersey : Iron Age, v. 139, no. 5, p. 74-80; no. 7, p. 39-43.

Ross, C. P., 1941, The metal and coal mining districts of Idaho, with notes on the nonmetallic mineral resources of the State; pt. 1; (and Carr. M. S.) annotated bibliography, pt: 2: Idaho Bur. Mines and Geology Pamph. 57, $263 \mathrm{p}$.

Royce, Stephen, 1936, Geology of the Lake Superior iron deposits : Lake Superior Mining Inst. Proc. v. 29, p. 68-107; also Min. Cong. Jour., v. 22, no. 3, p. 16-30, and 41.

1942, Iron ranges of the Lake Superior district, in Newhouse, W: H., ed., Ore deposits as related to structural features: Princeton, N. J., Princeton Univ. Press ; p. 54-63.

Sanford, R. S., and Stone, L. H., 1949, Investigation of Broughton and Ring magnetite deposits, Essex County, New York: U.S. Bur. Mines Rept. Inv. 4404, 4 p.

Schmidt, R. G., 1958, Bedrock geology of the southwestern part of the North Range; Cuyuna district, Minnesota : U.S. Geol. Survey Mineral Inv. map MF-181.

1959, Bedrock geology of the northern and eastern parts of the North Range, Cuyuna district; Minnesota: U.S. Geol. Survey Mineral Inv. map MF 182.

Schmidt, R. G., and Dutton, C. E., 1952, Progress report on geologic study of the Crosby and Ironton area of the Cuyuna range, Crow Wing County, Minnesota : U.S. Geol. Survey open-file report, 7 p.

- 1957, Bedrock geology of the south-central part of the North Range; Cuyuna district, Minnesota: U.S. Geol. Survey Mineral Inv. map MF-99.

Schwartz, G. M., 1951, Regional setting of the Cuyuna range, in Mining symposium-Geology of the Cuyuna range: Minneapolis, Minnesota Univ., Center for Continuation Study, p. 1-3.

1954, Mining geology of the Lake Superior district, in Fourth mining geology symposium : Minneàpolis, Minnesota-Univ., Center for Continuation Study, p. 1-2.

Severy, C. L., 1946, Exploration of the Minarets Iron deposit, Madera County, California : U.S. Bur. Mines Rept. Inv. 3985, 12 p.

- 1948, Mining methods at the Vulcan iron mine, San Bernardino County, California : U.S. Bur. Mines Inf. Circ. 7437, 11 p.

Shale, S. J., 1953, After two centuries of mining, Cornwall keeps its methods up-to-date: Mining Eng. v. 5, no. 7, p. 670-675.

Shannon, C. W., 1907, The iron ore deposits of Indiana: Indiana Dept. Geology and Nat. Resources, 31st Ann. Rept., p. 299-428.

Shattuck, J. R., and Ricker, Spangler, 1948, Shasta and California iron-ore deposits, Shasta County, California: U.S. Bur. Mines Rept. Inv. 4272, 11 p.

Shedd, Solon, Jenkins, O. P., and Cooper, H. H., 1922, Iron ores; fuels and fluxes of Washington: Washington Div. Geology Bull. 27, p. 1-115.

Sheridan, M. J., 1947, Lincoln County iron deposits, New Mexicö: U.S. Bur. Mines Rept. Inv. 3988, 19 p. 
Sims, P. K., 1953, Geology of the Dover magnetite district, Morris County, New Jersey : U.S. Geol. Survey Bull. 982-G, p. 245-305.

Sims, P. K., and Leonard, B. F., 1952, Geology of the Andover mining district, Sussex. County, New Jersey: New Jersey. Dept. Conserv, and Devel., Bull. 62,46 ;.

Singewald, J. T., Jr., 1911, Report on the iron ores of Maryland, with an account of the iron industry: Maryland Geol. Survey Spec. Pub. 9, p. 121-327.

1912, The iron ore deposits of the Cebolla district, Gunnison County, Colorado: Econ. Geology, v. 7, no. 6, p. 560-573. .

- 1913, The titaniferous iron ores in the United States; their composition and economic value: U.S. Bur. Mines Bull. 64, 145 p.

Skillings' Mining Review, 1955, Requirements and potential sources of iron ore for steel plants in U.S. for next 30 years : v. 44 , no. 28, p. $1,4$.

Smith, L. L., 1931, Magnetite deposits of French Creek, Pennsylvania : Pennsylvania Geol. Survey, 4th ser. Bull. M. 14, 52 p.

Smith, P. S., 1907, The gray.iron ores of Talladega County, Alabama: U.S. Geol. Survey Bull. 315, p. 161-184.

Soulé, J. H., 1947, Capitan iron deposits, Lincoln Connty, New Mexico: U.S. Bur. Mines Rept. Inv. 4022, 8 p., (For supplement, see Soulé, J. H., 1949,). 1949, Investigation of Capitan iron deposits, Lincoln County, New Mexico: U.S. Bur. Mines Rept. Inv. 4514, 5 p. (Supplement to U.S. Bur. Mines Rept. Inv. 4022, by Soulé, J. H., 1947.)

Spencer, A. C., 1908, Magnetite deposits of the Cornwall type in Pennsylvania: U:S. Geol. Survey Bull. 359, 102 p.

Stampe, J. A., Mosier, McHenry, and others, 1949, Magnetic surveys of certain magnetite deposits in New Jersey, Part II, Morris, Passaic, Sussex, and Warren Counties: U.S. Bur. Mines Rept. Inv. 4432, 8 p. (Supplement to U.S. Bur. Mines Rept. Inv. 4225, by Neumann, G. L., and Mosier, McHenry, 1948.)

Stauffer, C. R., and Thiel, G. A., 1944, The iron ores of sontheastern Minnesota : Econ. Geology, v. 39, no. 5, p. 327-339.

Stebinger, Eugene, 1914, Titaniferous magnetite beds on the Blackfeet Indian Reservation, Montana : U.S. Geol. Survey. Bull. 540, p. 329-337.

Stenzel, H. B., Fountain, H. C., and Kinney, D. M., 1948, Iron, in Geological resources of the Trinity River tributary area in Oklahoma and Texas: Texas Univ. Bur. Econ. Geology Pub. 4824; p. 185-193.

Stephenson, R. C., 1945, Titaniferous magnetite deposits of the Lake Sanford area, New York: New York State Mus. Bull. 340, 95 p.

Stewart, L. A., 1947, Apache iron deposit, Navajo County, Arizona: U.S. Bur. Mines Rept. Inv. 4093, $87 \mathrm{p}$.

Stone, J. B., 1934, Limonite deposits at the Orient mine, Colorado : Econ. Geology, v. 29, no. 4, p. 317-329.

Stout, W. E., 1944, The iron-ore bearing formations of Ohio: Ohio Geol. Survey, 4th Ser. Bull. 45, $230 \mathrm{p}$.

Stow, M. H., 1951, Iron, in The mineral resources and mineral industry of Virginia : Richmond, Va., Advisory Council on the Virginia Economy, Report of Committee on Mining, p. 50-52.

Sullivan, J. D., 1955, Beneficiating iron ore (North American practices), in Survey of world iron ore resources-Occurrence, appraisal and use : Dept. Econ. and Social Affairs, United Nations, United Nations Pub. Sales No. 1954.II.D.5, p. 106-121. 
Thoenen, J. R., Reed, A. H., Jr., and Clemmons, B: H., 1953, The future of Birmingham red iron ore, Jefferson County, Alabama: U.S. Bur. Mines Rept. Inv. 4988, $71 \mathrm{p}$.

Thoenen, J. R., and Warne, J. D., 1948, Alabama red iron ores, Greasy Cove and Shinbone Ridge, St. Clair and Etowah Counties: U.S. Bur. Mines Rept. Inv. $4243,35 \mathrm{p}$.

Thorne, R. L., and Wells, R. R., 1956, Studies of the Snettisham magnetite deposit, southeastern Alaska: U.S. Bur. Mines Rept. Inv. 5195, 41 p.

Tillinghast, E. S., 1948, New York's Benson Mines: Mining World; v. 10, no. 12, p. 27-30.

Trask, P. D., and Simons, F. S., 1945, Minarets magnetite deposits of Iron Mountain, Madera County, California, pt. I of Iron Resources of California : California Dept. Nat. Resources, Div. Mines Bull. 129, p. 119-128.

Troxell, J. R., 1948, Ahles iron mine, Warren County, New Jersey: U.S. Bur. Mines Rept. Inv. 4240, 8 p.

Umpleby, J. B., 1917, Manganiferous iron ore occurrences at Red Cliff, Colorado: Eng. Mining Jour., v. 104, no. 26, p. 1140-1141.

U.S. Bur. Mines Staff; Region!V, 1954, iIron, in Black Hills Mineral-Atlas, South Dakota, part 1 : U.S. Bur. Mines Inf. Circ: 7688, p. 98-100.

Van Hise, C. R., and Bayley, W. S., 1897, The Marquette iron-bearing district of Michigan (including a chapter on the Republic trough, by H. L. Smyth) : U.S. Geol. Survey Mon. 28, 608 p.

Van Hise, C. R., and Leith, C. K., 1911, The geology of the Lake Superior region: U.S. Geol. Survey Mon. 52, $641 \mathrm{p}$.

Vestal, F. E., 1951, Webster County iron ores: Mississippi Geol. Survey Bull. $73,48 \mathrm{p}$.

1954, Marshall County geology : Mississippi Geol. Survey Bull. 78, p. 164174.

Wade, H. H., and Alm. M. R. 1954, Mining directory of Minnesota : Minnesota Univ., Mines Exper. Sta. Bull., v. 57, no. 9, 274p.

Warner, A H., and Morrison, G. A., 1946, Exploration of the brown iron ores, Churchwell and Robinette tracts, Western Highland Rim district, Wayne County, Tennessee : U.S. Bur. Mines Rept. Inv. 3955, 18 p.

Warner, L. A., 1945, Iron deposits of the Mt. Andrew-Mamie area, southeastern Alaska : U. S. Geol.:Survéy pressirelease, $; 2$, p.

Warner, L. A., and Stefansson, K., 1945, Copper-bearing iron deposits at Tolstoi Mountain, Kasaan Peninsula, Prince of Wales Island, southeastern Alaska : U.S. Geol. Survey press release, 2 p.

Warner, L. A., and Walton, M. S., Jr., 1944, The Poor Man iron deposit, Kasaan Peninsula, Prince of Wales Island, southeastern Alaska: U.S. Geol. Survey prelim. rept., 7 p.

Warren, C. H., 1908, Contributions to the geology of Rhode Island; the petrography and mineralogy of Iron Hill Mine, Cumberland: Am. Jour. Sci., 4th ser., v. 25, p. 12-38.

Washington Division of Mines and Mining, 1940, Summary of information on iron ore deposits of Washington : Inf. Circ. 6, 11 p.

Weidman, Samuel, 1904, The Baraboo iron-bearing district of Wisconsin: Wisconsin Geol. Survey Bull. 13, Econ. Ser. 8, 190 p. 
Wells, F. G., 1938, The origin of the iron ore deposits in the Bull Valley and Iron Springs district, Utah : Econ. Geology, v. 33, no. 5, p. 477-507.

Wells, R. R., and Thorne, R. L., 1953, Concentration of Klukwan, Alaska, magnetite ore : U.S. Bur. Mines Rept. Inv. 4984, 15 p.

Westgate, L. G., 1920, Deposits of iron ore near Stanford, Montana : U.S. Geol. Survey Bull. 715-F, p. 85-92.

White, C. M., 1947, Iron ore and the steel industry, in Seventy-five years of progress in the mineral industry, 1871-1946: New York, Am. Inst. Mining Metall. Engineers, p. 559-586.

White, D. A., 1954, The stratigraphy and structure of the Mesabi range, Minnesota : Minnesota Geol. Survey Bull. 38, 92 p.

White, W. S., 1943, Occurrence of manganese in eastern Aroostook County, Maine: U.S. Geol. Survey Bull. 940-E, p. 125-161.

Wiebelt, F. J., 1947, Bessemer iron project, San Bernardino County, California : U. S. Bur. Mines Rept. Inv. 4066, 13 p.

Wiebelt, F. J., and Ricker, Spangler, 1948, Iron Mountain deposits, San Bernardino County, California : U.S. Bur. Mines Rept. Inv. 4236, 11 p.

Wier, K. L., Balsley, J. R., and Pratt, W. P, 1953, Aeromagnetic survey of part of Dickinson County; Michigan,-. with preliminary geologic interpretation: U.S. Geol. Survey Geophys. Inv. Map GP-115.

Williams, A. J., 1935, Hematite in the Reagan sandstone along the northeastern edge of the Wichita Mountains and in the Arbuckle Mountains: Oklahoma Acad. Sci. Proc. 1934, v. 15, p. 81-82.

Wimmler, N. L., 1946, Exploration of Choteau titaniferous magnetite deposit, Teton County, Montana: U.S. Bur. Mines Rept. Inv. 3981, 12 p.

1946, Exploration of Southern Cross iron deposits, Deer Lodge County, Montana : U.S. Bur. Mines Rept. Inv. 3979, 14 p.

Wolff, J. F., Sr., 1951, The geologic stratigraphy and correlation of the Cuyuna iron district, Minnesota, in Mining symposium-Geology of the Cuyuna range: Minneapolis, Minnesota Univ., Center for Continuation Study, p. 4-29.

Wright, L. A., Stewart, R. M., Gay, T. E., Jr., and Hazenbush, G. C., 1953, Mines and mineral deposits of San Bernardino County, California: California Jour. Mines and Geology, v. 49, nos. 1 and 2, p. 49-100.

Wright, R. J., and Raman, N. D., 1948, The Gossan Lead, Carroll County, Virginia : U.S. Geol. Survey open-file report, 21 p.

Wright, W. S., and Fosse, E. L., 1946, Exploration of the Jumbo Basin iron deposit, Prince of Wales Island, southeastern Alaska: U.S. Bur. Mines Rept. Inv. 3952, 9 p.

Wright, W. S., and Tolonen, A. W., 1947, Mount Andrew iron deposit, Kasaan Peninsula, Prince of Wales Island, southeastern Alaska: U.S. Bur. Mines Rept. Inv. 4129, $27 \mathrm{p}$.

Young, W. E., 1947, Iron deposits, Iron County, Utah; U.S. Bur. Mines Rept. Inv. 4076, 102 p. (For Supplement, see Allsman, P. T., 1948.)

Zapffe, Carl, 1933, The Cuyuna iron ore district, the Lake Superior region, in Lake Superior region: Internat. Geol. Cong., 16th, United States, 1933, Guidebook 27, p. 72-78.

1944, Memorandum report on iron ores of the Cle Elum district, Washington: Washington Div. Mines and Mining Dept. Inv. 5, 27 p.

1945, Hamilton iron-bearing lenses on Iron Mountain, Skagit County, Washington: Mining World, v. 7, no. 11, p. 25-29. 
Zapffe, Carl, 1949, A review, iron bearing deposits in Washington, Oregon and Idaho: Portland, Oreg., Raw Materials Survey, Inc., Resources Rept. 5, 89 p.

Zinner, Paul, and Holmberg, C. L., 1947, Investigation of the iron-bearing formation of the western Gogebic range, Iron County, Wisconsin: U.S. Bur. Mines Rept. Inv. 4155, $48 \mathrm{p}$.

Zoldok, s. W., 1948, Cle Elum iron-nickel deposits, Kittitas County, Washington : U.S. Bur. Mines. Rept. Inv. 4189, 8 p.

Zoldok, S. W., Cole, J. W., and Dougherty, E. Y., 1947, Iron deposits of Buckhorn Mountain, Mejers Creek mining district, Okanogan County, Washing- . ton : U.S. Bur. Mines Rept. Inv. 4051; 22 p.

Zoldok, S. W., and Wilson, S. R., 1953, Bull Valley iron-ore deposits, Washington County, Utah: U.S. Bur. Mines Rept. Inv. 4948, 17 p.

\section{GEOGRAPHIC INDEX TO SELECTED BIBLIOGRAPHY}

\section{General :}

United States:

Blondel, Fernand, and Lasky, S. G., 1955

Burchard, E. F., 1933

Burchard, E. F., Johnson, A. C., and Melcher, N. B., 1947

Carr, M. S., and Pesonen, P. E., 1952.

Davis, E. W., 1950

Dutton, C. E., 1952, 1955

Eckel, E. C., 1914

Forbes, J. M., 1956

Gruner, J. W., 1950

Hart, Charles, 1939

Hayes, C. W., 1909

Johnston, V. D., 1955

Julihn, C. E., and Moon, L. B., 1945

Killeen, P. L., Carr, M. S., and Flint, D. E., 1952

Lasky, S. G., 1949

Leith, Kenneth, and Liddell, D. M., 1936

Mikami, H. M., 1944

Monture, G. C., 1955

Park, C. F., Jr., 1947

Percival, F. G., 1955

Randall, C. B., 1948

Singewald, J. T., Jr., 1913

Skillings' Mining Review, 1955

Sullivan, J. D., 1955

White, C. M., 1947

Lake Superior region:

Crowell \& Murray, Inc., 1930

Davis, E. W., 1947

Hotchkiss, W. O., and others, 1933
Lake Superior Iron Ore Association, 1938, 1952

Leith, C. K., Lund, R. J., and Leith, Andrew, 1935

Roberts, H. M., and Crago, W. H., 1948

Royce, Stephen, 1936, 1942

Schwartz, G. M., 1954

Van Hise, C. R., and Leith, C. K., 1911

Southeastern region :

Pallister, H. D., and Burchard, E. F., 1953

Western region:

Bacon, W. R., 1954

Bain, H. F., 1945

Dutton, C. E., and Carr, M. S., 1947

Hodge, E: T., 1935-38

Alabama :

Brown, Andrew, 1948

Burchard, E. F., 1907, 1909, 1914, 1932, 1938

Burchard, E. F., and Andrews, T. G., 1947

Burchard, E. F., and Butts, Charles, 1910

Pallister, H. D., and Burchard, E. F., 1953

Reed, A. H., Jr., 1953

Reed, D. F., 1949

Smith, P. S., 1907

Thoenen, J. R., and Warne, J. D., 1948

Thoenen, J. R., Reed, A. H., Jr., and Clemmons, B. H., 1953 
Alaska :

Buddington, A. F., and Chapin, Theodore, 1929

Dutton, C. E., 1955

Eakin, H. M., 1915

Erickson, A. W., 1948

Goddard, E. N., Warner, L. A., and Walton, M. S., Jr., 1944

Grantz, Arthur, 1956

Holt, 'S. P., and Sanford, R. S., 1946

Kennedy; G. C., 1953

Killeen, P. L., 1952

Robertson, E. C., 1956

Thorne, R. L., and Wells, R. R., 1956

Warner, L. A., 1945

Warner, L. A., and Stefansson, K., 1945

Warner, L. A., and Walton, M. S., Jr., 1944

Wells, R. R., and Thorne, R. L., 1953

Wright, W. S., and Fosse, E. L., 1946

Wright, W. S., and Tolonen, A. W., 1947

Arizona :

Burchard, E. F., 1931

Cummings, J. B., 1946

Farnham, L. L., and Havens, R., 1957

$\therefore \quad$ Stewart, L. A., 1947

Arkansas :

Brown, W. F., 1953

Penrose, R. A. F.; Jr., 1892

California :

Burchard, E. F., 1948

Durrell, Cordell, and Proctor, P. D., 1948

Hadley, J. B., 1945

Hewett, D. F., 1948

Johnson, A. C., and Ricker, Spangler, 1948

Lamey, C. A., 1945

Oakeshott, G. B., 1948

Powell, K. B., 1953

Severy, C. L., 1946, 1948

Shattuck, J. R., and Ricker, Spang. ler, 1948

Trask, P. D., and Simons, F. S., 1945

Wiebelt, F. J., 1947
Wiebelt, F. J., and Ricker, Spangler, 1948

Wright, L. A., Stewart, R. M., Gay, T. E., Jr., and Hazenbush, G. C., 1953

Colorado:

Behre, C. H., Jr., Osborn, H. F., and Rainwater, E. H., 1936

Harder, E. C., 1909

Singewald, J. T., Jr., 1912

Stone, J. B., 1934

Umpleby, J. B., 1917

Connecticut :

Eckel, E. C., 1905

Hobbs, W. H., 1907

Keith, H. C., and Harte, C. R., 1935

Georgia :

Burchard, E. F., 1909, 1914

Furcron, A. S., and Ray, D. L., 1957

Haseltine, R. H., 1924

Kesler, T. L., 1950

Lewiecki, W. T., 1948

McCallie, S. W., 1900, 1908

Pallister, H. D., and Burchard, E. F., 1953

Robertson, A. F., 1948

Idaho:

Mackin, J. H., 1947a, 1953

Ross, C. P., 1941

Zapffe, Carl, 1949

Indiana :

Fix, G. F., 1938

Shannon, C. W., 1907

Iowa :

Howell, J. V., 1916

Pesonen, P. E.; 1949

Kentucky :

Crouse, C. S., and Wyatt, J. L., 1948

Muir, N. M., 1950

Nelson, V. E., and Wood, E. B., 1949

Louisiana :

Burchard, E. F., 1915

Maine :

Eilertsen, N. A., 1952

Miller, R. L., 1945, 1947

White, W. S., 1943

Maryland :

Singewald, J. T., Jr., 1911 
Massachusetts :

Burgess, R. J., and Sanford, R. S., 1949

Chute, N. E., 1945

Crosby, I. B., 1932

Eckel, E. C., 1905

Hobbs, W. H., 1907

Quinn; A. W., 1945

Michigan :

Bayley, W. S., 1904

Boyum, B. H., 1954

Clements, J. M., and Smyth, H. L., 1899

Irving, R. D., and Van Hise, C. R., 1892

James, H. L., 1954

James, H. L., and Dutton, C. E., 1951

Pardee, F. G., 1948

Pardee, F. G., and Kennedy, B. E., 1948

Pettijohn, F. J., 1952

Van Hise, C. R., and Bayley, W. S., 1897

Wade, H. H., and Alm, M. R., 1954

Wier, K. L., Balsley, J. R., and Pratt, W. P., 1953

Minnesota :

Brown, D. I., 1953

Clements, J. M., 1903

Emmons, W. H., and Grout, F. F., 1943

Grout, F. F., 1926, 1949-1950

Grout, F. F., and Broderick, T. M., 1919

Grout, F. F., and Wolff, J. F., Sr., 1955

Gruner,.J. W., 1946, 1954

Harder, B. C., 1917, 1918

Leith, C. K., 1903

Lewis, Walter, 1951

Minnesota, Interim Commission on Taxation of Iron Ore, 1955

Newton, Edmund, 1918

Schmidt, R. G., 1958, 1959

Schmidt, R. G., and Dutton, C. E., 1952, 1957

Schwartz, G. M., 1951

Stauffer, C. R., and Thiel, G. A., 1944

Wade, H. H., and Alm, M. R., 1954
White, D. A., 1954

Wolff, J. F., Sr., 1951

Zapffe, Carl, 1933

Mississippi :

Attaya, J. S., 1952

Lowe, E. N., 1913

Vestal, F. E.; 1951, 1954

Missouri :

Ballinger, H. J., and Pesonen, $\cdot \mathbf{P a}$ l, 1948

Bishop, O. M., 1952

Clark, E. L., and Muilenburg, G. A.; 1954

Crane, G. W., 1912

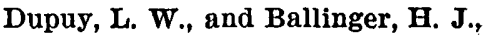
1949

Engineering and Mining Journal, 1957.

Hayes, W. C., 1857

Kreamalmyer, K. L., 1945

Lake, M. C., 1932

McMillan, W. D., 1946

Montana :

DeMunck, V. C., 1956

Freeman, V. L., 1954

Goodspeed, G. E., 1946, a, b, c, d

Reed, G. C., 1949

Roby, R. N., 1949, 1950

Stebinger, Eugene, 1914

Westgate, L. G., 1920

Wimmler, N. L., 1946

Nevada :

Butler, A. P., Jr., 1945

Geehan, R. W., 1949

Jones, J. C., 1913

Kral, V.. E., 1947

New World Exploration Research and Development Corporation, 1952

Reeves, R. G., and Kral, V. E., 1955

New Jersey :

Bayley, W. S., 1910

Botsford, G. B., and Mosier, McHenry, 1948

Hawkes, H. E., Jr., and Hotz, P. E., 1947

Hotz, P. E., 1953, 1954

Lynch, V. J., 1947

Neumann, G. L., and Mosier, McHenry, 1948

Roche, H. M., 1937

Sims, P. K., 1953 
Sims, P. K., and Leonard, B. F., Ohio: 1952

Stampe, J. A., Mosier, McHenry, and others, 1949

Troxell, J. R., 1948

New'Mexico :

Entwistle, L. P., 1944

Grantham, R. M., and Soulé, J. H., 1947

Joesting, H. R., Bacon, L. O., and Getz, J. H., 1948 .

Kelley, V. C., 1949, 1951

Sheridan, M. J., 1947

Soulé, J. H., 1947, 1949

New York :

American Metal Market, 1955

Balsley, J. R., Jr., 1943

Bardill, J. D., 1947, a, b, c

Buddington, A. F., and Leonard, B. F.; 1949

Colony, R. J., 1923

Eckel, E. C., 1905

Gillette, Tracy, 1947

Hawkes, H. E., Jr., and Hotz, P. E., 1947

Hobbs, W. H.; 1907

Hotz, P. E., 1953b

Leonard, B. F., 1951, 1952, 1953

Millar, W. T., 1947

Millar, W. T., Hammond, H. O., and Sanford, R. S., 1949

Mining and Metallurgy, 1943

Mining World, 1953

Nason, F. L., 1922

Newland, D. H., 1908

Newland, D. H., and Hartnagle, C. A., 1908

Otte, H. F., 1943

Postel, A. W., 1952

Reed, D. F., and Cohen, C. J., 1947, 1949

Sanford, R. S., and Stone, L. H., 1949

Stephenson, R. C., 1945

Tillinghast, E. S., 1948

\section{North Carolina :}

Bayley, W. S., 1922, 1923, 1925

Goldich, S. S., and Wedow, Helmuth, Jr., 1943

Kline, M. H., and Ballard, T. J., 1948

Robertson, A. F., 1946

Bengston, R. G., Moore, D. D., Ramsey, R. H., and Lund, R. J., 1950

Ireland, H. A., 1944

Stout, W. E., 1944 .

Oklahoma :

Chase, G. W., 1950, 1952

Merritt, C. A., 1938, 1939, 1940

Stenzel, H. B., Fountain, H. C., and Kinney, D. M., 1948

Weissenborn, A. E., and 'Stenzel, H. B., 1948

Williams, A. J., 1935

Oregon :

Hodge, E. T., 1935

Hotz, P. E., 1953a

Kelly, J. V., 1947

Zapffe, Carl, 1949

Pennsylvania :

Butts, Charles, and Moore, E. S., 1936

Cumings, W. L., 1932

Foose, R. M., 1945

Hawkes, .H. E., Jr., Wedow, Helmuth, and Balsley, J. R., 1953

Hickok, W. O., IV, 1933, 1939

Hotz, P. E., 1950

Knoerr, A. W., 1953

Miller, B. L., 1941

Neumann, G. L., 1947

Pennsylvania Department of Internal Affairs and The Pennsylvania State College, 1944

Shale, S. J., 1953

Smith, L. L., 1931

Spencer, A. C., 1908

Puerto Rico:

Carr, M. S., 1952

Colony, R. J., and Meyerhoff, H. A., 1935

Dutton, C. E., 1955

Fettke, C. R., and Hubbard, Bela, 1920

Knoerr, A. W., 1952

Meyerhoff, H. A., 1933, 1934, 1941

Rhode Island :

Johnson, B. L., 1908

Warren, C. H., 1908

South Dakota :

Connolly, J. P., and O'Harra, O. O., 1929 
Cooledge, C. W., and Orerspeck, L. S., 1909

U.S. Bur. Mines Staff, Region V, 1954

Tennessee:

Bayley, W. S., 1923

Burchard E. F., 1909, 1913, 1914, 1934,1941

Goldich, S. S., and Wedow, Helmuth, Jr., 1943

Kline, M. H., and Ballard, T. J., 1948

McMaster, P. D., 1946

Pallister, H. D., and Burchard, E. F., 1953

Warner, A. H., and Morrison, G. A., 1946

Texas:

Barnes, V. E., Goldich, S. S.; and Romberg, Frederick, 1949

Dutton, C. E., and Carr, M. S., 1947

Eckel, E. B., 1938

Evans, A. M., 1947

Evans, A. M., and Soulé, J. H., 1947

Lloyd, C. L., Jr., 1954

Perkins, J. M., and Lonsdale, J. T., 1955

Stenzel, H. B., Fountain, H. C., and Kinney, D. M., 1948

\section{Utah :}

Allsman, P. T., 1948

Cook, K. L., 1950

Crawford, A. L., and Buranek, A. M., 1952

Leith, C. K., and Harder, E. C., 1908

Mackin, J. H., 1947b, 1954

Wells; F. G., 1938

Young, W. E., 1947

Zoldok, S. W., and Wilson, S. R., 1953

Virginia :

Boyd, C. R., 1897

Eby, J. B., 1923

Eckel, E. C., 1906

Espenshade, G. H., 1952

Furcron, A. S., 1935

Gooch, E. O., 1954

Harder, E. C., 1909a
Holden, R. J., 1906, 1907, 1933

Kline, M. H., and Ballard, T. J., 1949

Lesure, F. G., 1957

Morrison, G. A., and Grosh, W. A., 1950

Stow, M. H., 1951

Wright, R. J., and Raman, N. D., 1948

Washington :

Broughton, W. A., 1943, 1944, 1945

Glover, S. L., 1942

Kelly, J. V., 1947

Lamey, C. A., 1950

Lamey, C. A., and Hotz, P. E., 1952

Shedd, Solon, Jenkins, O. P., and Cooper, H. H., 1922

Washington Div. Mines and Mining, .1940

Zapffe, Carl, 1944, 1945, 1949

Zoldok, S. W., 1948

Zoldok, S. W., Cole, J. W., and Dougherty, E. Y., 1947

West Virginia:

Grimsley, G. P., 1909

Price, P. H., 1929

Price, P. H., Heck, E. T., Tilton, J. L., and Wells, Dana, 1939

Reeves, Frank, 1942

Wisconsin:

Aldrich, H. R., 1929

Bean, E. F., 1949

Irving, R. D., and Van Hise, C. R., 1892

Wade, H. H., and Alm, M. R., 1954

Weidman, Samuel, 1904

- Zinner,.Paul, and Holmberg, C. L., 1947

Wyoming :

Ball, S. H., 1907

Diemer, R. A., 1941

Frey, Eugene, 1946a, b, 1947a, b

Hild, J. H., 1953

Lovering, T. S., 1929

Mining Record, 1957

Newhouse, W. H., and Hagner, A. F., 1951

Pinnell, D. B., and Marsh, J. A., 1954 



\section{INDEX}

[See also alphabetical list of iron deposiț, p. 103-109 and geographic Index to selected bibliography, p. 127-131]

Page Page

Alabama, Birmingham district... 66, 67, 71, 73-74, 90 history of production. resources by area. .......................... 90-91 Russellville district...-............. 71, 74, 81, 90 Alaska, Haines-Klukwan deposit.......... 80-81, 102 Prince of Wales Island deposits.......... 80, 102 resources................................... 87, 102 Snettisham deposits...................... 81, 102 Alumina, impurity ........................... 69, 81 Artzona, resources by area.................... $\quad 97$ Arkansas, resources by area................... 95

Bedded deposits.................................. 71

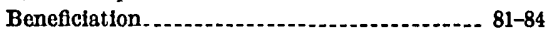

Bessemer and nonbessemer ore, defined....... 82

Bibliography................................. 110-126

California, Eagle Mountains deposits.......... 79,97 history of production. ................... 67

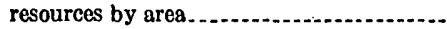

Cavity-fllling deposits.

Central and gulf region, deficlency In potential ore. defined.

principal deposits production 78-78 resources.................... 64, 65, 87, 95-96, pl. 2 $64,65,67, \mathrm{pl} .2$

Ohalcopyrite, Impurity.

Ohemical composition, direct-shipping ore and concentrates. 73,80 principal iron-ore minorals.

Ohromium impurity

Coal, source 69,81

Cobalt, impurity ....................................

Colorado, resources by area

Concentrates, chemical composition........... dexined. preparation.................................. production

Oonsumption

Magnetite, Alaska.

described

Lake Superior region. ..................... 75

$\therefore$ northeastern reglon........................ 72,73

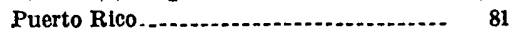

western region............. 79

Magnetite-llmenite, Alaska................... $\quad 80$

Direct-shipping ore, defined................... 63, 82

Georgia, deposits

Gold, byproduct.............................. 73,80

Gulf region. See Central and gulf region.

Hematite, central and gulf reglon........... 78 described................................... 68 Lake Superior reglon.................... 75, 76, 77 northeastern region........................ 72, 73

Puerto Rico......................................

southeastern region. western region.

Manganese, impurity

Maryland, resources by area............... 92

Michigan, Gogeble range................ 74, 76-77, 94 history of production. .................... 67 Marquette range................. 67, 74, 77-78, 94 Menominee range .................. 74, 77, 94, 95 resources by area........................... 94

Mines and deposits, alphabetical list....... 103-109 See also particular State or region.

Minnesota, Cuyuna range............... 67, 74, 76, 94 history of production.................. 67 Mesabl range........................... 66, 67, 74, 75-76, 83-84, 94-95, pl. 2 resources by area........................... 94-95 Vermilion range.................... 67, 74, 75, 95 
Mississippi, resources by area...............

Missouri, history of production.

Iron Mountain deposits. resources by area.

Montana, resources by area.

Nevada, resources by area.

New England, early mining and smelting ....

New Jersey Dover district highlands area......................... 73

history of production . .

resources by area. 88

New Mexico, resources by area.............. 99

New York, Adirondack district.......... 67, 71, 72

Benson mines................. 72,88

history of production.................. 67

Lake Sanford deposit................ 71

Lyon Mountain.............. 72,89

Mineville-Port Henry 72.89

resources by ares. .

Nickel, impurity

North Carolina, resources by area........... 93

Northeastern region, defined............... 63 princlpal deposits

$64,65,67, \mathrm{pl} .2$

production $65,87,88-92$, pl: 2

Ohlo, resourcès by area

Oklahoma, resources by area.

Open-pit mining $-2, \ldots . . .0$

Oregon, resources by area $72,73,75,76,77,78,79,8$

Pennsylvania, Cornwall deposit. $67,71,73.89$ deposits ............. 67, 71, 73 Grace mine........ 73.89 bistory of production. . resources by area.

Phosphorus....................... 69, 82

Potential ore, amount and location. See particular State, resources by area. defined. $63-64,65,66-67$, pl. 2

Production of iron ore See also particular State or region.

Puerto Rico, Jancos deposit..._._. . . . ..... 81, 102 Mayagüez Mesa. . . resources 86,102

Replacement deposits

Reserves, defined

8,85

size and location. See particular State, resources by area.

Residual deposits
Resources, classification..................... 84

deflned.................. 84

estimates............... pl.

tabulation................. 85-102

Rhode Island, resources by area.

Segregation deposits...................... 71

Siderite, described....... 68

northeastern region................. 72

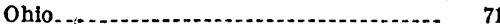

Pennsylvania:_..._._.

Texas. . . . .

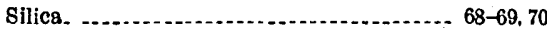

Silver, byproduct................. 73,80

Smelting centers, location.

South Dakota, resources by area............. 96

Southeastern regton, defined.................. 63

principal iron-ore deposits. . . . . . . . . 73-74 production............. $64,65,67, \mathrm{pl} .2$ resources. ................... 64,65,87, 92-94, pl. 2

Steel industry. See Iron and steel industry.

Sulfur, Impurity

Taconite, beneficiation. . . . . . . . . . . . . 83-84 defined............. 76

Tennessee, resources by area.............. 93

Texas, deposits. history of production.:_..... 67 resources by area. . .

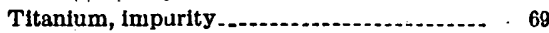

Underground mining...... 72, 73, 74, 75, 76, 79, 81-82

United States, summary of iron-ore resources. $\quad 87$ See also particular State, resources by area.

Utah, Iron Springs district.................. 79 resources by area............... 99

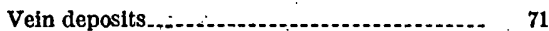

Virginia, early mining and smelting ....... 66 resources by area....................... 93

Washington, resources by area.............. 99

West Virginia, resources by area................ 94

Western region, deficiency in potential ore...... 64

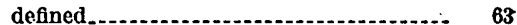
principa] deposits......... 79-80 production................. 64,65,67, pl. 2 resources. . . .

Wisconsin, Gogebic range........... 74, 76-77 history of production. 67 Menominee range.............. 74, 77, 94, 95 resources by area. ...................... 95

Wyoming, Hartville distriet............. 79-80, 100 history of production. ........... 67 resources by area. ........ 100 